

\section{White Paper on Nordic Sustainable Cities}

ISBN: 978-91-87295-69-0

ISSN: 1403-2503

DOI: http://doi.org/10.30689/R2017:3.1403-2503

(C) Nordregio 2017 and the authors

Borges, L. A.; Nilsson, K.; Tunström, M.; Dis, A. T.; Perjo, L.; Berlina, A.; Costa, S. O.; Fredricsson, C.; Grunfelder, J.; Johnsen, I.; Kristensen, I.; Randall, L.;

Smas, L.; Weber, R. (2017)

Available online at: http://www.nordregio.org/publications/white-paperon-nordic-sustainable-cities/

Nordic Co-operation is one of the world's most extensive forms of regional collaboration, involving Denmark, Finland, Iceland, Norway, Sweden, the Faroe Islands, Greenland and Åland. Nordic co-operation has firm traditions in politics, the economy and culture. It plays an important role in European and international collaboration, and aims at creating a strong Nordic community in a strong Europe. Nordic co-operation seeks to safeguard Nordic and regional interests and principles in the global community. Common Nordic values help the region solidify its position as one of the world's most innovative and competitive.

Nordregio is a leading Nordic and European research centre for regional development and planning, established by the Nordic Council of Ministers. We conduct solution-oriented and applied research, addressing current issues from both a research perspective and the viewpoint of policymakers and practitioners.

Stockholm, Sweden 2017 


\section{Preface}

'Nordic Sustainable Cities' is one of six flagship projects within Nordic Solutions to Global Challenges, an initiative launched by the Nordic prime ministers.

As the Nordic urban model is founded on the values of environment, equality, openness and efficiency, the initiative should contribute to spreading Nordic approaches to good and sustainable urban development across the world. Nordic Sustainable Cities directly links to the United Nations' Sustainable Development Goal (SDG) 11: Make cities inclusive, safe, resilient and sustainable. It also contributes to other SDGs, such as 3: Ensure healthy lives and promote well-being, 5: Achieve gender equality, 6: Ensure access to water and sanitation, and 13: Take urgent action to combat climate change and its effects.

By $2050,66 \%$ of the world's population is expected to live in urban conurbations. The World Resources Institute has estimated that, between 1995 and 2030, cities in Asia, Africa and Latin America will account for $90 \%$ of an estimated global population growth of 2.7 billion. Urbanization is thus a worldwide phenomenon. From a global perspective, one of the biggest challenges is to create a sustainable and inclusive environment for the growing urban population.

While cities are strong drivers of economic growth, they do experience several problems, such as crime, housing shortage, youth unemployment and segregation, while also having substantial climatic and environmental impacts.

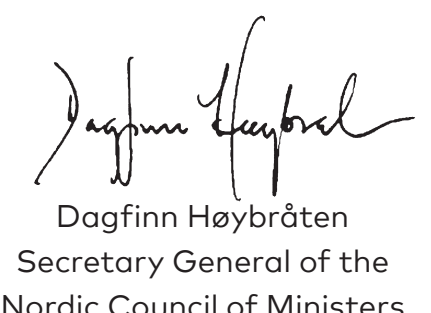

Urbanization accelerated about 100 years ago in Europe and North America, but significantly less intensely than in the present day. During the latter part of this development phase, after the Second World War, the Nordic Region became a model for urban planning. Professionals and politicians from all over the world came to Vällingby, Albertslund and Tapiola to study how suburbs could develop as modern urban forms supporting a high quality of life.

Continuously pursuing ways to address contemporary challenges, the Nordic urban model remains highly appreciated internationally. The Nordic Region offers high-quality urban solutions based on strengths such as good governance, public-private partnerships, design tradition, environmental and social consciousness, and robust technological solutions. Even in the development of small and medium-sized cities and in the interplay between town and countryside, the Nordic Region can be an example to the world.

The aim of Nordic Sustainable Cities is to strengthen the Nordic brand, add value to existing trade promotion efforts, through Nordic co-operation, and expand the market potential of Nordic businesses. The project, which is co-ordinated by Nordic Innovation, is carried out in close co-operation with national export organisations, clusters and businesses. The current White paper, developed by Nordregio, presents the background story supporting inclusive, safe and sustainable Nordic cities.

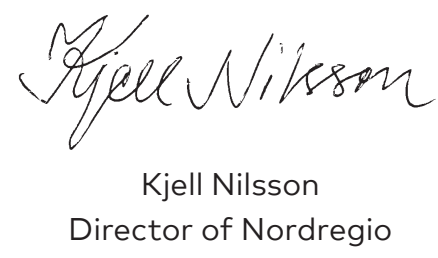




\section{Scope}

This white paper tells the story of Nordic Sustainable Cities. This story relies on shared norms and values and on a set of initiatives, policies, tools and instruments identified in cities of the Nordic Region that may offer solutions for sustainable futures. Beginning with these values and tools, a set of 'practices' are acknowledged and brought together to highlight certain features to show what a sustainable city might be from a Nordic perspective.

This story brings together practitioners, public authorities and private actors in a common narrative with a twofold aim. First, common knowledge is formed, in which competences from various sectors are acknowledged and allow actors to make sense of their roles and opportunities for action on sustainable urban solutions. Second, such a narrative creates space for communication and negotiation, facilitating learning and encouraging synergies between actors from different sectors searching for and implementing sustainable urban solutions. As a platform for the range of Nordic solutions for sustainable cities, this story invites stakeholders to discuss and develop ideas about the feasibility of implementing these solutions in diverse contexts.

The added value of a common story that transcends national boundaries is based on the belief that the Nordic countries are stronger together. They combine a range of competences that offer valuable solutions for sustainable cities in regard to energy, transport and buildings. In addition, this story reinforces the perception that other countries outside Europe have about the Nordic countries, which places Swedes, Danes, Finns, Icelanders and Norwegians under the common label of 'Nordic'. By realizing their potentialities and exploring their possibilities and opportunities for joint action, the Nordic countries are expected to engage in discussions with other cities in the world. These cities can adapt Nordic solutions that may inspire alternatives or solutions to address some of the challenges outlined in the 17 Sustainable Development Goals (SDGs) identified in the Agenda for Sustainable Development (UN, 2015), especially goal number 11: 'Make cities inclusive, safe, resilient and sustainable'.

This is a positive story that focuses on good practices and examples from the Nordic Region. Nevertheless, dealing with the complexity and disputes that surround the term 'sustainability' while maintaining the necessarily high level of generalization to create the overall framework has been a major challenge in writing the story. In this respect, the term 'sustainability' is understood to refer to practices that to some extent respond to environmental, social and economic challenges. However, this perspective disregards how equally these three sustainability aspects have been achieved in a certain initiative or project. Nor does it consider the consumption perspectives that certainly influence overall sustainability. This study highlights some good Nordic projects or initiatives to inspire other countries without claiming to be the one and only model of sustainability.

Despite these challenges, many lessons were learnt in the process of writing this story. The discussions of the contents in a range of forums have been enlightening with respect to how it could be interpreted and used in various contexts. These debates have also contributed to reshaping some of the content and to understanding the future direction of Nordic sustainable urban development. In this respect, we extend our sincere thanks to all other co-authors of this story-interviewees and participants in the focus groups, the Nordic City Network (NCN), the Nordic Built City Jury (see Appendix 1), the participants in the workshops held in Stockholm, Copenhagen, Oslo and Helsinki and our colleagues at Nordic Innovation -for sharing their opinion and perspectives.

1 [UN] United Nations (2015). Transforming our world: the 2030 


\section{Contents}

Preface

Scope

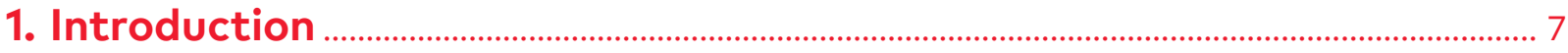

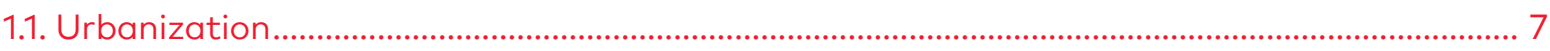

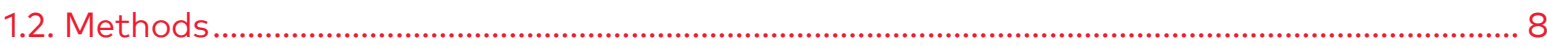

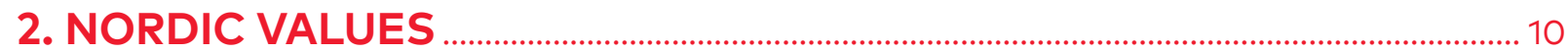

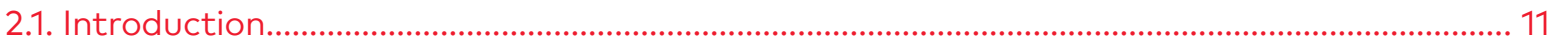

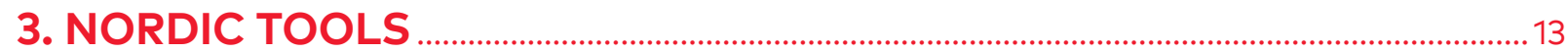

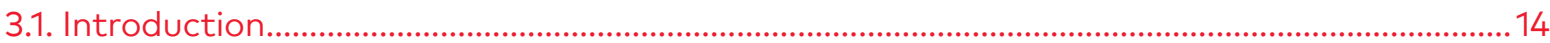

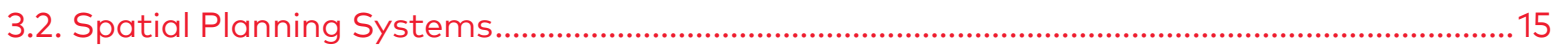

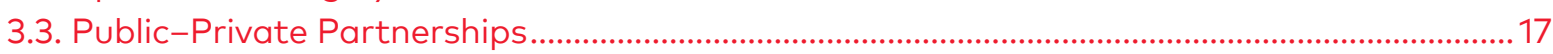

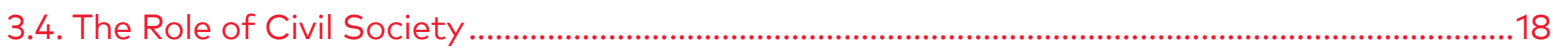

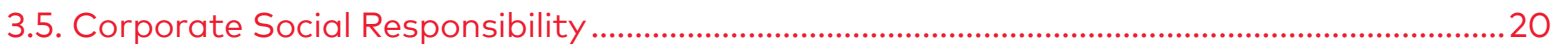

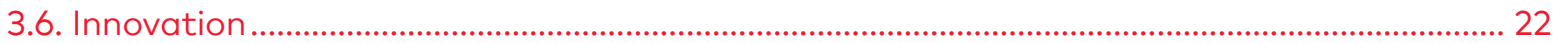

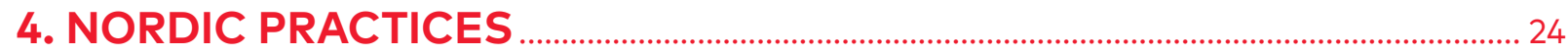

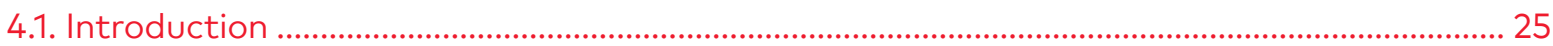

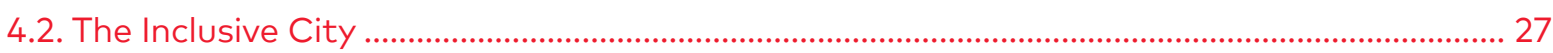

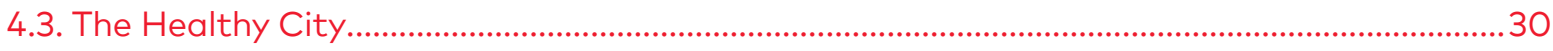

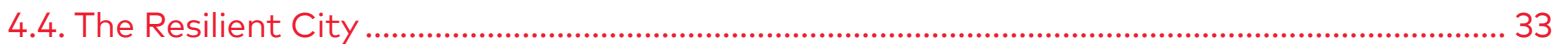

4.5. The Compact Green City .......................................................................................................... 36

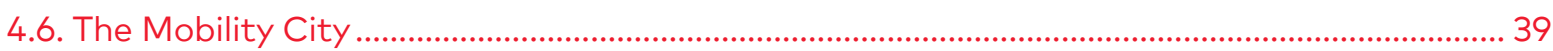

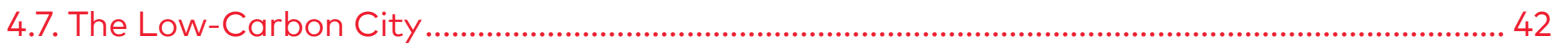

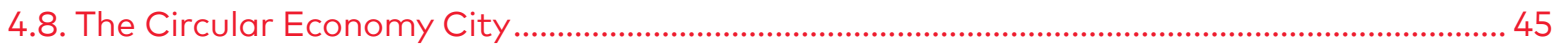

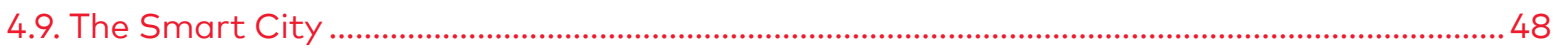

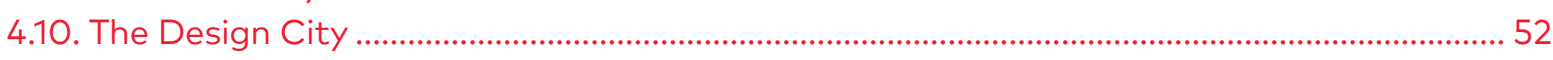

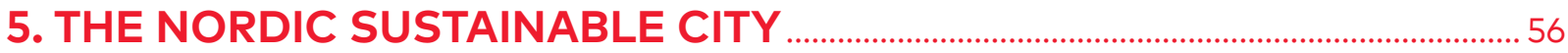

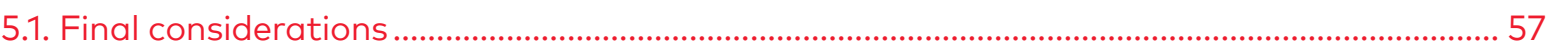

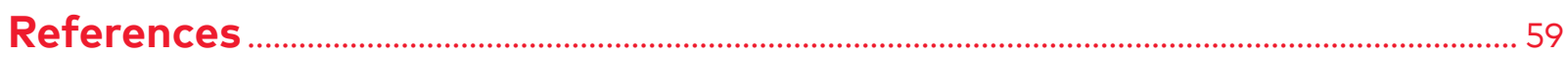

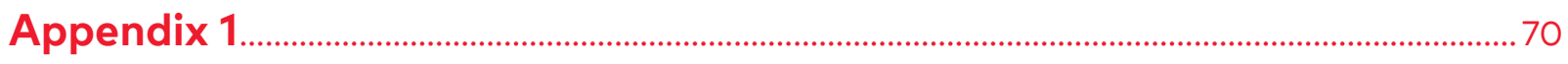

Appendix 2 2 


\section{List of figures}

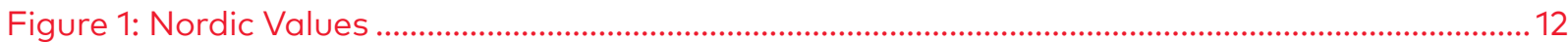

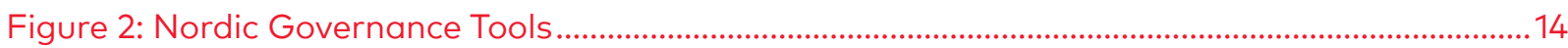

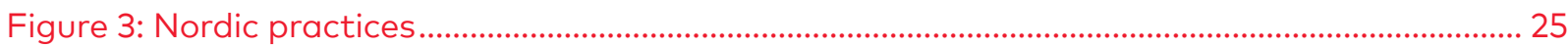

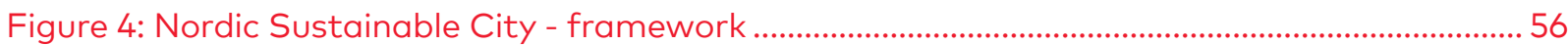

Figure 5: Telling the story to build cohesion among actors in the Nordic Region............................... 57

Figure 6: Telling the story to other audiences outside the Nordic Region .......................................... 57

\section{List of tables}

Table 1: Document analysis - cluster of main themes. 


\section{Introduction}

\subsection{Urbanization}

Worldwide cities have been growing at fast pace, half of the world population lives in cities and projections suggest that $66 \%$ of people will live in urban areas by 2050 (UN, DESA, 2015). Between 2014 and 2050, an additional population growth of 2.5 billion urban dwellers is expected, with approximately $90 \%$ of this development taking place in Asian and African cities (UN, DESA, 2015).

While cities have proven to be powerful drivers of economic growth they have also been source of several problems. Seventy-five per cent of the natural resources are consumed in cities which also account for $80 \%$ of global greenhouse emissions (UN 2011). In addition, crime, homelessness, youth unemployment, social unrest and social segregation are challenges that generally take place in urban environments.

These facts suggest that the fast urban growth has been accompanied by unsustainable patterns, that cannot be maintained in the future. Thereby, one of the biggest challenges, in a global perspective is to create sustainable environments for the rapidly expanding urban population. This, however, implies shifting our understanding about cities from merely consequence of growth to opportunities to respond and resolve environmental and social challenges.

Despite problems and challenges that the cities of the Nordic Region have, they have been performing well in many aspects related to urban sustainability. Copenhagen, for example, has established ambitious targets of becoming carbon neutral in a quite short term future (City of Copenhagen, 2009). Oslo will have a car-free city centre by 2019 as a strategy to slash greenhouse gas emissions. In addition, new technical building codes, product requirements, eco labelling of products, as well as innovative tax and incentive schemes have been created and implemented in the Nordic Region settling high standards for energy efficiency. These efforts to meet sustainability are pushing technological developments, increasing social awareness and leading to many alternative solutions to urban challenges.
Efforts towards sustainable urban futures are also mirrored in policies at different levels. Supporting a shared story about the Nordic Sustainable City, the Nordic Council of Ministers brings together the competences that the different countries and territories of the Nordic Region already have in regards to sustainable solutions to urban environments. Beyond creating a platform for communication, knowledge exchange, sharing norms and values and developing trust and commitment between different actors, this initiative may also generate synergies between different sectors persuading the development of new inventive sustainable urban solutions.

The strong tradition in co-operation in the Nordic Region also extends to other levels. Crosssectorial, triple-helix collaborations have been, for many years, a practice firmly established in Nordic countries. Creative solutions and the ability to link different actors involved in specific processes are characteristics that have enabled the Nordic Region to become a leader in innovation. Citybusiness in Finland is an example of a partnership in which six major cities had enabled companies to use public data and develop digital interfaces that advances competences in different fields (e.g. public participation, urban mobility, exchange of services). This initiative has created opportunities for companies to innovate, develop and test new products, while the public sector and communities also profit from solutions that facilitate everyday life and make cities more efficient.

The symbiosis between individual behaviour and consciousness about environmental problems is supported by urban policies and initiatives that enable sustainable solutions. In Copenhagen, for example, cycling is encouraged by bike paths that stretches for long distances in different directions and in Helsinki platforms for collaborative consumption ${ }^{2}$ and efficient mobility ${ }^{3}$ are becoming more popular.

2 https://www.sitra.fi/en/news/most-interesting-finnish-companies-circular-economy/

3 http://www2.liikennevirasto.fi/julkaisut/pdf8/Its_2015-56_maas_ services_web.pdf 
Thus, cities in the Nordic Region have been developing a set of initiatives, policies, tools, and instruments that have potential to offer solutions to sustainability challenges. Therefore, by telling a common urban story, communicating good practices and sharing experiences, cities in the Nordic Region might be contributing towards the UN Sustainable Development Goal number 11: 'Make cities inclusive, safe, resilient and sustainable'.

\subsection{Methods}

The methods employed to write the story include a literature review, semi-structured telephone interviews and focus group discussions.

The literature review has continued throughout the stages of this white paper. In October 2016, relevant documents in the field of urban sustainability at different policy levels and in various contexts (global, European and Nordic) were consulted. Some of these documents were the UN habitat III new urban agenda (UN, 2016), the United Nations sustainable development goals (UN, 2015), the Urban agenda for the EU-Pact of Amsterdam (EU, 2016), publications of the Nordic Working Group for Green Growth, Sustainable urban regions (NWG4) (Smas et al. 2016), The Nordic Eight (NCM, 2012), Nordic urban strengths and challenges (Norden, 2015), Faglig råd for bærekraftig byudvikling (Professional advice for sustainable urban development) (Kommunalog regionaldepartementet \& Miljøverndepartementet, 2013), the Nordic Built Charter (Norden, 2012), Nordic urban ways (Engström, 2016) and the Market analysis and action plan (Ramboll, 2016). The systematic review of these documents was useful for understanding the strengths and challenges of urban sustainability in the Nordic Region (see Table 1). These documents also outlined some aspects of the identity of cities in the Nordic Region. Between April and June 2017, 14 researchers from Nordregio specializing in a variety of fields such as mobility, bio-economy, innovation, planning, digitalization, circular economy, climate change adaptation, green infrastructure and architecture undertook an in-depth literature review to explore each of these aspects in relation to the cities in the Nordic Region.

Forty semi-structured interviews and two focus group discussions were conducted between November 2016 and March 2017. While the interviewees were identified through snowball sampling (e.g. Babbie, 2010), the focus groups were organized with the aim of covering groups that had been involved with issues of sustainability in cities of the Nordic Region. Academics, practitioners from local authorities, civil servants and company representatives working in the energy field, smart cities, transport, planning, architecture and design, climate change and waste sectors were interviewed and/or took part in the discussion (see Appendix 1).

The questionnaire template for the interviews set the scene by exploring tools, methods and processes that in the opinion of the interviewees could influence policies and practices regarding sustainable urban development in Nordic cities (Appendix 2). The interviews also provided access to additional material (e.g. websites, reports, presentations and examples of best practices) that facilitated further understanding of particular areas of expertise.

The responses of the interviewees were analysed to identify recurrent themes. This process included deconstructing the interview notes and transcriptions as well as the notes from the focus group discussions to obtain insights and developing an open coding system and linking these codes or units of data to form overarching themes and associated concepts.

Twenty-four experts took part in the two focus group discussions, co-organized by Nordregio and Nordic Innovation. Fifteen members from different fields (e.g. academics and private actors) participated in the discussion held in Copenhagen (4 November 2016), while nine professionals (e.g. planners, architects) affiliated with the Nordic City Network joined the discussion held in Malmö (21 December 2016).

The focus group discussions were important for the initial exploration of stories and for identifying possible themes and sectors in the Nordic story of sustainable urban development. They created a framework for dialogue, knowledge exchange and experiences from which a variety of perspectives on urban sustainability in the Nordic Region emerged.

Together with the analysis of major documents, the interviews and focus group discussions highlighted three features that were most relevant to the 'story' of Nordic sustainable cities:

Nordic values: the roots of sustainability,

- Nordic tools: enabling sustainability, and

- Nordic practices: urban sustainable outcomes. 
This framework-also called the core story of the Nordic Sustainable Cities-has been presented and discussed in workshops organized by Nordic Innovation held in various capital cities: Stockholm (16 March), Copenhagen (29 March), Oslo (4 April) and Helsinki (11 April). During these workshops, actors from private and public sectors provided input to shape the story of Nordic Sustainable Cities.

The development of this framework also profited from a discussion with the Nordic Built Cities Jury held in Malmö (29 April 2017) and a meeting with branding representatives from Sweden, Denmark, Finland and Norway in Oslo (10 May 2017). Both events were organized by Nordic Innovation. An additional workshop, organized by Nordregio to present the story to the Nordic City Networks (NCN), was held in Malmö (16 June 2017).

The discussions with a range of actors helped us to revise some of our initial assumptions, sharpening our arguments and improving the content of the story. 


\section{NORDIC VALUES Roots of sustainability}

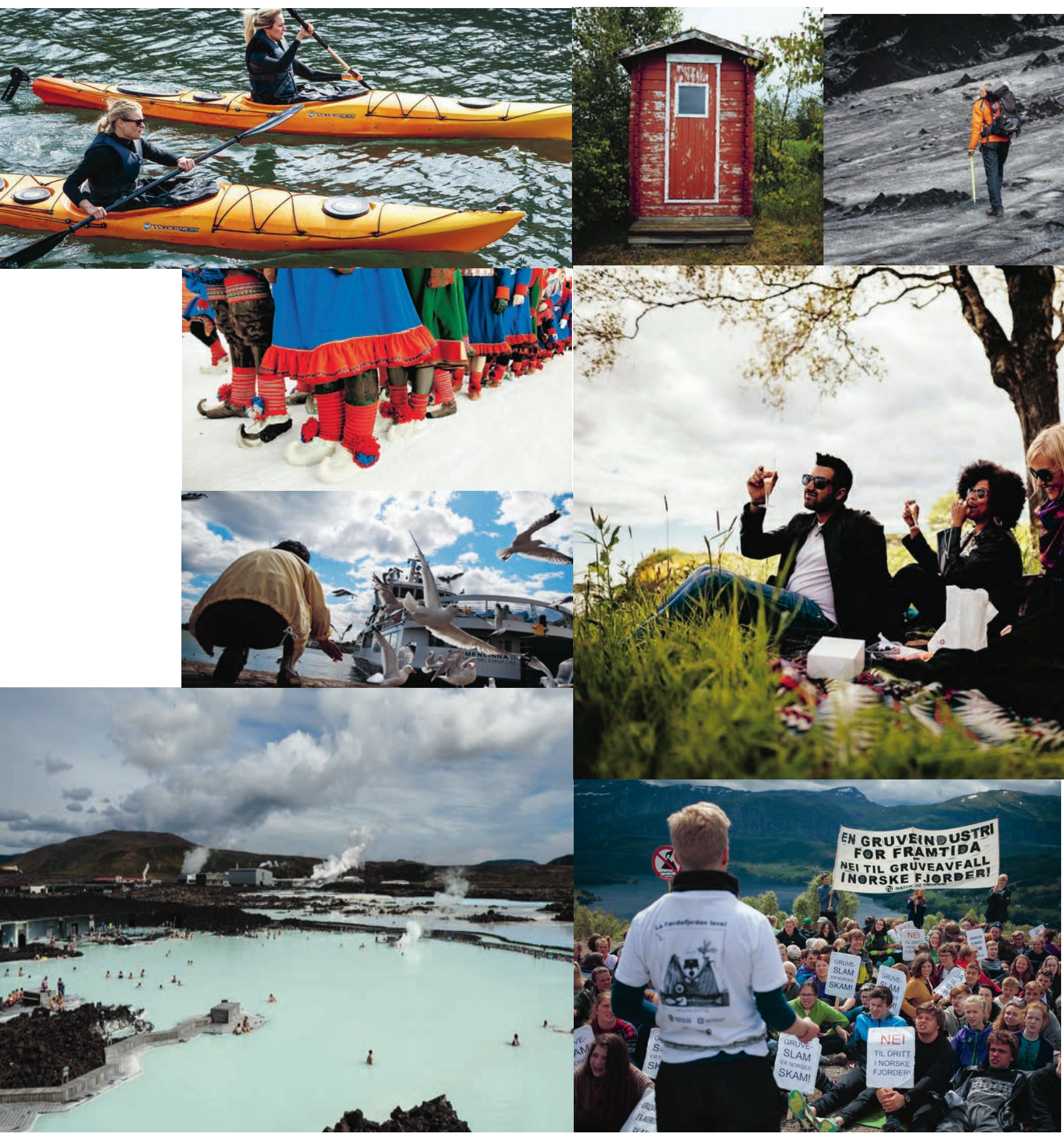


G6 am proud of being a member of Nordic democracy. The public realm is needed to create a democratic city, which is very important in planning.

MONICA VON SCHMALENSEE; CEO AT WHITE ARCHITECTS

\subsection{Introduction}

Working-class movements have had a great influence in shaping the values and qualities that underlie Nordic society (Alestalo et al., 2010; Rothstein and Stolle, 2003). In fact, the negotiation of tensions between labour and capital was the driving force in the establishment of the welfare state. The labour unions (1881) and farmers' movement (1918) in Sweden and the formation of independent workers' associations back in 1847 in Denmark are examples of the early organization of social movements.

Accordingly, the Nordic countries implemented social benefits quite early for the working class. For example, in the late 1890s, Denmark, Finland and Sweden already had insurance schemes to cover industrial accidents. Through a series of reforms in 1891, 1922 and 1933, Denmark implemented the National Pension System. Sweden adopted a similar system in 1913 (Alestalo et al., 2010). Beyond pushing the implementation of universal social security schemes, popular movements have strengthened collectivism, contributing to shaping a relatively non-hierarchical society. These movements are also regarded as a major school for democratic and organizational training and were crucial in mediating a smooth transition to democracy in the Nordic countries (Rothstein and Stolle, 2003).

These universal schemes, which extended social rights to the entire population rather than only to those in need, have also helped to prevent the exclusion of less affluent people while nurturing social solidarity among diverse people. They have placed group interests over individuals, while creating a shared recognition that all people are vulnerable to risks (Alestalo et al., 2009). Therefore, the principles of equality, universalism and democracy form the basis of the well-functioning Nordic society (Alestalo et al., 2009). They also explain why Nordic countries are frontrunners in supporting human rights, which even today are not upheld in some countries around the world.
The welfare state flourished after World War II, and for many decades social stability was supported by progressive income taxes and an egalitarian supply of public services which raised living standards in the Nordic countries (Kokko and Tingvall, 2007). Even today, despite globalization and internationalization, the welfare society still provides social insurance and many forms of social services (Lindbom, 2001). The longevity of the welfare state lies in the administrative structure, which is characterized by the autonomy of local governments and a robust central government. With a large public sector, this structure has strengthened local democracy and the participation of civil society in political affairs; it has been identified as one reason for the low levels of corruption in the Nordic countries (Lindbom, 2001).

The values shared by the Nordic countries have also been influenced by their long history of transnational regional co-operation. In 1907, parliamentarians from Sweden, Denmark and Norway already co-operated on issues related to social policy. In 1919, Copenhagen hosted the first of many regular joint meetings of senior political administrators. Nordic Social Statistics was established in 1946, and the free Nordic labour market in 1950. Collaborations on various issues paved the way for the establishment of the Nordic Council in 1952. Throughout these years, the Nordic Council promoted joint action, projects and research, raising the Nordic perspective in European and global debates, thus shaping and consolidating the identity of the Nordic Region.

For all these reasons, the Nordic Model is acknowledged in academic, political and mass media discourses. The positive connotations of this model are strengthened by Nordic countries' strong performance in global rankings regarding openness, trust, equality, environment and happiness. The State of the World's Mothers Report of 2015 (Save the Children, 2015) recognizes the Nordic countries as the best places in the world for women and children to live.

The fruit of historical processes, these values and qualities are thus part of the identity of the Nordic societies and are very important for the sustainability challenges that societies face today. With legitimacy at the individual level, values such as democracy, trust, transparency, openness and care for nature were highlighted by many of the interviewees as central to the story of the Nordic Sustainable Cities. 
Nevertheless, five values were selected as part of the Strategy of International Branding of the Nordic Region (NCM, 2015), which describes a common platform of shared Nordic strengths in the form of characteristics and values. Figure 1 illustrate the Nordic values.

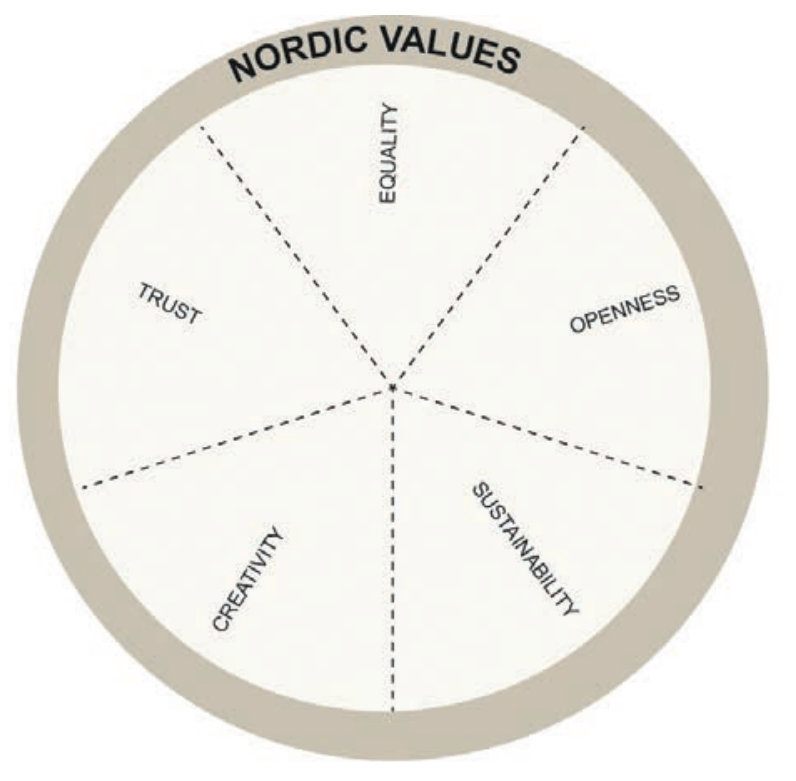

Figure 1: Nordic Values
Openness and a belief in everyone's right to express opinions

Trust in each other, and because of proximity to power, trust in leaders of society

- New ways of thinking, focusing on creativity and innovations

Sustainable management of the environment and development of natural resources

(NCM, 2015)

Thus, equality, openness, sustainability, creativity and trust are the values and qualities chosen to tell this story. These values have shaped the relationship between the state and the people and between the state and corporations, and they have influenced individual and collective behaviour. For this reason, they lie at the centre of this story. 


\section{NORDIC TOOLS Enabling sustainability}

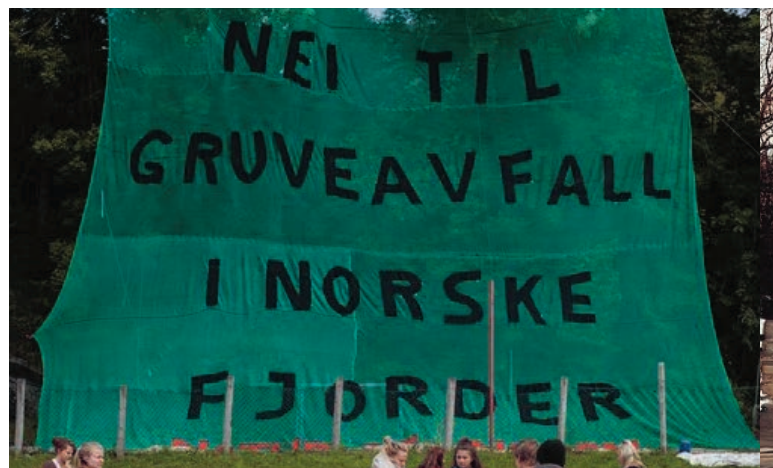

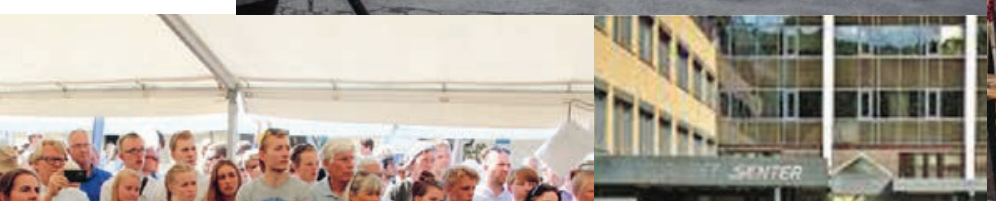
2.

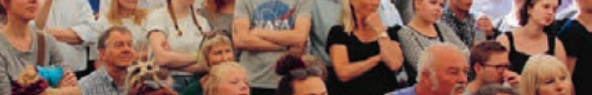
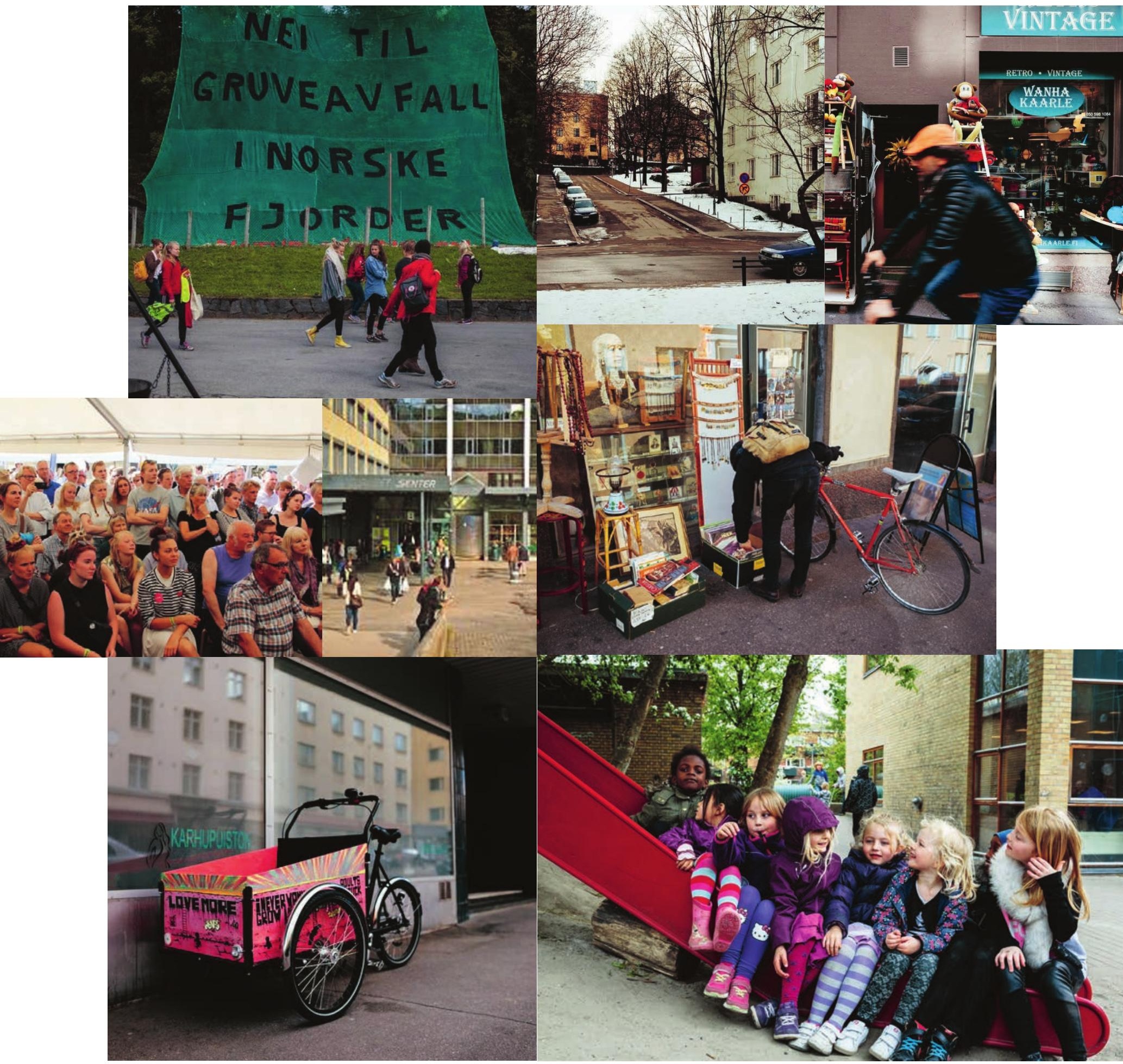
C6 The strong policy system and regulations give voice to different opinions not only to the private developers (...). The planning process includes communicating the proposals for development with the public through showings, meetings and discussions. However, it is quite a slow process since decisions must be discussed and regulated.

TONJE FRYDENLUND, MANAGING DIRECTOR AT SNØHETTA

\subsection{Introduction}

As discussed in the previous sections, the principles of democracy, equality and universalism have shaped the intimate relationship between people and government, and thus exert a strong influence on the overall institutional framework of the Nordic Region. In fact, institutions function both as constraints and as primary instruments of change of socio-economic behaviour. As such, they perform an important role in mediating transitions to sustainable futures.

Governing for sustainability implies bringing people and their differences together. It requires co-operation, negotiation and management of dissimilar interests to seek joint solutions that integrate economic, social and environmental aspects of an issue. In this respect, the inheritance of collaboration and collectivism also shapes good preconditions for the implementation of sustainable solutions.

The interviews and focus groups highlighted the importance of governance tools to mediate and enable the implementation of sustainable solutions. Based on these arguments, five governance tools or preconditions that establish a framework for action for actors in various contexts were deemed crucial in the implementation of sustainable solutions in the Nordic context. Figure 2 illustrate these tools.

Government, public and private actors, civil society and companies have networked in innovative ways, seeking alternatives to achieve sustainable outcomes in cities of the Nordic Region. Spatial planning is a governmental instrument that co-ordinates various aspects of socio-economic development across different sectors of society.

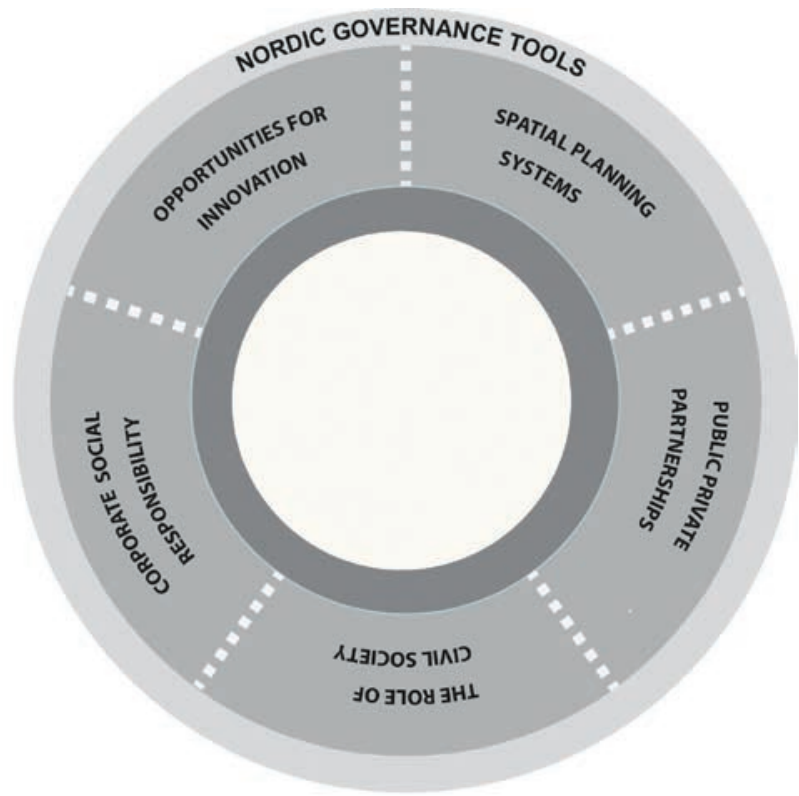

Figure 2: Nordic Governance Tools

Despite differences in the spatial planning systems of the Nordic countries, the strong power and autonomy of the local level is an important common factor in all of them. This has enabled a straightforward channel between people and government, for example, by facilitating the allocation of resources to areas or issues that are in line with the needs of local communities.

Public-private partnerships highlight the rise of neo-liberalism and new public management but represent a participative turn in policy and planning (Bogason, 2000; Bucchi and Neresini, 2008; Cass 2006). They offer an opportunity for the public sector to overcome budget deficits by sharing risks with the private sector while upholding public interests. Partnerships between public and private actors are complementary, and often deemed necessary for sustainable urban development.

Civil society acknowledges the role of people, non-governmental agencies and other associations that are active in the production and reproduction of urban environments. Perhaps inspired by the history of popular movements that made the Nordic countries social policy pioneers, bot-

\section{Inclusion of the private sector 14 - Creating public - private partnership with the inclusion of public participation.}

ANNA LOUISE HØJBJERG HENRICHSEN, PUBLIC AFFAIRS MANAGER AT DANFOSS 
tom-up initiatives remain present in public debate and policy-making. In addition, civil society can influence the decision-making process through participatory governance.

Socially responsible business models, partnerships and investments can also deliver sustainable solutions for cities by focusing on organizational governance, human rights, just labour and fair operating practices, the environment, sustainable consumer issues, and community involvement and development, including health, safety and gender issues. Companies are then the actors driving initiatives towards sustainability.

Innovation plays a significant role in enabling sustainable societal transition. Innovations are intended to create societal value and contribute to social, economic and ecological sustainability. Opportunities for innovation include open and inclusive relationships and collaborations with and between various actors, as they all have important roles in channelling resources in a sustainable direction to create change for a better future.

For many years, these initiatives have borne fruit in the Nordic context and have proven to be effective in delivering sustainable outcomes. The story of the Nordic cities is thus reinforced in a context characterized by innovative solutions, co-operation between levels, care for the environment and social responsibility. The importance of these tools for governing for sustainability is further developed in the following sections.

\subsection{Spatial Planning Systems Comprehensive, regulatory and with a strong local level}

Nordic planning systems have often been described as comprehensive and mature, with a systematic, hierarchical and rational approach to spatial planning (EC, 1997). In the Nordic countries, spatial planning is primarily done by local municipal authorities through comprehensive municipal plans and local development plans. National ministries and state authorities are mainly responsible for guiding spatial planning frameworks and directives and supervising issues of national interest, whereas the intermediate regional level often is marginal. Although there are many similarities, there are also differences both within and between countries, and systems are continuously being reformed and adapted to changes in society.

Local municipal authorities are the indisputable planning authority in the Nordic countries. In Sweden, it is often claimed that there is a local planning monopoly, which implies that the mu-

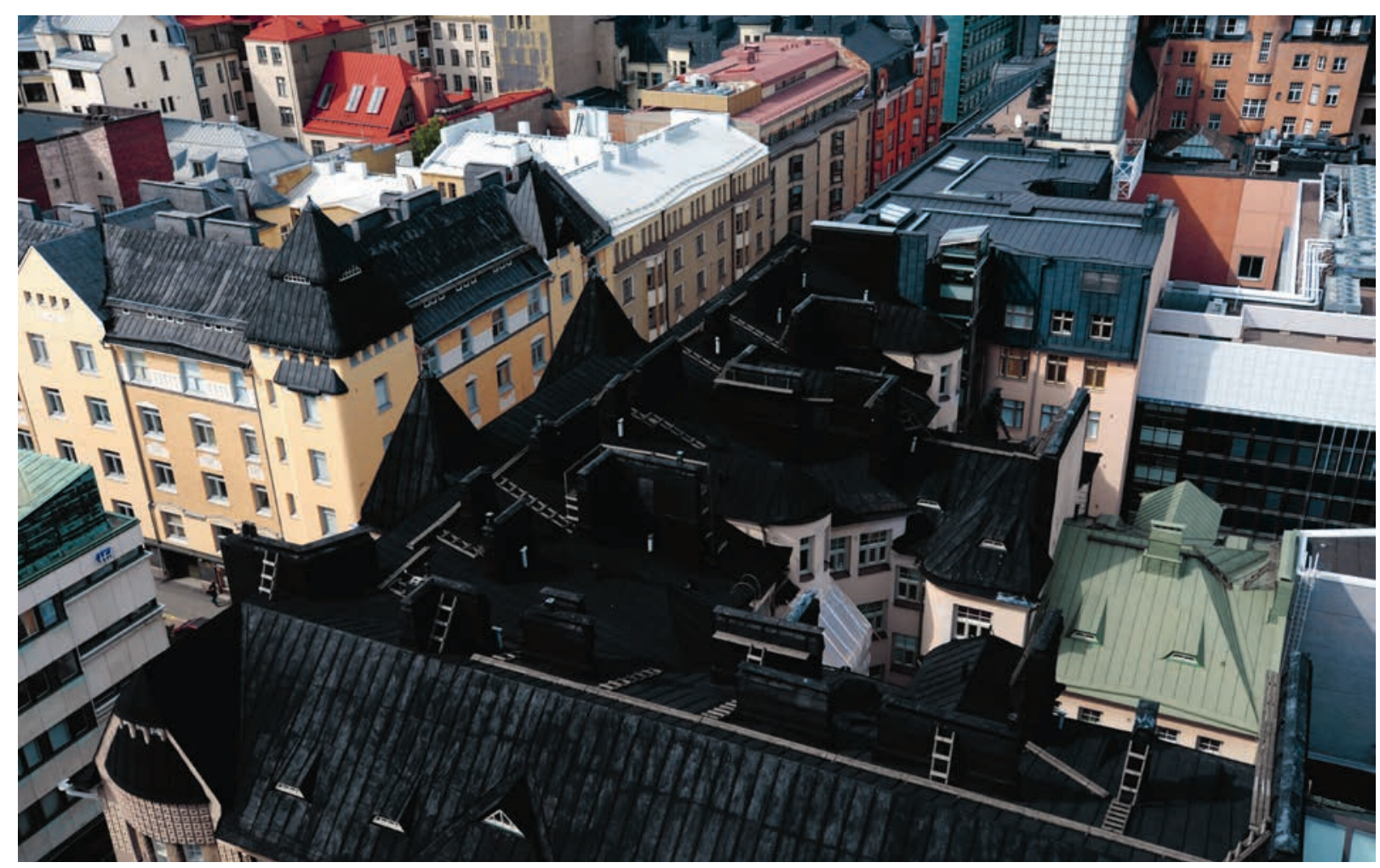

Roofs in Helsinki. Source: Johannes Jansson/norden.org 
C6 Nordic cities are well planned and well kept, due to in large part to the municipalities planning monopoly

MADELEINE NOBS, BUSINESS DEVELOPER AT NCC BUILDING \& CONSTRUCTION COMPANY

nicipality has the right to decide when and where development will take place. The most important local planning instruments (which exist in various forms in all Nordic countries) are comprehensive municipal and local development plans. In principal, all land in the Nordic countries is covered by a compulsory comprehensive municipal plan. These comprehensive plans that should steer land- use and the spatial development of the municipality are generally binding for the local development plans, except in Sweden, where the comprehensive plan is only a guiding instrument. A local development plan is generally needed for all urban development, even if a building permit (outside urban areas) can be granted based on the comprehensive plan.

Participation in the planning process at the local scale is rather extensive in the Nordic countries, and is regulated by national planning framework acts. For example, the generation of local development plans typically includes public exhibitions and hearings, as well as opportunities for stakeholders to appeal (Fredricsson and Smas, 2013). A plan is usually prepared by local planning departments (often in co-operation with private developers) and approved by a local political committee or council. In Norway, private developers can prepare a local development plan, which is then reviewed and approved by the local planning authorities. The often rather extensive public and bureaucratic process do however create tensions with needs for efficiency and new forms of market oriented management, between "input legitimacy and output efficiency" (Mäntysalo et al, 2011). In both Denmark and Norway, the comprehensive municipal plans, which because of their comprehensiveness are often rather time and resource consuming to produce, so they have been complemented with more flexible planning strategies.

Regional planning in the Nordic countries is a field of policy experiments and regional governance in the Nordic countries are becoming more divergent (Røiseland et al, 2015). Finland and Norway have statutory regional plans, but Denmark and Sweden only have regional plans for the capital regions. Iceland does not have a regional administrative level, but associations of municipalities can produce guiding regional plans. Greater Copenhagen is governed by the internationally known Finger Plan, which is a national directive that guides urban development along five transport corridors, with green wedges in between. Stockholm has a regional plan that is produced by the Stockholm County Council in accordance with the Planning and Building Act. The regional development plan for the Stockholm region specifies that regional development should focus on urban and regional cores. However, there are also many more informal spatial initiatives at the regional level across the Nordic countries that accompany more general regional policies and programmes.

How the national ministries and state authorities guide, intervene in and supervise local planning processes differs between the Nordic countries, depending partly on government systems and the traditional relationships between the national ministries and state authorities. However, there have been new developments in this area as well. For example, in Norway and Finland (and to some extent, in Sweden), new innovative forms of contractual arrangements between larger city regions and state authorities are emerging to coordinate land use, transport and housing. In the last few years in Sweden, Denmark and Norway, the responsibility for spatial planning issues has shifted toward ministries responsible for business and entrepreneurship rather than for environmental or social affairs. This is one indication of a general shift toward spatial planning facilitating growth and not being an obstacle to economic development.

The comprehensive regulatory, rational and hierarchical planning tradition is still strong in the Nordic countries. However, more flexible forms of strategic, market-oriented planning approaches have emerged as well as (and parallel to this) more communicative and participatory methods and in-

\section{The systematic approach to planning is especially important because it brings predictability.}

JUHA KOSTIAINEN, SENIOR VICE PRESIDENT, SUSTAINABLE URBAN DEVELOPMENT AT YIT CORPORATION 
itiatives to spatial planning. These different development paths have created interesting tensions within the dynamic field of Nordic spatial planning systems (Smas and Fredricsson, 2015).

\subsection{Public-Private Partnerships Co-operation between sectors and actors}

Public-private partnerships may be able to contribute to sustainable urban development, increase efficiency in urban planning and development processes and ease the financial burden on the public sector. Public-private partnerships are practised across the Nordic Region through various levels of institutionalized co-operation that range from loose co-operation via binding partnerships to joint organizations.

In urban planning and development, publicprivate partnerships typically refer to more or less formalized arrangements and forms of co-operation between public planning authorities and private developers. For example, there are many different models of public-private partnerships related to financing and the degree of risk aversion. In theory, public-private-partnerships can be divided into two types based upon whether the relationships between the public and private actors are vertical or horizontal. Vertical relationships refer to more traditional forms of co-operation, such as purchaser-provider models, whereas horizontal relationships involve less hierarchical networks between the public and private actors (Hanssen, 2012). In practice, public-private-partnerships often include characteristics of both vertical and horizontal relationships.

Globally, reaching the UN Sustainable Development Goals requires new innovative financing, especially for new infrastructure projects. To reach these global goals, public-private partnerships are seen as possible way to attract resources that can supplement limited government financing (Sharma, 2017). The Sustainable Development Goals Fund includes public-private partnerships as one of the three issues that cross-cuts all of its programmes, and it emphasizes the importance of joint efforts and shared responsibilities between governments and businesses to reach sustainable development.

Increasing co-operation between public and private actors in urban development is high on the agendas of Nordic countries. Internationally, there has been a great deal of focus on using publicprivate partnerships to finance large-scale infra-

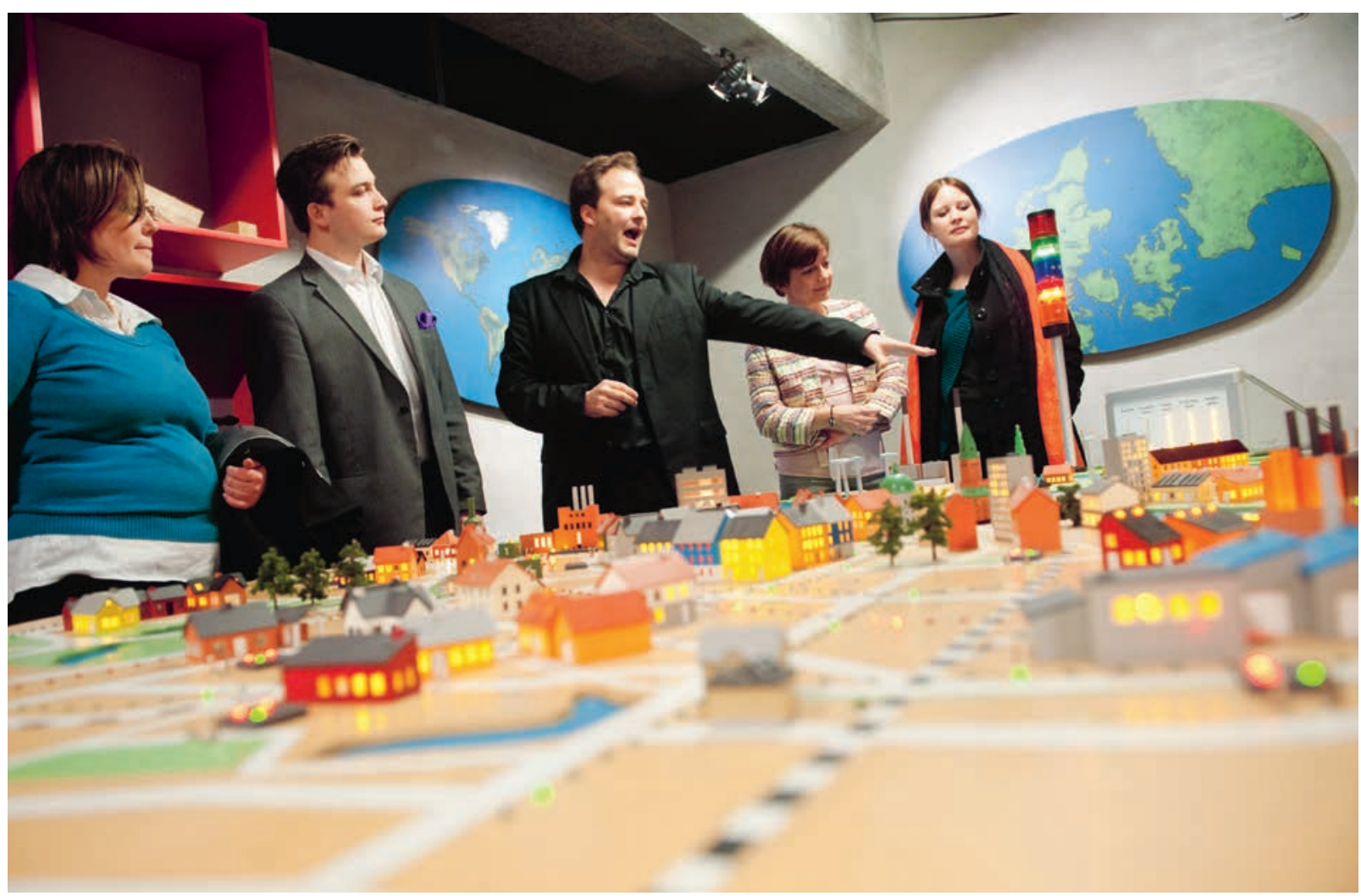

Energy and Water workshop. Source: Johannes Jansson/norden.org 
66 Planning that goes hand in hand with public-private partnerships is the way we do city planning. We bring private sector consultants, city staff and residents together at a very early stage in the design process. It is an ongoing dialogue, and you get a whole different output. A major part of the dialogue occurs in the conceptual phase. I think that has a considerable impact. There is massive involvement and you carry out numerous workshops months before the design phase starts. In that sense there is an imbedded democratic structure behind the Nordic model.

KLAUS LEHN CHRISTENSEN, DANISH CLEANTECH HUB - NYC

structure projects, but Nordic countries have also focused on public-private partnerships in urban development projects. Municipalities play a relatively strong role in Nordic urban planning. Many municipalities now see it as increasingly important to involve private developers early in planning processes, primarily to make these processes more efficient.

Policy exchanges and other types of co-operation between Nordic countries have been important for learning about different forms of publicprivate partnerships (e.g., Smas et al, 2015). For example, the concept of "partnership planning" is used in Finland to describe a variety of models in which municipal and private actors co-operate to prepare detailed plans and construction plans. The aim is to shorten the planning process and bridge the temporal gap between plan approval and the start of construction. In Denmark, partnership agreements in combination with so-called quality programs have been used as practical tools for public-private co-operation in urban development projects. In Norway, private developers are already allowed to propose local development plans, and this has had a significant impact on public-private relationships and led to other forms of governance, such as active land politics and joint development companies.
However, there are challenges in implementing public-private partnerships in the Nordic Region, where the ideals of citizen participation and openness are central. Partnerships between public authorities and private companies are often accompanied by the implication that secrecy and decreased transparency will limit the possibilities for public influence (Mäntysalo and Saglie, 2009). There is also a risk of public-private partnerships focusing on economic sustainability at the expense of environmental and social sustainability. Largescale urban development projects may focus on increasing land values and profits at the expense of liveability and sustainable living environments (Schmidt-Thomé, 2015).

The role of the public sector in setting up wellfunctioning institutional frameworks in Nordic countries is essential to ensure that public-private partnerships contribute to development that is economically, environmentally and socially sustainable. For example, in broad co-operation with public and private actors and local citizens and associations, the City of Malmö has developed and adopted a model for the regeneration of urban areas that ensures inclusive and efficient planning. Nordic and Baltic approaches to combining public-private-partnerships with citizen participation are also being developed in Norrköping, Turku, Riga and Tallinn (Perjo et al, 2016).

\subsection{The Role of Civil Society Side by side with the State}

Civil society has a relatively long history and established position in the Nordic countries-as an organizer of leisure activities and as a dialogue partner with the government in regard to social and political issues. There are also philanthropic organizations that help, educate or empower peo-

C6 We use dialogue effectively as a tool. We involve people early in the process as an inspiration for planning. We facilitate dialogue and discussion. We use digital tools, we invite people, we have a network in the neighbourhoods. We facilitate the bottom up process.

TINA SAABY, CHIEF CITY ARCHITECT OF COPENHAGEN MUNICIPALITY 


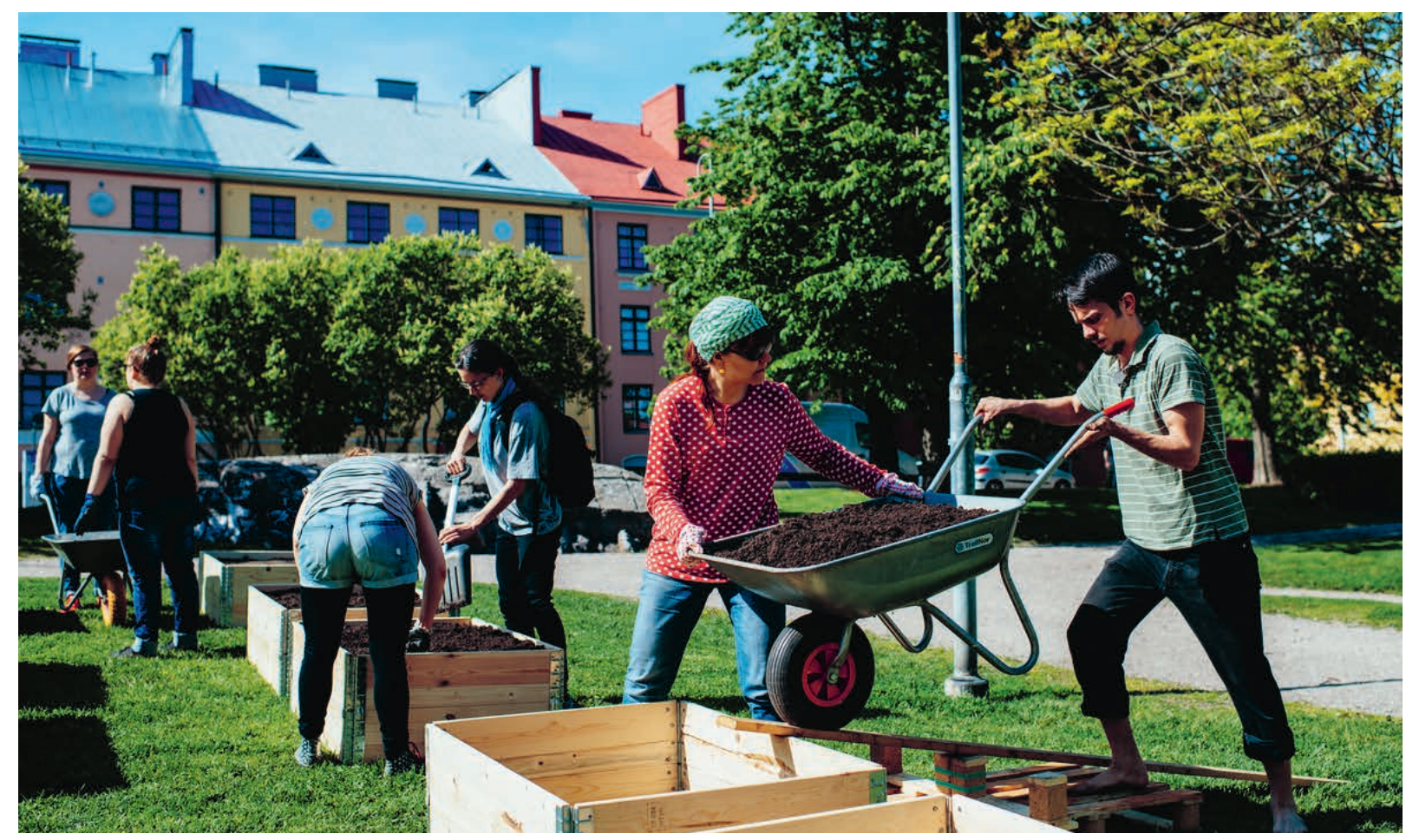

Planting in urban gardens in Helsinki. Source: Benjamin Suomela / Norden.org

ple in need. Civil society is an arena in which groups and organizations come together for a common purpose, idea or interest, for knowledge exchange, and for political, social and cultural activities. It has the potential to be an arena in which people of different socio-economic backgrounds meet as equals. On this arena, there are for example nonprofit and non-governmental organizations, foundations or trusts, religious organizations, social networks or other types of temporary collaborations or associations of people or groups. It is often dominated by voluntary and unpaid work, but that of course depends on the size of the organization and its funding. Organizations can receive public funding or fund their activities via donations and membership fees.

Civil society can become especially visible in extraordinary circumstances, such as when the flow of refugees to the Nordic countries increased dramatically in 2015; organizations and individuals came together to help with food, money, information, housing, etc., and new aid organizations were initiated. This is one example of how organizations in civil society can challenge or scrutinize the government. Also, associations require meetings, protocols, note taking and transparency-that is, the learning and practicing of local democracy. In academic terms, civil society is focused on building social capital and safeguarding local democ-

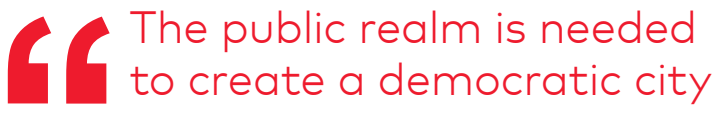
which is very important in planning.

MONICA VON SCHMALENSEE, CEO AT WHITE ARKITEKTER

racy, and it therefore carries promises related to sustainable development, particularly to the social aspects of sustainability. Civil society can also be an arena for trying out new solutions on a small scale that can later be scaled up and commercialized. It is possible to use study circles or small associations focused on a particular theme to apply for government funding, develop knowledge and ideas and give voice to certain interests or perspectives, such as local urban development.

In Sweden, the temperance movement, the worker's movement and the unions and the nonconformist churches are often seen as having been central to the development of voluntary and social engagement in the early 1900s. In Norway, collective and voluntary work is described as having emanated from premodern times and the tradition of collective work in and for the local village (Brochmann \& Rogstad, 2004: 329). Habermann and Ibsen described the Danish voluntary sector in the following way:

"The voluntary sector personifies personal freedom, social community and the fight for human 
rights, is the fertile soil for self-help, empowerment and integration, and functions as a school for democracy" (Habermann \& Ibsen, 2005: 6).

They also state that the Nordic welfare state has given rise to myths about the abilities of the State that have somewhat obscured the importance of the voluntary sector in the Nordic countries. In Denmark the voluntary sector is becoming increasingly professionalized. However, there are still traces of certain senses of morality, a certain organization of work and certain understandings of the individual and the collective. Today, the notion of civil society must be broadened from temperance, workers' rights and religion to include such issues as women's shelters, environmental education, sports and leisure activities, local urban development, urban gardening, neighbourhood events, cultural exchange and language training for immigrants.

Civil society organizations in the Nordic countries often are complementary to the responsibilities of the government or to commercialized services. That means that they can organize and campaign for interests, such as in the case of the temperance movement, religious organizations or amateur sports associations. It also means that they can mediate the relationship between the State and the citizens, such as in the case of trade unions or tenants' organizations. However, in most cases, it does not mean that they take over governmental tasks. Consequently, in the Nordic countries, civil society is central to the development of society, both in terms of values and with respect to certain practices. The Nordic network for civil society organizations (SOU, 2016) claims that being a strong civil society that influences decisionmaking is a Nordic characteristic.

Government funding of civil society organizations is not only a means of support for voluntary work, but also a means of control. This presents a potential challenge for $\mathrm{NGOs}$, in that they must at the same time be both dependent on and independent of the State. Another challenge is managing co-operation with the State in welfare services without being properly funded. With respect to the traditionally strong and highly trusted Nordic welfare state, giving responsibilities to and having confidence in civil society can be interpreted not only as empowerment, but also as the government trying to reduce its burden by placing it in the hands of voluntary and unpaid labour.

\subsection{Corporate Social Responsibility Nordic companies have global reach and responsibility}

Nordic cities are global cities. Thus, a genuine claim to the "sustainable city" title must transcend the physical boundaries of the city itself to consider the broader, often global implications of the activities that occur within it. Private actors play an important role in this work, both through their independent activities and by their increased presence in the public sphere through public-private partnerships. As such, the presence of socially responsible companies is an important precondition for the Nordic Sustainable City. The 'responsibility of enterprises for their impacts on society' is generally referred to as corporate social responsibility (CSR) (EC, 2011). As a concept, CSR first emerged in the U.S. around the middle of the twentieth century as a market-driven idea focused on aligning social responsibilities with profitability (Carson et al., 2011; Gjølberg, 2010). In practice, the simultaneous pursuit of social and economic goals in Nordic business has a much longer history. ${ }^{4}$ As outlined in the Nordic Strategy for Corporate Social Responsibility, the current Nordic vision for CSR is that the '[i]ntegration of social, environmental and ethical concerns into business operations and core strategy in dialogue with stakeholders will become mainstream practice' (NCM, 2012: 6).

Broadly speaking, two approaches to CSR are evident - implicit and explicit. Implicit CSR is typically associated with Europe and involves companies fulfilling their social responsibilities by operating within broadly accepted institutional frameworks (Carson et al., 2015). By contrast, explicit CSR is more commonly associated with North America and involves companies themselves identifying social goals and developing policies to pursue (Carson et al., 2015). Historically, Nordic companies have adopted an implicit approach to CSR (Strand et al., 2015), but more recently, scholars have noted a shift toward a more explicit approach (Carson et al., 2015; Gjølberg, 2010). Although there are challenges associated with taking a concept developed in one cultural context and applying it to another (see Gjølberg, 2010), there are also benefits. A more explicit approach allows Nordic businesses to be more expressive with respect to the way their corporate

4 For a comprehensive example, see Ihlen and von Weltzien Hoivikor's (2015) account of the history of CSR in the Norwegian context. 


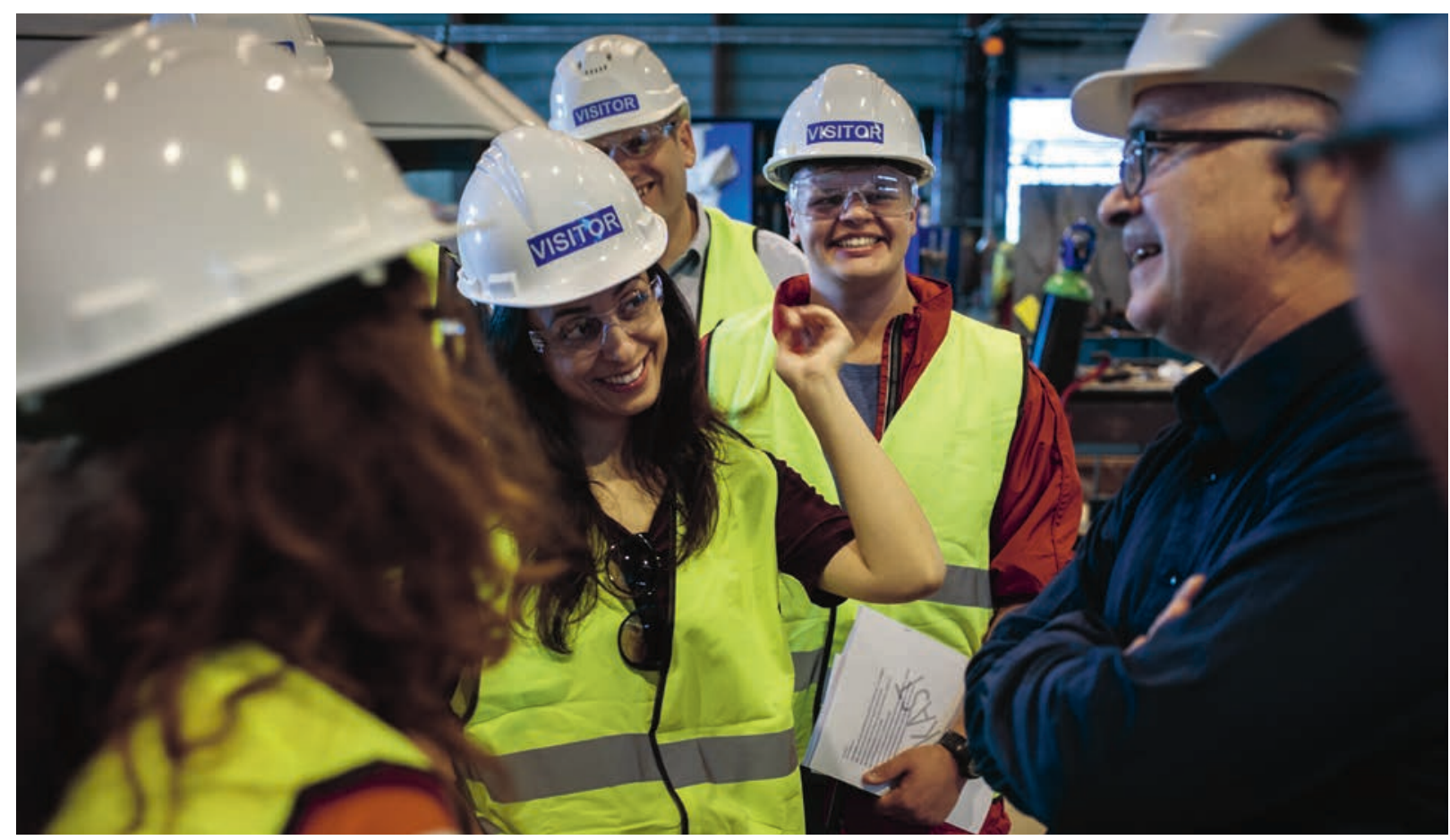

Hellenes Group, Hellenes house of Technology in Førde, Norway Source: Oddaleiv Apneseth/ Norden .org

\section{Traditionally there is a clear division of responsibility in} the energy sector'

ANNA LOUISE HØJBJERG HENRICHSEN, PUBLIC AFFAIRS MANAGER AT DANFOSS

values are shaped by sustainability goals (Carston et al., 2015), and provides scope for Nordic practice to act as a source of inspiration for other parts of the world (Strand et al., 2015).

Some scholars argue that through its adoption in the Nordic context, the concept of CSR has undergone something of a transformation (Gjølberg, 2010). The most notable element of this transformation is that a Nordic perspective positions CSR almost exclusively as a tool for global governance (see Gjølberg, 2010; NCM, 2012). Thus, understanding the role of CSR in enabling sustainability in Nordic cities means conceptualizing "the city" within its global context as described above. For example, both H\&M and IKEA have partnered with Save the Children and UNICEF to address challenges related to child labour (Strand \& Freeman, 2015). Similarly, Norsk Hydro is working with Amnesty International to train their managers and employees to deal with human rights issues in the various countries in which the company operates (Strand \& Freeman, 2015). Although these activities take place elsewhere, they contribute to the sustainability of the city by taking responsibility for the broader implications of the goods and services consumed within it.

Alongside its global governance role, there is a local dimension to CSR that has received considerably less attention in the Nordic Region. This disregard appears to be connected to the implicit roots of CSR described above. Historically, the strong role of the State in the Nordic countries, alongside a cultural context that promotes consensus and stakeholder collaboration, created a model of state-market-society relations in which CSR was (implicitly) implied (Carson et al., 2015; Strand \& Freeman, 2015). Although this legacy remains, the structures that underpin it have undergone substantial transformation in recent years, not the least of which is the increasing role of private companies in the provision of public sector services. The inclusion of social and environmental goals in public procurement processes has strong potential as a practical tool for promoting CSR in the context of this change locally, as well as abroad. Examples can be found in the recent work of the Nordic Council of Ministers on green public procurement (e.g., Baver et al., 2016), and in research by Swedwatch ${ }^{5}$ into labour conditions in global

5 Swedwatch (www.swedwatch.org) is an independent, not-for-profit organization that reports on Swedish business relations abroad, with a focus on social and environmental concerns. 
supply chains (Sjöström \& Scott Jakobsson, 2016). CSR can also be a useful tool to promote local production. By marketing themselves as socially and environmentally responsible, companies can justify the higher cost of locally produced goods to consumers (Carson et al., 2015).

\subsection{Innovation \\ Support for technological and sustainable innovation}

Innovation can be defined as a new combination of existing factors, including 'new things' as well as 'new ways' of combining things, and it can be specified as new goods (product innovation), new methods of production (process innovation), the exploitation of new markets, new sources of supply and new organizational models (Schumpeter, 1934; Fagerberg, 2005: 6). In other words, innovation is not a single event; it is a process of interactive knowledge exchanges between innovation system components such as public agencies, industrial partners and research institutions. In this framework, cities emerge as suitable seedbeds of innovation as they bring together different actors, knowledge bases and competences, thereby facilitating the generation and diffusion of innovation.
C.Clear environmental focus, high level of trust between businesses and the public sector, education and good governance.

Tolerance, putting all various

types of stakeholders together

to find the best solutions, distributive power, being able to make compromises and being open for innovations (...)

JONAS TÖRNBLOM, DIRECTOR MARKETING AND COMMUNICATION AT ENVAC GROUP AB

In Nordic countries, the process of knowledge creation is very concentrated. Cities play an integral part in innovation generation, contributing to the creation and diffusion of tacit knowledge, which is most effectively shared within a common geographical and social environment.

In the Nordic context, innovation has historically played an important role in providing novel solutions for sustainable urban development. The innovative nature of the Nordic Region can be largely attributed to a strong collaborative culture and interactive learning between actors and sec-

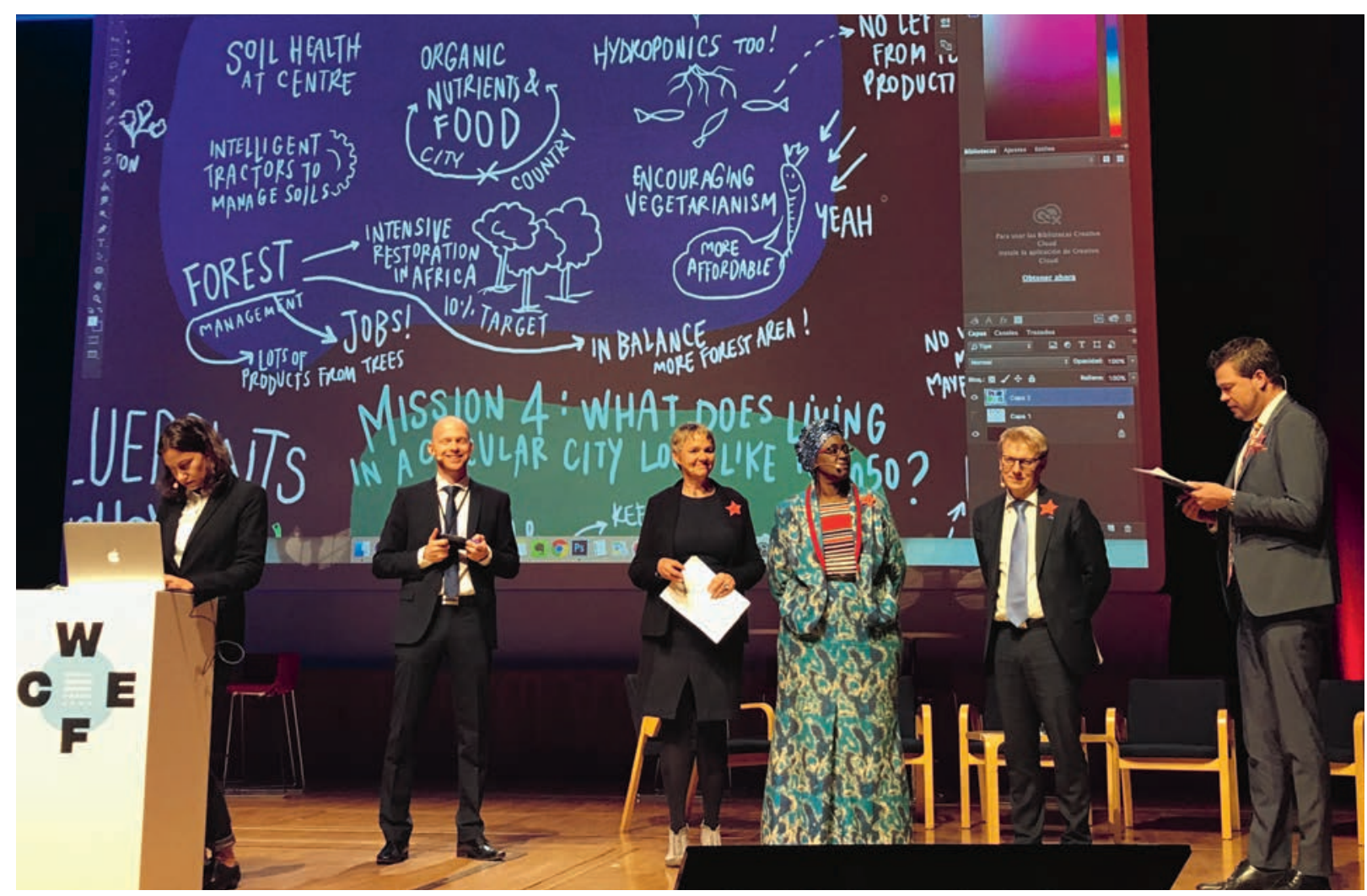

World Circular Economy Forum, Helsinki 2017. Source: Heidi Orava / norden.org 
tors that mediates the creation and implementation of technological and social innovation. This attitude stems from the belief that joint efforts have a more positive impact on society than do individual efforts. Consequently, public and private agents engage in co-operation for 'the mutual benefit of social development' (Fogelberg \& Thorpenberg, 2012). Promoting and strengthening co-operation between companies, universities and public actors - the so-called triple helix model (Etzkowitz \& Leydesdorff, 1997) - is widely practiced in all Nordic countries to create efficient innovation systems. Nordic governments take a particularly active role in technology and innovation policy by supporting the establishment of innovation centres and facilitating industry-university interactions (e.g., through different forms of public-private innovation partnerships).

In pursuit of innovative solutions to problems, Nordic countries have always relied heavily on technological innovation that emerges through a range of interactive processes for the development and diffusion of knowledge elements, which are essential for creating economic value (Edquist, 2002). Nordic countries are leaders in digitalization, including in the area of public services. The digitalization of society's various functions by means of modern technology significantly facilitates the transformation and upgrading of public services in Nordic cities. This approach to innovation reflects the Nordic welfare state model that has long favoured cross-sectoral collaboration to foster innovation and competitiveness and its long history of social movements (e.g., labour movements). The introduction of a social dimension in welfare services and organization has led to innovation activities in the Nordic countries that are primarily directed toward promoting social progress rather than technology per se. 


\section{NORDIC PRACTICES Sustainable outcomes}

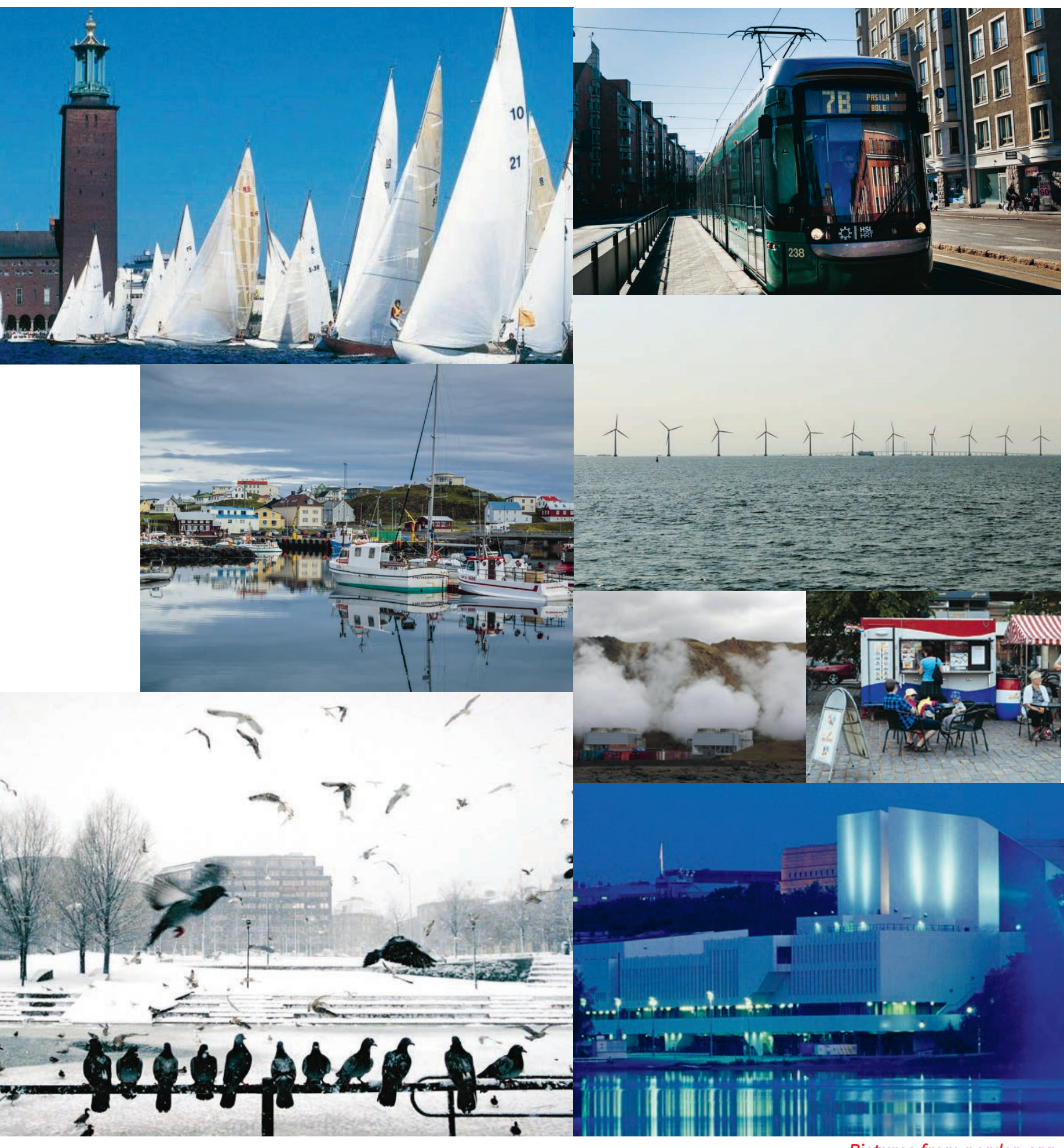




\subsection{Introduction}

This section describes and discusses Nordic practices. As shown above, Nordic values and tools are interrelated; these practices can be understood as a combination of both. For example, one can argue that values such as democracy have enhanced the participation of civil society in decision-making in the planning process, thus delivering inclusive practices in cities of the Nordic Region.

The choice of these practices followed a nonlinear process that encompassed the interplay between a literature review, research on good examples and Nordic distinctiveness. Six documents that were influential in the debates on urban sustainability at the global, European and Nordic levels were initially consulted. Based on the main issues identified in these documents, a cluster analysis was performed to identify associations and patterns among the documents (Macia, 2015). Table 1 illustrates part of this process. The different colours indicate the recurrence of themes in the different documents.

\begin{tabular}{|c|c|c|c|c|c|c|}
\hline $\begin{array}{l}\text { UN Habitat III } \\
\text { New Urban } \\
\text { Agenda } \\
(\text { UN,2016) }\end{array}$ & $\begin{array}{l}\text { EU Urban } \\
\text { Agenda } \\
(E \cup, 2016)\end{array}$ & $\begin{array}{l}\text { Nordic Built } \\
\text { Chart } \\
\text { (Norden, 2012) }\end{array}$ & $\begin{array}{l}\text { The Nordic } \\
\text { Eight } \\
(\mathrm{NCM}, 2012)\end{array}$ & $\begin{array}{l}\text { Professional } \\
\text { advice for SUD } \\
\text { (Kommunal - } \\
\text { og regional \& } \\
\text { Miljøvern- } \\
\text { departementet, } \\
\text { 2013) }\end{array}$ & $\begin{array}{l}\text { Market analysis } \\
\text { \& action plan } \\
\text { (Rambøll, 2016) }\end{array}$ & $\begin{array}{l}\text { NORDIC } \\
\text { PRACTICES }\end{array}$ \\
\hline $\begin{array}{l}\text { Social } \\
\text { function }\end{array}$ & $\begin{array}{l}\text { Inclusion of } \\
\text { migrants and } \\
\text { refugees }\end{array}$ & $\begin{array}{l}\text { Made for } \\
\text { people }\end{array}$ & $\begin{array}{l}\text { Growing } \\
\text { compactly and } \\
\text { efficiently }\end{array}$ & $\begin{array}{l}\text { Compact } \\
\text { growth }\end{array}$ & $\begin{array}{l}\text { Architecture } \\
\text { and design }\end{array}$ & $\begin{array}{l}\text { The inclusive } \\
\text { city }\end{array}$ \\
\hline Participatory & Air quality & $\begin{array}{l}\text { Innovative } \\
\text { performance }\end{array}$ & Transport & Protect nature & $\begin{array}{l}\text { Climate } \\
\text { adaptation }\end{array}$ & $\begin{array}{l}\text { The healthy } \\
\text { city }\end{array}$ \\
\hline $\begin{array}{l}\text { Gender } \\
\text { equality }\end{array}$ & Urban poverty & $\begin{array}{l}\text { Qualities of } \\
\text { nature }\end{array}$ & $\begin{array}{l}\text { Street lighting: } \\
\text { intelligent } \\
\text { technologies }\end{array}$ & $\begin{array}{l}\text { Sustainable } \\
\text { transport } \\
\text { solutions }\end{array}$ & $\begin{array}{l}\text { Conceptual } \\
\text { planning and } \\
\text { development }\end{array}$ & $\begin{array}{l}\text { The resilient } \\
\text { city }\end{array}$ \\
\hline $\begin{array}{l}\text { Economic } \\
\text { growth }\end{array}$ & Housing & Zero emissions & $\begin{array}{l}\text { Energy: moving } \\
\text { from fossil } \\
\text { fuels }\end{array}$ & Walkability & $\begin{array}{l}\text { Energy } \\
\text { solutions }\end{array}$ & $\begin{array}{l}\text { The } \\
\text { compact } \\
\text { green city }\end{array}$ \\
\hline $\begin{array}{l}\text { Territorial } \\
\text { functions }\end{array}$ & $\begin{array}{l}\text { Circular } \\
\text { economy }\end{array}$ & $\begin{array}{l}\text { Nordic design } \\
\text { tradition }\end{array}$ & $\begin{array}{l}\text { Water } \\
\text { protection }\end{array}$ & $\begin{array}{l}\text { Active and } \\
\text { attractive } \\
\text { public open } \\
\text { spaces }\end{array}$ & Governance & $\begin{array}{l}\text { The mobility } \\
\text { city }\end{array}$ \\
\hline $\begin{array}{l}\text { Urban } \\
\text { mobility }\end{array}$ & $\begin{array}{l}\text { Jobs and skills } \\
\text { in the local } \\
\text { economy }\end{array}$ & Built to last & $\begin{array}{l}\text { Smart } \\
\text { information } \\
\text { management }\end{array}$ & $\begin{array}{l}\text { Support } \\
\text { business and } \\
\text { culture }\end{array}$ & ICT solutions & $\begin{array}{l}\text { The low } \\
\text { carbon city }\end{array}$ \\
\hline $\begin{array}{l}\text { Disaster risk } \\
\text { reduction }\end{array}$ & $\begin{array}{l}\text { Climate } \\
\text { adaptation }\end{array}$ & $\begin{array}{l}\text { Utilises local } \\
\text { resources }\end{array}$ & $\begin{array}{l}\text { Behaviour: } \\
\text { Changing } \\
\text { attitudes }\end{array}$ & $\begin{array}{l}\text { Urban planning } \\
\text { for climate, } \\
\text { health and } \\
\text { environment }\end{array}$ & $\begin{array}{l}\text { Planning and } \\
\text { construction } \\
\text { services }\end{array}$ & $\begin{array}{l}\text { The circular } \\
\text { economy } \\
\text { city }\end{array}$ \\
\hline \multirow[t]{5}{*}{$\begin{array}{l}\text { Protect } \\
\text { ecosystems }\end{array}$} & $\begin{array}{l}\text { Energy } \\
\text { transition }\end{array}$ & $\begin{array}{l}\text { Collaboration } \\
\text { across borders } \\
\text { and disciplines }\end{array}$ & & $\begin{array}{l}\text { The role of } \\
\text { the national } \\
\text { authorities }\end{array}$ & $\begin{array}{l}\text { Redevelop- } \\
\text { ment projects }\end{array}$ & $\begin{array}{l}\text { The digital } \\
\text { city }\end{array}$ \\
\hline & $\begin{array}{l}\text { Sustainable use } \\
\text { of land }\end{array}$ & $\begin{array}{l}\text { Scalable } \\
\text { concepts }\end{array}$ & & Housing & Transports & $\begin{array}{l}\text { The design } \\
\text { city }\end{array}$ \\
\hline & Urban mobility & Profitable & & $\begin{array}{l}\text { Sustainable } \\
\text { building } \\
\text { techniques }\end{array}$ & $\begin{array}{l}\text { Water and } \\
\text { Sanitation }\end{array}$ & \\
\hline & $\begin{array}{l}\text { Digital } \\
\text { transition }\end{array}$ & & & $\begin{array}{l}\text { Support urban } \\
\text { research }\end{array}$ & & \\
\hline & $\begin{array}{l}\text { Public } \\
\text { procurement }\end{array}$ & & & & & \\
\hline
\end{tabular}


G6 The free, relaxed and informal tone between authorities, housing companies, and developers - it's all about dialogue.

PEDER BALTZER, CHIEF CITY ARCHITECT, MUNICIPALITY OF AALBORG.

Energy issues (efficiency and transition to biosources), green structures, water and air quality, and Nordic design were some of the issues that emerged from this analysis. The Nordic Charter (Norden, 2012) and Sustainable Development Action-The Nordic Way (NCM, 2017) also influenced the selection of practices. While the 10 principles highlighted in the Charter provided goals for interventions in urban environments, the Sustainable Development Action explained the relationship between the five goals and 16 objectives outlined in the Nordic Strategy for Sustainable Development (NCM, 2015) with the SDG goals. Further emphasis on both documents is expected to highlight the Nordic perspective.

This process indicated nine practices/outcomes: inclusive, healthy, resilient, compact green, mobility, circular economy, low carbon, smart and design. These labels (e.g. inclusive, healthy, smart) have often been applied in the literature on urban sustainability. For example, a 'smart city' is defined as 'a city performing well in a forwardlooking way in economy, people, governance, mobility, environment, and living, built on the smart combination of endowments and activities of selfdecisive, independent and aware citizens' (Giffinger et al., 2007). Nevertheless, the main idea of these labels was to highlight the key qualities and characteristics of cities in the Nordic Region in relation to these themes. Therefore, the question: 'In what ways can the inclusive city (or healthy, resilient, compact-green, etc.) be characterized in the Nordic context?' guided the literature review and

\section{6 The human scale - based on a long history of fellowship and on the Nordic welfare model - accommodates all.}

HOLGER BISGAARD, SENIOR ADVISOR AT THE DANISH BUSINESS AUTHORITY research of good initiatives/projects implemented in the cities of the Nordic Region. This question highlights the Nordic distinctiveness in various areas that intersect in the sustainability of urban environments, but the challenges that cities from the Nordic Region face are not overlooked.

A particular quality and/or characteristic was judged valid if it could be found in cities of at least three Nordic countries. In this respect, the argument that 'the natural environment underlines the urban development of Nordic cities' was based on the preservation of green edges and the protection of aquatic ecosystems seen in the urban form of Stockholm, Helsinki and Copenhagen. The consistency between the literature review and good examples also revealed the main competences of the Nordic Region in implementing sustainable urban solutions. The outcome of the interviews and focus group discussions also influenced the choice of these practices. Figure 5 illustrates the practices.

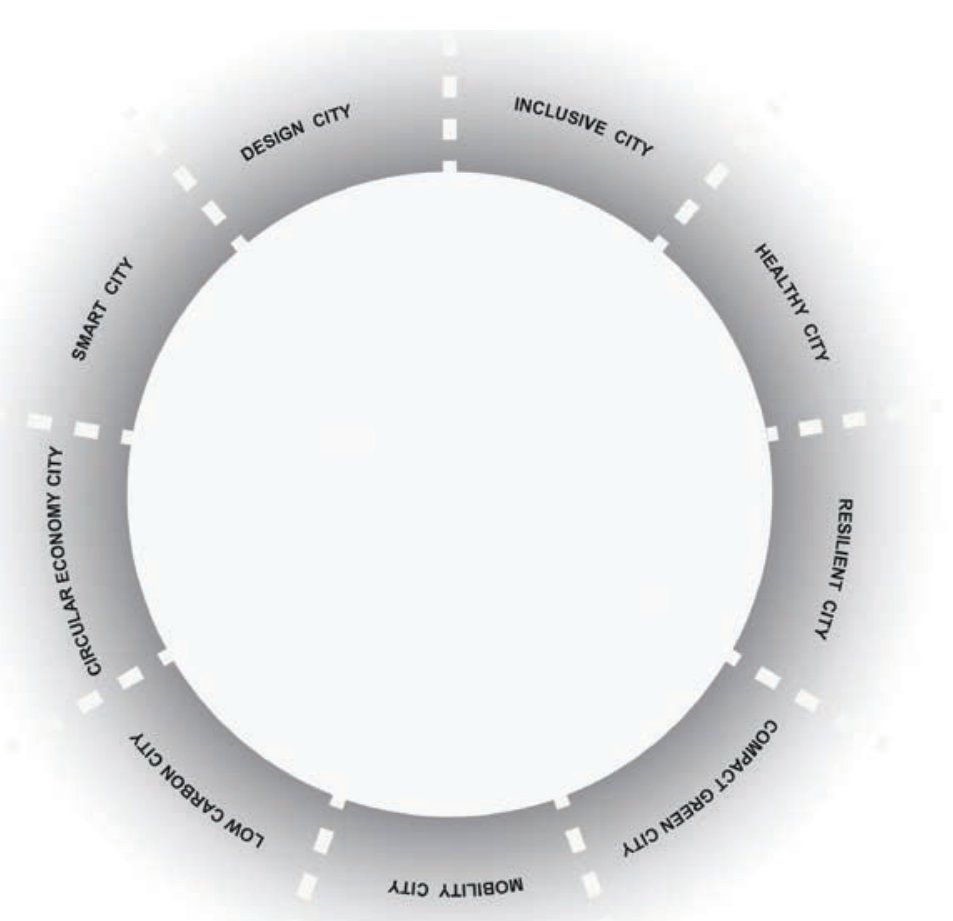

Figure 3: Nordic practices. 


\subsection{The Inclusive City Developing the city with a social awareness}

Social inclusion and ambitions for a just city are central to urban sustainability in the sense of social equality between citizens, equal opportunities to live and work in the city and the reduction of social conflicts. In the Nordic context, three aspects of an inclusive city will be highlighted in the following section - inclusive public spaces, participatory planning and housing policy.

\section{Inclusive public spaces}

Public spaces in Nordic cities are relatively well designed and open, both in terms of physical accessibility and low "entrance fees" in economic and social or cultural sense. It is possible to claim that the "right to the city" for all citizens has long been an urban planning ambition. First, in post-war urban planning, there was a strong desire to create a built environment that encouraged a democratic society as well as a democratic citizenry. This took the form of small-scale neighbourhoods with generous open green spaces, and small local centres with commercial, public and cultural amenities, all of which were intended to encourage social interaction, education and democratic values. Today, these spaces are still important for political functions, social events and commercial and public services. Second, with his focus on the "spaces between the buildings", the influence of Danish architect Jan Gehl on Nordic cities can be seen in the region's emphasis on human scale and peopleoriented urban design.

In recent decades, Nordic cities have been quite ambitious regarding accessibility and safety in public spaces. Strategies for accommodating people with physical or cognitive disabilities have been developed in both urban planning and design. There is a Nordic charter for universal design (Björk, 2014), and the planning processes in the Nordic countries has checkpoints to ensure that the interests of these populations are considered in the design of physical environments and their amenities. Children and parents, the elderly and others who need assistance with public transport and other means of travel in the city are also considered; everyone should be able to cross the street, rest in the park or orient themselves safely in the city.

Nordic cities also use urban design and planning to create a social mix. By combining functions and types of commercial and public services, city
C6 There is a willingness to invest in "feel good environments". People have the same willingness and contribute making good urban environments to hang out with families and friends.

SVERRIR BOLLASON, PLANNING CONSULTANT AT VSO

centres often attract a relatively mixed crowd, including people who are shopping, seeking entertainment or participating in cultural events. In addition, although the privatization of public spaces does happen in Nordic cities, such as with closed shopping centres, there is still a strong emphasis on the necessity of open squares, parks and open and accessible urban waterfronts.

\section{An inclusive planning process}

Participatory planning practices are believed to contribute to more democratic societies. Proponents argue that citizen participation increases the transparency of planning processes and makes it possible for experts to include a diversity of users' knowledge and experiences. Furthermore, it builds social capital and can lead to greater participation by groups that would otherwise have weak political influence in society (e.g., Kugelberg \& Trovalla, 2015: 16-17; Lindholm et al., 2015).

Common challenges associated with participatory planning processes include the risk that the positions of participants with an already strong political voice will be strengthened, as well as the potential for disappointment if citizens feel that their views were not considered in the way that they had envisioned. Another issue is related to the political system of representative democracies: what role do "parallel" participatory processes play in the formal political decision-making process?

In Nordic countries, planning and building legislation provides opportunities for the public to express their views on ongoing plans. Public debates in the 1960s included critiques of rational planning as dominated by experts. Critics pointed to the need to include the everyday life experiences of citizens in urban development (Listerborn, 2015). In the 1980s and 1990s, public hearings were included in the planning process by law. In the last few decades, there have been many experiments at the local level to develop methods to include 


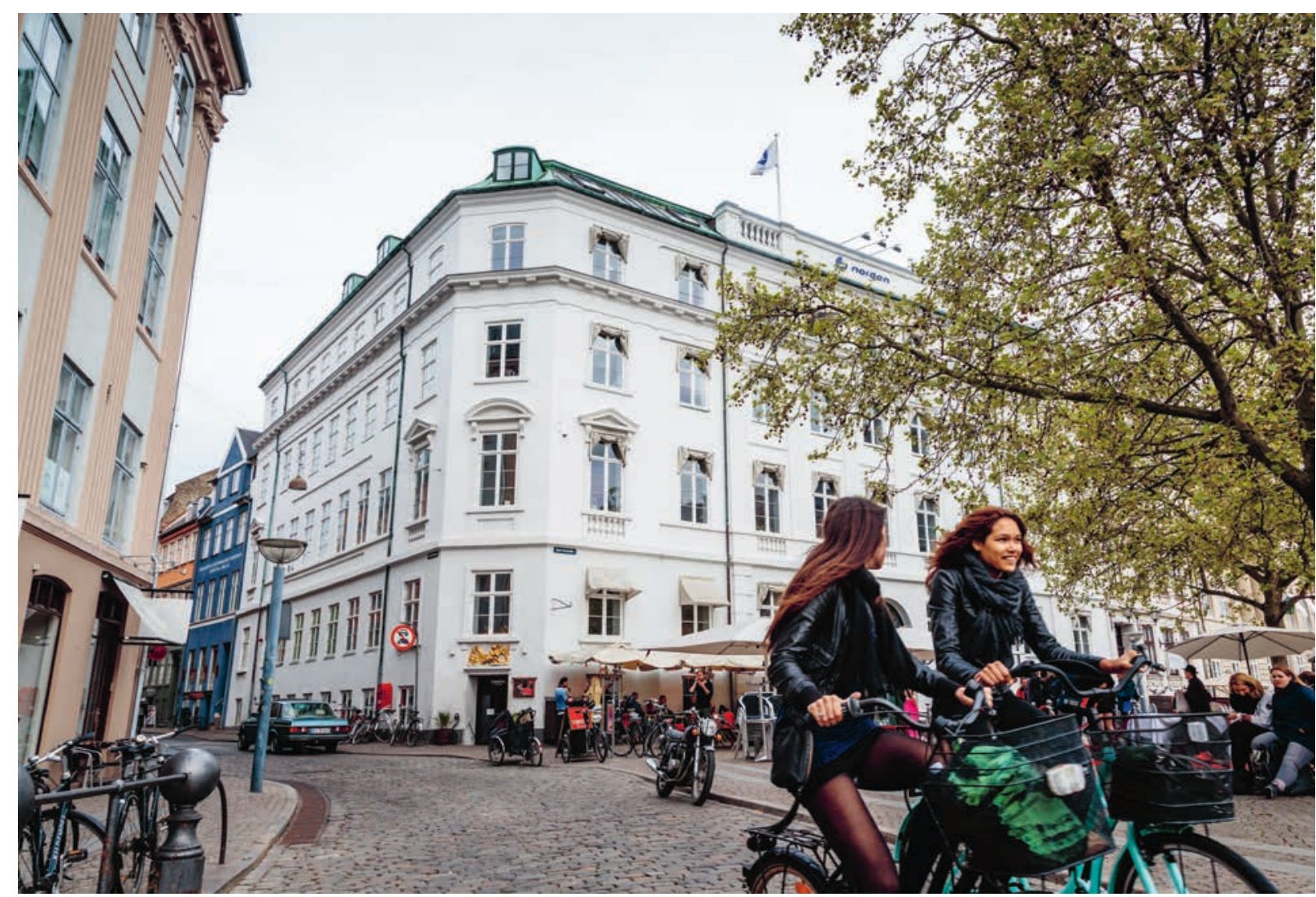

Ved stranden 18, Copenhagen. Source: Yadid Levy, Norden.org

the public in planning processes (e.g., Kugelberg \& Trovalla, 2015; Lindholm et al., 2015). In Sweden, this has sparked debates about how to safeguard citizen input while maintaining efficient planning processes that can address the massive new development needs owing to a housing shortage.To overcome the challenges of representative participation, many local administrations try various ways to target more marginalized populations. The Swedish Association of Local Authorities and Regions provide national networks for knowledge exchange and methods like participatory budgeting or digital tools to encourage new groups to be involved are some examples of ongoing activities.

\section{Inclusion via housing policy}

Segregation and gentrification are global urban challenges, and housing policy can contribute to making cities and neighbourhoods inclusive and open to all by such means as affordable housing and social mixing policies. It should also be emphasized that the Nordic countries have a very high standard of housing across housing types, even in comparison with other EU countries. Although there have been changes in the last few decades, the Nordic countries are still characterized by the idea of housing as a right. This is addressed either through public housing or through needs-tested social housing. However, there are differences between the Nordic countries. In Sweden and Denmark, housing was a key part of the welfare state project, and Sweden in particular had strong focuses on housing as a social good and on equal housing opportunities for all (Andersen, 2012). In recent years, Finland has worked at the ministerial and city levels to prevent homelessness by adapting the "housing first" principle, in which the right to housing is prioritized as the proper basis for targeting the social problems faced by homeless persons. This is based on broad co-operation and agreements between the ministerial level and the biggest cities, among other things. In recent years, Finland has been the only European country with decreasing homelessness, although Denmark also has quite successful programs targeting homelessness.

Segregation is still a major challenge in many Nordic cities, but cities are introducing innovative approaches to tackle the problems. Different types of social mix policies, such as ensuring the availability of different tenure forms in all neighbourhoods, help to prevent segregation at the 
neighbourhood level. Helsinki is known for its social mix policy, which was established in the 1970 s, and regulates the shares of different tenure forms at the neighbourhood level to ensure a mix of populations in each area and prevent spatial segregation. The city of Gothenburg in Sweden is currently experimenting with new ways of steering rents in newly-built apartments in the large Frihamnen brownfield development project.

\section{International outlook}

Inclusive cities and social aspects of urban sustainability may well be higher on the agenda than ever before, especially with respect to policy. Even Richard Florida, the world famous American urban economist who has been preaching about competitiveness to cities all over the world, as well as about attracting the "creative class" through urban development, is reconsidering. Instead, his current message focuses on the importance of inclusion and the problem of gentrification (Florida, 2017).

Considering that the term "inclusive cities" can be interpreted in a variety of ways, there is ample research in this area. For example, inclusiveness can be about segregation, discrimination and living in "divided cities" (e.g. Gaffikin and Morrissey, 2011), local democracy and governance practices for inclusion (van den Dool et al., 2015) or how to address poverty and socioeconomic divisions in cities (Koonings and Kruijt, 2009). Both the Organisation for Economic Co-operation and Development (OECD) and the European Union (EU) map socio-economic differences (OECD 2015; OECD 2016; European Commission 2016) or look for sustainability indicators (Eurostat, 2016), and more qualitatively oriented social scientists and urban theorists focus on such issues as urban policies in the peripheries of cities (Dikeç, 2007), accessibility to green space and local environmental injustices (Wolch et al., 2014) and the role of public spaces in social conflicts and interactions (Hajer and Reijndorp, 2001; Wanjiku Kihato et al., 2010). Jane Jacob's book The Death and Life of Great American Cities (Jacobs, 2011) was first published in 1961, and since then, it has been an important international reference in this context because she tells a convincing story about how the built environment and social life are interrelated. More recently, urban planning researcher Susan Fainstein used empirical studies of Amsterdam, New York and London to propose the necessary condi- tions for "the just city" (Fainstein, 2010). She emphasized affordable housing and low-cost public transport, among other things. Of course, the specific approach to inclusion or social sustainability can differ if a city or a district is characterized by physically segregating barriers, large informal settlements, ethnic conflicts or extreme poverty, but a common denominator in research that explicitly deals with urban social sustainability is the need to define the concept and find the most useful indicators with which to measure it. This is regardless of whether it concerns the Nordics or other parts of the world.

A few examples from around the world illustrate the different ways planning for inclusion can be implemented: in Medellín, Colombia, the Metrocable transportation link improves accessibility for residents in poor neighbourhoods and helps create street life; in Austria, there are policies that encourage the supply of subsidized housing; and the participatory budgeting scheme that originated in Porto Alegre, Brazil has been an important source of inspiration for contemporary citizen participation practices all over the world.

Nordic cities are often cited as good examples of inclusion and social sustainability because of their accessible public spaces, small socio-economic differences, rights to housing and trust in local democratic governance structures (regarding trust, see, e.g. Ortiz-Ospina and Roser, 2017). For example, on the UN Habitat's "Prosperity Index", the Nordic capitals of Oslo, Stockholm, Copenhagen and Helsinki are all at the top of the list. The "Prosperity Index" includes measurements of quality of life, equity and social inclusion, and governance, all of which are related to inclusion. UN Habitat writes, "The strong integration and homogeneous balance of all the dimensions show that these cities have achieved a good synergy between urban planning, urban governance and finance for the collective interest. It allows them to be 'hubs' of prosperity thanks to the high production of goods and services within a safe and secure environment (...) Cities like Oslo, Copenhagen and Stockholm are doing well, as are the regions where they are located. With their relatively well-educated and fully employed populations, they base their economic momentum on a combination of factors, since they act as administrative and financial as well as cultural capital cities. Urban planning has had much more influence here than in any other region of the world" (UN Habitat, 2015). 


\subsection{The Healthy City \\ Linking social health and well-being to environmental health}

Nordic cities are clean. Almost anywhere in the city, people can breathe cool, fresh air and drink water directly from the tap or take a bath in the nearest harbour or lake. Cities in the Nordic Region have overcome urgent issues related to health in urban environments, such as unsanitary conditions, vulnerability to hazardous air and water pollutants and the accumulation of solid waste. The contribution of urban-based production and consumption to ecosystem disruptions and resource depletion has also been emphasized in addressing health-related issues. Thus, in Nordic cities, health is perceived as a broad issue that surpasses human health to also include care for the environment.

Health in urban environments is a complex issue that cuts across policy sectors. At the macro level, it includes spatial planning, land use and transportation infrastructure, while at the local level, the design, maintenance and use of buildings, public spaces and transport networks are also relevant (WHO, 2010). In this respect, the design and management of the built environment can encourage or constrain certain behaviours that are likely to influence air quality in urban areas. For example, planning can decrease the reliance on private cars by encouraging the use of public transportation, biking and walking, thereby enhancing health (people get more exercise) and the environment (less $\mathrm{CO} 2$ emissions). Gelormino et al. (2015) suggest that the complex relationship between cities and health can be divided into three aspects: (i) City - nature - health; (ii) City - social context - health; and (iii) City - behavioural aspects - health. The first aspect emphasizes the re-

C6 I feel that in general there is a responsibility towards the environment, and that we feel a responsibility for being a role model for others as well as learning from other cities and regions.

ÓLÖF ÖRVARSDÓTTIR, HEAD OF DIVISION, REYKJAVIK ENVIRONMENTAL AND PLANNING DEPARTMENT, REYKJAVIK CITY

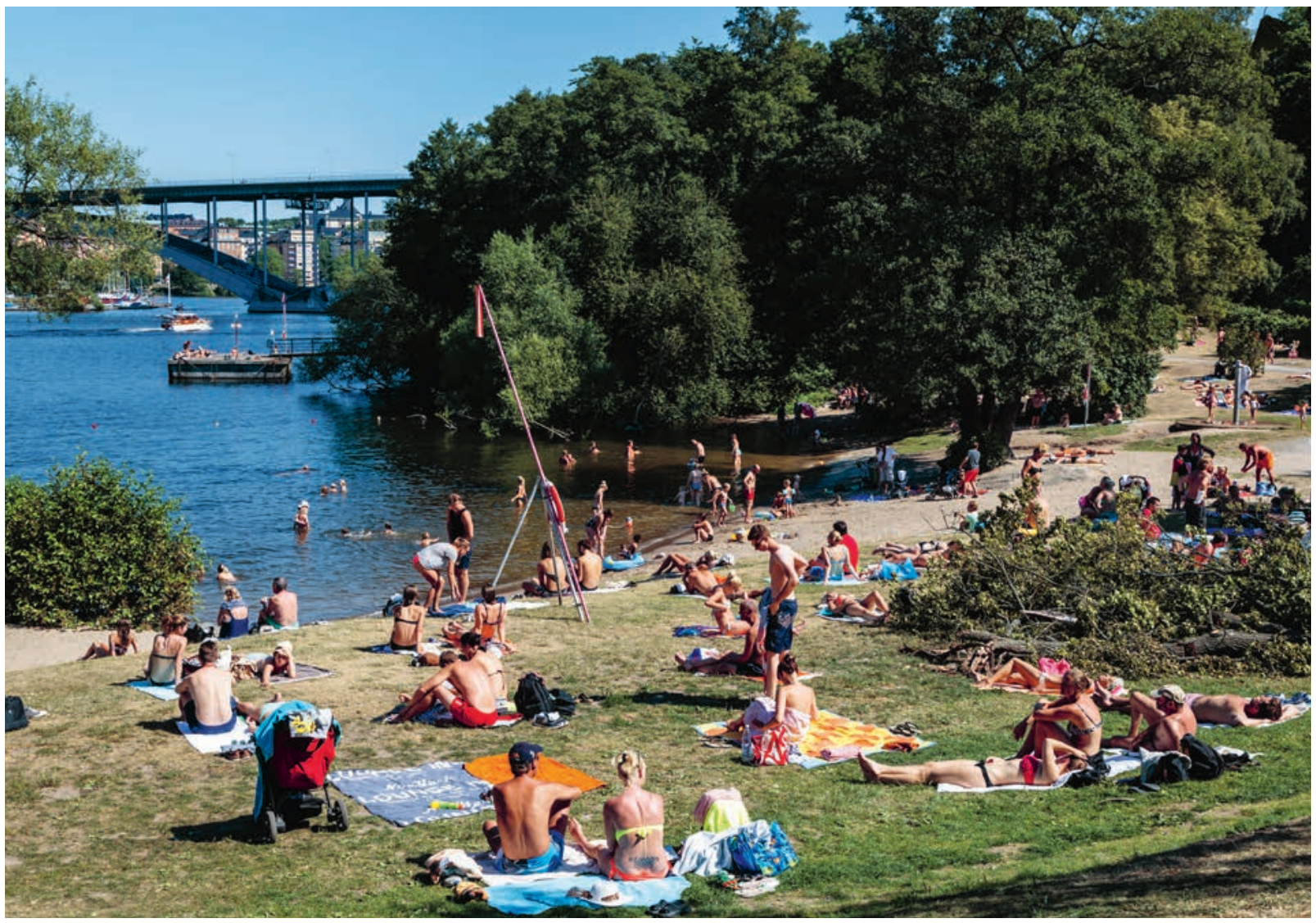

Långholmen, Stockholm. Source: Yadid Levy/Norden.org 
lationship between the natural and built environments, the second focuses on social norms that shape people's lifestyles, and the third addresses the differences in health conditions that emerge from individual behaviours. This characterization of the healthy city in the Nordic context acknowledges the inter-related nature of these aspects, but it prioritizes the relationship between city nature - and health, especially with respect to the importance of water quality, air quality and green spaces for peoples' health.

\section{The natural landscape is the underlying principle for urban development}

In the Nordic countries, spatial planning at different levels has encouraged the integration of nature in urban areas, positively influencing both human health and the health of ecosystems. The integration of blue-green infrastructures in urban environments underlies the logic of urban development of many Nordic cities. In Stockholm, $47 \%$ of the total area is non-developed land (e.g., green areas) and water (Egerö and Malmros, n.d.). This spatial pattern is also seen in Helsinki, where greenery covers over $40 \%$ of the city's land surface, forming a 'network of recreation areas' with finger-like patterns separating urban areas that have been encouraged to develop along railways and main roads (Söderström et al., 2015). Similarly, the Copenhagen Finger Plan maintains ecological corridors alongside the development of urban structures (Jorgensen, 2004). Reykjavik's spatial development also follows a plan that maintains a continuous forest and an outdoor recreational area at the edge of the urban growth area, which is called 'the Green Scarf' (Kristjánsdóttir, 2008). In these cities, the use of green edges and the protection of aquatic ecosystems have enabled the creation of rich biodiversity zones and enhanced spaces for recreation, exercise and social activities, thereby preserving nature and improving human physical and mental health. By mixing urban, green and blue structures, these spatial patterns have reduced air pollution, diminished the heating effect of grey structures and increased accessibility to green spaces, which has proven to have a positive influence on human health (Nilsson et al., 2011). The relationship between the natural environment and physical structures seems to have cultural value as well, as social health and well-being are clearly linked to environmental health, and access to nature is directly related to cultural issues.

\section{$\int\left\{\begin{array}{l}\text { Nordic cities focus on } \\ \text { well-being. }\end{array}\right.$}

MONICA VON SCHMALENSEE, CEO AT WHITE ARKITEKTER

Cities in the Nordic Region usually have a thriving relationship with their waterscapes. Water is highly valued and it gives people an opportunity to experience and enjoy nature. The waterfront of the Islands Brygge in Copenhagen was transformed from a polluted port into a vibrant urban environment. Technology and political will enabled the restoration of the water quality, creating a healthy place where people can swim in the middle of the city (State of Green, 2017). Project H+ in Helsingborg provided for the redevelopment of a harbour district into a residential and business area for more than 10,000 people. The project includes the modernization of water treatment plants and an innovative sewage system. These initiatives highlight the recreational value of water, increase social awareness about its importance for health and encourage care for and preservation of nature.

\section{Water quality, air quality and health}

Cities in the Nordic Region have widespread and equitable access to safe and affordable drinking water, as well as adequate sanitation for all of their residents. All urban dwellings are served by public water supplies and sewage systems. Nevertheless, some Nordic cities face water outbreaks because of critically low ground-water levels, which are most common between June and August (Guzman-Herrador et al., 2015). The use of digital technologies, such as sensors to monitor leakages in the water supply network, has helped, saving significant amounts of treated water while maximizing the distribution and treatment of wastewater (State of Green, 2017).

With respect to air quality, the overall level of pollution is relatively low in the Nordic countries (Norden, 2007). Nevertheless, because of the cold climate, Nordic cities occasionally experience worsening air quality. Unfavourable meteorological conditions often increase the concentration of pollutants in the atmosphere, and the cold climate and relatively short average driving distances in the cities contribute to a large number of engine cold-starts and higher levels of emissions (Norden, 2007). Recently, Oslo has experienced high levels of pollution, and Stockholm has also identified vul- 
nerable urban areas that might pose health risks to the population. Nevertheless, a diverse range of actions have been taken to improve air quality. In collaboration with industry and the authorities, the Norwegian Institute for Air Research has developed sensor networks that provide the population with real-time information about aerial contaminants throughout Norway (NILU, 2016). Ambitious investments in electric cars have made Oslo the world leader in switching to emissionsfree transportation (Hockenos, 2017). The city has also implemented large no-car zones and instituted rush hour fees for motorists, steep congestion charges and parking fees. Similar initiatives have been adopted in other Nordic cities, including Helsinki, which has converted inner city ring roads into residential and walking areas, and Stockholm, which restricts the use of private vehicles in vulnerable areas and has decreased the number of cars in the city centre through congestion charges.

Although human exposure to hazardous pollutants has been managed by soft and quickly implemented planning measures, many cities in the Nordic Region have a growing concern for the longterm health of the environment, which has been manifested through various planning measures. For example, Copenhagen has set the ambitious target of becoming carbon neutral by 2025 (Copenhagen Climate Plan, 2009) through such policies as greening transport (improving bike paths, investments in public transportation, etc.). Relying on a nodal cityscape that offers most of the facilities that people need, the Stockholm city plan aims to establish a walkable city of interconnected neighbouring districts (Stockholm City Council, 2010). Both of these development plans have transportation or land use policies that are likely to lead to better urban air quality and improve human health by encouraging physical activities.

\section{International outlook}

Silent Spring by Rachel Carson (1962) is often regarded as a milestone in the field of environmental health. This book warned of the effects of pesticides on wildlife ecology and human health, and by doing so, environmental health became strongly associated with the recognition and control of chemical exposure. This perspective on environmental health changed in the early 1980 s, when the "environmental justice" movement highlighted the connection between civil rights and environmental health. This movement powerfully influ- enced environmentalism and environmental health by documenting that vulnerable groups were often exposed to environmental hazards. In the following decades, trends such as rapid urbanization and the sprawling expansion of cities changed the focus of environmental health from just the chemical environment to built environments more generally (Frumkin, 2005). The need to integrate environmental and social sustainability dimensions has also strengthened the ties between issues related to health and built environments (Barton, et al. 2003).

Research in the field reflects the broad array of meanings that the term "urban health environment" covers, including studies that explore the role of urban design in health and well-being (Kleiner and Hor, 2016), uncover relationships between walkability and air pollution (Marshal et al., 2009) and examine liveability in cities through infrastructure innovations in energy, water and green infrastructure (Lennon et al. 2017), as well as through food systems linked with social, behavioural and policy changes (Milan Municipality, 2015). Nevertheless, the literature seems to suggest a divide between how developing and developed countries use the term. In developing countries, issues related to the "brown agenda", including poor housing conditions, lack of access to safe water and sanitation, and overcrowding, get most of the attention, whereas in developed countries, the "green agenda" emphasizes the importance of healthy environments for future generations; the prevention of overuse and the degradation of resources are also relevant (McGranahan and Satterthwaite, 2014).

Cities in different parts of the world are developing strategies and allocating financial resources with health as the goal of planning. For example, with the goal of "A Healthy City for All", the Vancouver City Healthy Strategy (2015-2018) includes policies in areas such as the fulfilment of basic needs (housing, water, sanitation, etc.), cultivating social connections and ensuring liveability now and into the future. Similarly, Manningham, Australia recently developed a Healthy City Strategy (2017-2021) that highlights inclusion, safety, resilience, connectivity and creativity as relevant issues for healthy urban environments. The initiative "Invest Health: Strategies for Healthier Cities" (2016) subsidized 50 mid-sized U.S. cities to develop strategies to improve the health and wellbeing of residents in low-income neighbourhoods. 
Increasing access to quality jobs, affordable housing and nutritious food, and reducing crime rates and environmental hazards are some of the action areas that the program covers. These examples all indicate that initiatives for healthy cities today are often quite broad and comprehensive.

Acting in six worldwide regions (Africa, the Americas, South-East Asia, Europe, the Eastern Mediterranean and Easter Pacific), the World Health Organization (WHO) has been promoting discussions and actions and driving research in the field. In 1987, the WHO launched the Healthy Cities Project in Europe with the participation of 11 cities. By 2009, at least 1300 cities in the European region were engaged in this program (Lafond and Heritage, 2009). Based on the understanding that human health and well-being are the fundamental purpose of sustainable development, the WHO European office developed the Healthy Urban Planning (HUP) initiative in 1997. This initiative recognized that the quality, equity and efficiency of urban environments profoundly influence health, and it became a reference tool for providing an evidence-based foundation for planning and policymaking (Barton et al., 2003).

The Nordic countries (Denmark, Finland, Norway and Sweden), the UK, the Netherlands, South Korea and United States lead research in regard to the impacts of physical urban environments on people's health and well-being (Nilsson, et al, 2011). When it comes to best practice, the capital Nordic cities also stands out. The winter sport facilities in Oslo (Oslomarka) and Helsinki and the cycle tracks and seaside areas, such as Amager Beach Park in Copenhagen are few examples. Concerning air quality, the Northern Europe has, in general, better conditions in comparison with other European countries (EEA, 2017). Particle pollutions, also called Particulate Matter (PM), are not an issue for cities in Finland and Sweden. Conversely cities in Denmark and Norway may experience problems with PM concentrations, depending on the local emissions and weather conditions (Rispling, et al 2016)

Healthy Urban Planning has been part of the agenda of national authorities in the Nordic countries. Municipalities in Denmark, Finland, Norway and Sweden are engaged in WHO networks for healthy cities (WHO, 2015). Gothenburg, Sweden, Horsens, Denmark and Sandnes, Norway have had good experiences integrating health into spatial planning policy and practice (see Barton et al.,
2003). Malmö, Sweden has developed good practices for using planning to facilitate human health (Malmö Stad, 2013). The initiatives reported in these cases show how the strong and autonomous role that the local level plays in Nordic planning systems more readily facilitates the integration of health practices into spatial planning than do the more centralized and hierarchical administrative structures of other planning systems.

\subsection{The Resilient City Adapting to climate change}

Nordic cities take the risks caused by human climate change seriously. Adaptation and mitigation actions, especially water issues such as more frequently occurring torrential rains and rising water levels, are integrated in multifunctional spaces.

There is a long tradition of climate and environmental monitoring in the Nordic Region (Morgen, 2009). As part of the Nordic countries' responses to climate change, energy policies have focused on the reduction of greenhouse gas emissions while also promoting sustainable urban development through the decoupling of emissions from economic growth. Between 1990 and 2011, the total Nordic GDP rose by $55 \%$ while emissions across the region were reduced by $9 \%$ (Norden, 2014). The Nordic countries differ in their projected climate change impacts, and their responses to climate change have differed according to their geographic specificities and economic structures. However, the Nordic countries have many commonalities,

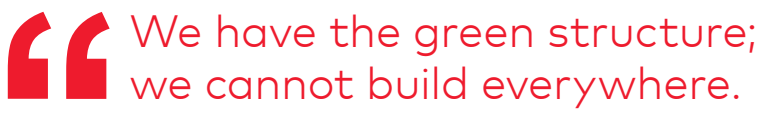
We have a policy to maximize all the different functions that green areas could have. One is the social aspect, spending time in green areas. Green areas also create shade, lowers the temperature and can absorb rain water. They are also important for biodiversity. A city could be the habitat for species that are vulnerable. We have a focus on balanced development.

BJÖRN HUGOSSON, HEAD OF CLIMATE UNIT AT CITY OF STOCKHOLM EXECUTIVE OFFICE, CITY DEVELOPMENT DEPARTMENT 


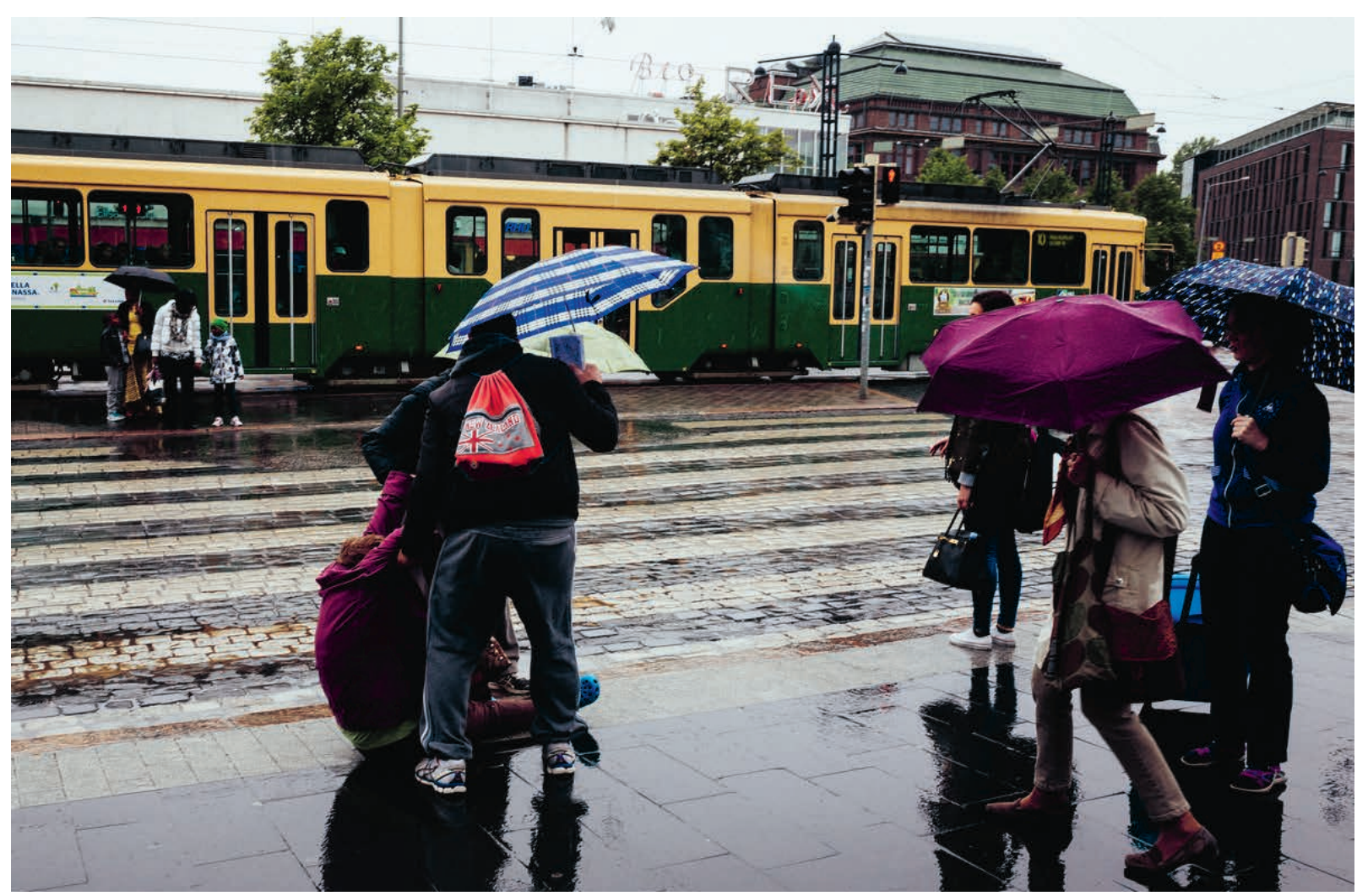

Rainy day in Helsinki. Source: Benjamin Suomela / Norden.org

such as similar legal frameworks, and they have been co-operating on climate change related issues for many years in Nordic Working Groups under the Nordic Council of Ministers (Scherbenske and Diș, 2011), as well as in larger regional groups, such as the Arctic Council and the Baltic Sea Region Programme.

The Nordic countries have also incorporated an integrative approach to climate change that emphasizes the interactions between mitigation and adaptation responses to climate change, which have usually been addressed in separate policy spheres and documents (Goodsite et. al., 2015). It has been recognized that adaptation and mitigation actions are mutually beneficial when considered together, rather than causing conflicts. The term "adaptigation" has been developed to describe the Nordic countries' integrative approach to adaptation and mitigation (Langlais, 2009).

\section{Coping with increasing rainfall}

According to various scenarios of climate change impacts, the amount of extreme rainfall could rise by up to $40 \%$ in Scandinavia and North-Eastern Europe (SMHI, 2017). More extreme heat and rain are expected to be the pattern with increased frequency and intensity. Surface water management will have to be adapted to climate change impacts such as increased precipitation (rainfall) and rising water levels in lakes, coastal waters and rivers. Because of growing urban populations, there is increasing pressure on water resources in terms of access, security, treatment, and scarcity. The opportunities and challenges of city densification ${ }^{6}$ and the uncertainties related to climate change impacts also create water-stressed cities. Therefore, one of the major areas of adaptation is water management, with a focus on flood management and sea level rise.

Hence, of particular concern for the Nordic countries with respect to climate change impacts are water-related issues, with increased precipitation patterns, a rise in sea-level and urban flooding projected by the IPCC (IPCC, 2014). Adaptation through planning, land use design and construction can help to reduce the negative impacts of climate change such as flooding, landslides and erosion. The most relevant responses for building resilient Nordic cities can be grouped under three themes: water management; the development of

6 The increase of hard surfaces associated with city densification can lead to cities being more vulnerable to increased precipitation caused by climate change. 
ecosystem services; and the design of multifunctional urban spaces that address storm-water, emissions and adaptation.

There are several examples of adaptation through planning and construction and initiatives that focus on resilience in cities in the Nordic countries. With respect to adaptation measures, effective water management is crucial, as water has the potential to improve the daily lives of people living in cities. For example, the Finnish Environment Research Centre increases the safety of people with the provision of 5-day flood warning maps that indicates vulnerable areas (SYKE, 2017).

Water management requires an integrated process that includes land use planning, infrastructure, energy generation and waste. In 2015, Stockholm adopted a new storm-water strategy to prepare for a $30 \%$ increase in precipitation by 2100 and to improve the quality of storm-water to reach the city's environmental quality standards. Stockholm's drinking water comes from Lake Mälaren, which is separated from the Baltic Sea by the Slussen Lock. Stockholm's largest climate adaptation project is the reconstruction of the Slussen Lock to allow it to release more water and prevent urban flooding (Stockholm Stad, 2017).

By rethinking the multiple uses of rainwater and seeing it as a resource to create beneficial urban green spaces, Denmark created synergies from investments and developed two tools. These tools are available online and can be used by diverse stakeholders such as Danish municipalities, utilities, consulting companies, architects, contractors and knowledge institutions to help them plan and prioritize their efforts. The first tool is a method developed by Water in Urban Areas for comparing expenses for building 'grey' vs. 'green' solutions. This method takes into account parameters such as the durability of the solution, environmental effects and visual and recreational qualities, as well as possible synergies with other planned construction projects (State of Green, 2016). The second tool, called 'SPLASH', was developed by the Danish Nature Agency to help calculate the socio-economic consequences of specific climate adaptation measures in local areas. SPLASH calculates the size of the investments needed to guard against a given rain event, and then shows the long-term economic gains from each suggestion, including the value of positive spillover effects (e.g., reduced costs of flooding damage, reduced water consumption, increased green areas, increased CO2 absorption) (State of Green, 2016).

\section{Integrating ecosystems services into urban planning}

The integration of ecosystem services into urban planning provides benefits by reducing emissions and developing preventative measures for climate change impacts. The Stockholm Biochar Project is another good example of developing a better city ecosystem. Biochar is a powerful soil conditioner that is considered a carbon sink because it decreases carbon dioxide levels in the atmosphere and retains water, air and nutrients in the soil. Through its production in Stockholm, it will create enough energy to provide heat and hot water for more than 80 apartments in the city (Stockholm Vatten och Avfall, 2017). When garden waste is converted into biochar and added to the soil, the landscape becomes greener and healthier and carbon is sequestered for thousands of years. Furthermore, by introducing biochar into tree and flower-beds, cities can increase local infiltration of storm-water, which enhances ground-water production and traps pollutants.

In the production of biochar, bio-oil and syngas can be extracted to be used for bio-fuel production, electricity and district heating. The Stockholm biochar project and existing municipal waste streams have been combined in a new concept in which public engagement and circular models for energy and material flows are promoted and stimulated.

One example of Denmark's approach to resilient urban planning involves an alternative look at land use. Tåsinge Plads has been referred to as Copenhagen's first climate change-adapted urban space, thereby making it Copenhagen's first climate-resilient urban space. Tåsinge Plads is a square that shows that rainwater can be used to create new recreational urban spaces. The square is designed as a multifunctional space that can handle rising volumes of rain at the street level. Tåsinge Plads is a living part of the urban environment that is designed to direct and hold back as much rainwater as possible. The landscape also slopes away toward an area at a lower level, where the storm-water gathers. The landscape is raised above ground level to provide space also designed in a way that visitors can enjoy it as a public space. The design of this square is a good example of water management in anticipation of extreme future 
rainfall events that contributes to a vibrant urban life (Klimakvarter, 2016).

There are many more examples to share and draw inspiration from. With respect to co-ordinating all these different efforts, a common Nordic adaptation strategy could be useful in helping to identify areas where a joint regional effort could achieve more than individual countries' actions, and provide a useful mix of top-down (regional strategy) and bottom-up (local examples) guidance (Scherbenske \& Diș, 2011).

\section{International outlook}

The concept of resilient cities has stimulated discussions and inspired books, articles, reports and initiatives by major institutions such as the United Nations and the World Bank. The International Council for Local Environmental Initiatives (ICLEl, 2013) and the Intergovernmental Panel for Climate Change (IPCC, 2014) highlighted the importance of urban climate adaptation and how it can contribute to building resilience and enabling sustainable development. With respect to resilience, cities are commonly referred to as complex adaptive systems (Batty, 2008; Godschalk, 2003; Mehmood 2016). After four decades of academic literature on urban resilience (beginning in 1973), the most recent definition of urban resilience includes the abilities of urban systems and all their constituent socio-ecological and socio-technical networks across temporal and spatial scales to maintain or rapidly return to desired functions in the face of a disturbance, adapt to change, and quickly transform systems that limit current or future adaptive capacity (Meerow et al., 2015, p.39).

"Governance", "climate change" and "city" seem to be the research hotspots in urban resilience (Pu and Qiv, 2016). There is a growing emphasis on enhancing the resilience of cities worldwide in the face of climate change and rapid urbanization. Future directions for research include a focus on ecosystem service, adaptive capacity and human-dominated ecosystems (Pu and Qiu, 2016). A great majority of the definitions of urban resilience highlight adaptability, flexibility or adaptive capacity (Eraydin et al., 2013; Bhamra et al., 2011).

The US and the UK are seen as the most productive countries in this field of research ( $P u$ and Qiu, 2016). Stockholm University is second in urban resilience research among the top 20 research institutions (ibid.).

Developing adaptive and sustainable infra- structure with a strong focus on resource efficien$c y$, water, waste and energy, as well as on mobility and transportation, has been at the forefront of the movement to create resilient cities. Examples from Europe seem to dominate city initiatives on sustainability. Germany has many good cases, such as HafenCity Hamburg, Kronsberg in Hanover and Emscher Park in Ruhrgebiet. In other parts of the world, cities such as Melbourne, Australia and New York, Seattle and Portland in the US have adopted good practices concerning urban transformation projects, focusing on how to effectively realize rapid structural and cultural changes within existing urban environments and communities by reconfiguring urban form and public spaces.

Community involvement has also been identified as an important ingredient of resilient cities (McCormick et al., 2013). Semarang in Indonesia, San Francisco in the US, Montreal in Canada, Thessaloniki in Greece, and Porto Alegre in Brazil have engaged their national governments, ministries and local authorities to embed resilience thinking into national plans and priorities (Resilience in Action, 2016).

The capitals and other big cities of the Nordic Region provide good examples of water and waste management strategies and the design of multifunctional spaces. Roskilde and Copenhagen in Denmark, Stockholm, Sweden, and Bergen and Fornebu in Norway are a few of the cities in the region that have adopted urban resilience strategies (State of Green, 2017).

Several Nordic countries have developed initiatives to showcase and export innovative Nordic solutions for resilient cities. The Nordic Built Cities Challenge is one example of this type of initiative.

\subsection{The Compact Green City Striving for densification and containment while preserving green infrastructure}

Across the Nordic Region people live closely together in densely populated cities that provide rich opportunities for human interaction and busy social lives. People also have easy access to nature and green open spaces within built-up urban environments. These green spaces are viewed as essential in promoting biodiversity and improving the health, living conditions and quality of life for Nordic citizens living in urban areas. Indeed, Nordic cities are widely known for their nature, greenery and clean environments. Nevertheless, they remain among the largest sources of greenhouse 


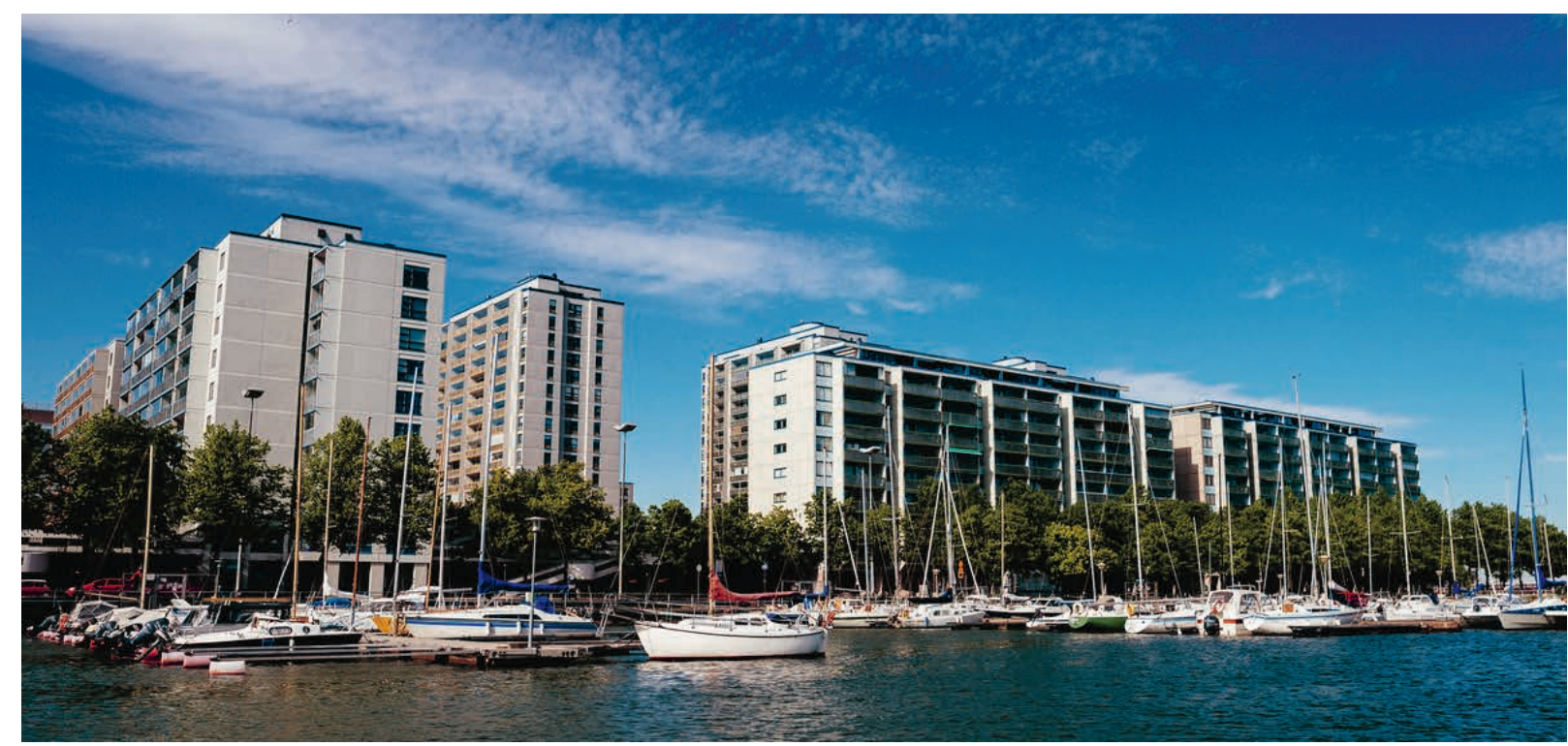

Architecture Merihaka, Helsinki. Source: Benjamin Suomela/Norden.org

gas emissions because of the heated homes and transportation systems. To combat the problem of road traffic, urban policymakers have long advocated for more compact cities.

\section{The potential conflict between mitigation and adaptation}

The EU has identified urban sprawl as a serious planning problem and advocated the development of more compact cities as the only solution (Fertner et al. 2016). Within its thematic strategy on the urban environment, the European Commission recommends better co-ordination between transport and spatial planning, along with the development of more compact settlements (European Commission, 2006). A key objective of the Work Programme for an Urban Agenda for the EU is to ensure that any changes in urban areas respect the environment and improve the quality of life of citizens. This chapter examines how to limit urban sprawl by making cities more compact through the development of brownfields and green spaces.

Densification as a means to mitigate climate change is not without its problems. Greenhouse gas emissions must be reduced so that temperatures stop rising, but this necessary process takes a long time and requires much greater unity among and determination of world leaders than has so far been possible to achieve. At the same time, it is important that we adapt our cities to make them less vulnerable to extreme climatic situations in the future.

\section{Closeness to and under- standing of nature. We} manage to bring nature into the city. In Stockholm, closeness to water and nature, in Finland closeness to forest. These natural elements are well integrated into urban development so it is quite a contrast to the urbanity you find outside the Nordic region.

\section{TINA SAABY, CITY ARCHITECT, COPENHAGEN}

Increasing density in an attempt to reduce energy consumption could lead to the loss of green spaces within cities and the vital ecosystem services that they provide (Niemilä et al., 2011; Elmqvist et al., 2013). For example, an increasing number of heavy rainstorms would cause more frequent problems with flooding, as there is a greater risk of flooding when there are insufficient permeable open green spaces for water infiltration. Also, if average temperatures change in the future, the urban heat island effect is likely to exacerbate more frequent temperature extremes in urban environments.

A tension exists between the need to keep cities green and reducing greenhouse gas emissions, which creates a conflict between measures for adaptation to and the mitigation of climate change. The potential answer to this problem lies in a combination of these two seemingly conflicting properties. 


\section{Nordic cities have found a good balance}

The challenge is to create a city that is both dense and green: the compact green city. It seems that Nordic cities have found a sound balance between the compact and the dispersed, which is why woods and water are key ingredients, even in our largest Nordic cities.

Urban containment, managed through a distinct boundary between urban and rural land use, is a common strategy for urban growth management and for achieving sustainable development that is focused on efficient land use and the preservation of rural functions, such as ecosystem services (Nilsson et al., 2014). Nordic cities are at the forefront of green infrastructure planning and management.

Copenhagen's regional plan from 1947, the socalled Finger Plan, is an example of combined urban transport, land use and open space planning. Urban development has taken place along transport corridors, "the fingers". An important part of this strategy is the near-to-station-principle, which means that, whenever possible, new working places should be located close to public transport. In between the fingers, open spaces are preserved as green wedges forming an overall green infrastructure. The original vision behind the Finger Plan is still the principle for the future development of Greater Copenhagen. Another attempt to preserve the urban green infrastructure is the establishment of National Urban Parks. The first National Urban Park was established in Stockholm in 1995, Ulriksdal-Haga-Brunnsviken-Djurgården, but the idea had its greatest success in Finland, where so far the government has approved eight National Urban Parks, such as those in Hämeenlinna or Turku.

\section{Brownfields turned into attractive residential areas}

Nordic cities prevent urban sprawl by reconfiguring existing structures rather than building new ones (Braae, 2015). Attempts have been made to make the existing built environment more compact through the regeneration of brownfield sites, the transformation of old harbour areas, retrofitting existing housing areas and revitalizing certain sections of inner cities and urban areas. Furthermore, underutilized urban areas have been developed for high-density housing, serving to increase population density and promote the liveability of urban spaces.
Attractive newly built residential areas in city centres, such as the Western Harbour in Malmö, Hammarby Sjöstad in Stockholm, and Pilestrædet Park in Oslo, are all regarded as pioneering examples in this field. These developments rest on a solid Nordic city building tradition whereby new residential areas were constructed on natural land close to the forests in Finland, Norway and Sweden, and low and density housing in Denmark. Urban districts of Tapiola in Espoo near Helsinki, Gärdet in Stockholm, and the Fredensborg Houses outside Elsinore are also examples of this tradition.

One way to make certain that future cities remain green enough is to ensure that authorities require a certain proportion of greenery in new settlements. In a pioneering project in Sweden, the planning authorities in Malmö required a green space factor of 0.5 for the expansion of Western Harbour-that is, a fifty-fifty relationship between sealed soil and green space in the new area. By specifying an index instead of formulating detailed rules, the authorities managed to safeguard greenery in the area, with the flexibility of letting construction companies find innovative solutions themselves, including ideas such as green roofs and allotment gardens.

In the Nordic building tradition, care for nature is a basic value. Buildings located in forests and other natural surroundings are popular in Norway, Sweden and Finland. Nordic construction companies have developed great skill in preserving trees and natural vegetation much closer to buildings than what was normally done in engineering practice. In situations where there is no natural vegetation, it has become common practice to plant the vegetation years before the development takes place, which is a tradition in Denmark, where building in forests is not allowed.

\section{International outlook}

Research on compact green cities is dominated by researchers from Asia, most of whom are from China. According to a 2015 review, 39\% of all scientific articles on the subject were published in China (Haaland and Konijnendijk, 2015). Europe accounted for $31 \%$ of the published research, followed by Australia with 19\%, and, somewhat surprisingly, North America, which only contributed $9 \%$. South America and Africa accounted for $1 \%$ each. Of the European countries, the Nordic countries are among the most prominent, especially if 
we consider participation in key international research projects such as PLUREL and Green Surge in addition to scientific publications.

The Nordic Region's leading position is further consolidated when we look for good examples of compact green cities. In the parts of the world with the fastest urbanization, such as India and Africa, urbanization often occurs at the expense of green spaces and other urban qualities. China is an exception here, as urbanization typically includes the development of the urban green infrastructure. Examples of cities that are considered green despite having very high population densities include Hong Kong and Singapore. In North America and Australia, they are struggling to adapt scattered cities characterized by urban sprawl into more sustainable structures. Australian cities such as Brisbane and Adelaide, as well as cities such as Vancouver and Seattle in North America, have taken the lead in this development.

In Europe, there is a clear gradient from the south and east to the west and north such that we find the best examples of compact green cities in Northern and Western Europe. The capitals of the Nordic Region, as well as second-tier cities such as Aarhus, Bergen, Malmö and Tampere, are well-known internationally. Otherwise in Europe, it is mainly in the Netherlands (The Hague, Amsterdam and Utrecht) and Germany, with the transformation of the Ruhr District and urban renewal in Hamburg, that good examples are found, but there are also good examples in France (Montpellier and Lyon) and Spain (Barcelona and Valencia). On the other hand, the development of compact green cites in Britain has been rather poor, mainly because of limited public funding, with similarly poor development in Eastern Europe, where declining populations and weak public governance of urban development also have contributed to degrading urban environments.

Thus, the ability to combine urbanism and sustainable construction with the conservation and development of green cities is an unambiguous strength of the Nordic Region, both in research and in practice.

\subsection{The Mobility City Providing safe and clean transport alternatives}

In Nordic cities people can move fairly easily, quickly and safely. Nordic solutions for intelligent public transport and cycling are at the forefront internationally. In particular, urban planning concepts in

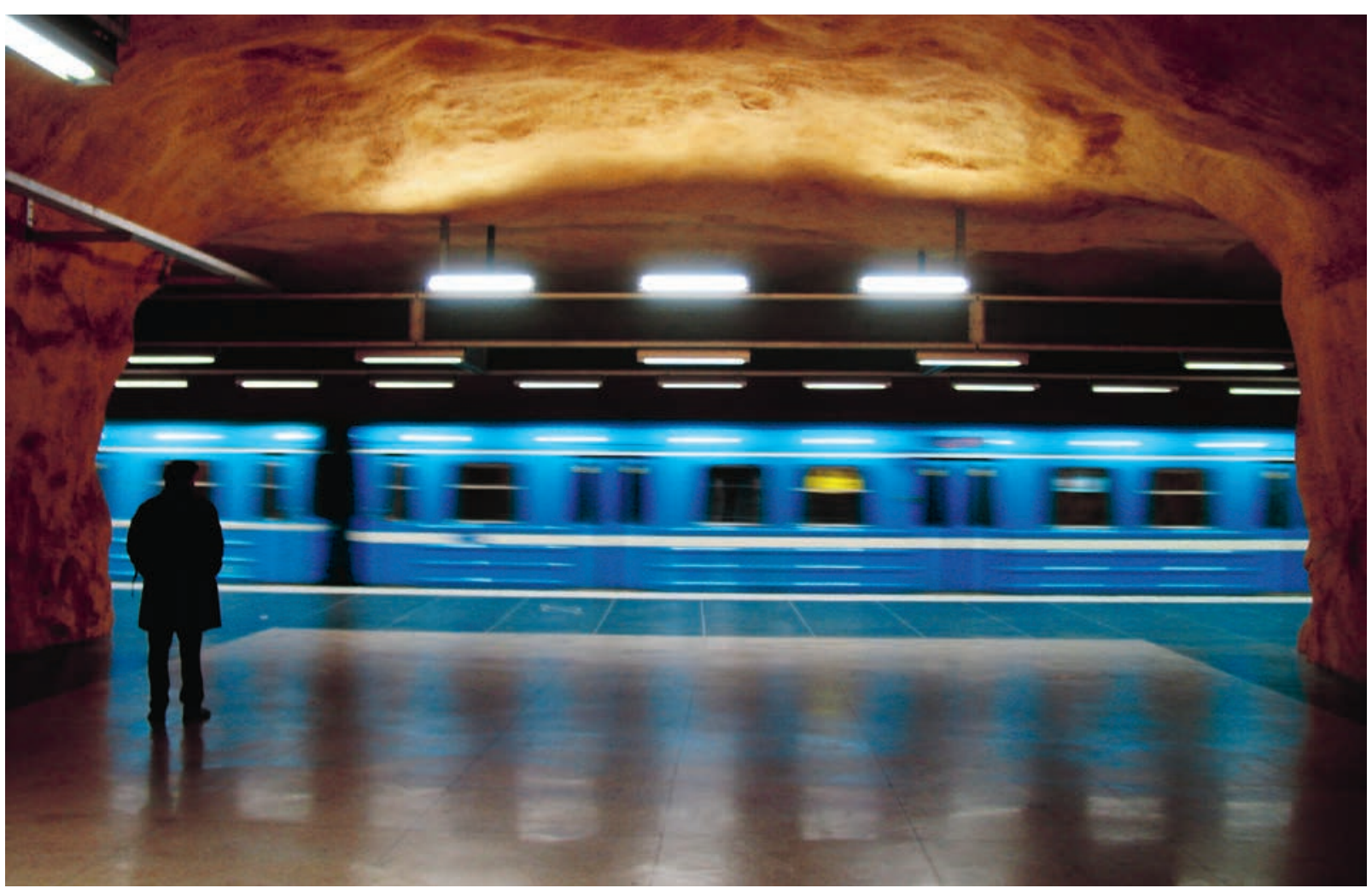

Subway in Stockholm. Source: Magnus Fröderberg/norden.org 
69 Oslo has decided to have an inner city free of private cars, which means more space for pedestrian and city life. The new main avenue Dronning Eufemias gate of Oslo has space for bikes and trams, $10,000 \mathrm{~m} 2$ of new sidewalks, and 600 trees for the new inner city.

RAINER STANGE, PARTNER/PROFESSOR/ LANDSKAPSARKITEKT MNLA

Nordic cities emphasize cycling and walking and that favour public transportation instead of private cars, to benefit both the environment and people's health.

Nordic cities and urban regions are characterized by significant population growth, increasing population densities, relatively compact spatial structures and high transport demands (Næss, 2012), which creates challenges for the organization of intra-urban mobility. The urban form and the resulting urban spatial structure of Nordic cities directly influence mobility choices and travel behaviours. The majority of Nordic cities can be seen as adaptive cities, that is, cities in which, "urban transit is the dominant element of mobility and the urban landscape has been adapted to service the general needs of urban mobility" (Rodrigue, 2006: 188).

Mobility is a key aspect of sustainable urban development. Sustainable urban mobility is constant challenged by urban dynamics that influence mobility (changes in transportation infrastructure, means of transport, mobility needs, density of people and activities, etc.). Sustainable urban mobility is defined as "sustainable movement of people and goods within an urban geography", where sustainability "contributes to cities being able to function in a way that minimises air and noise pollution, contributes toward targets to reduce $\mathrm{CO} 2$ emissions, promotes economic development of the city, enables good levels of mobility for people and goods, and is affordable to users and taxpayers" (Booz \& Company, 2012: 1).

Banister (2008) listed four types of actions that contribute to sustainable mobility: land-use policy measures; transport policy measures; technological innovations; and reduction of the need to travel. The first three of these actions can be illustrated within the context of Nordic cities.

\section{Long tradition in Transit Oriented Development}

Land-use policy measures for sustainable mobility try to reduce distance travelled in general, as well as limit the use of cars. These measures focus on both mixed land-use (as opposed to the separation of activities in space) and increasing the densities of people and activities. An example of one of these measures is Transit Oriented Development (TOD), which offers more transportation choices (more alternatives to the use of private cars), fewer and shorter trips, lower personal transportation costs and easier access to daily needs. TOD is characterized by an efficient public transportation with supply of frequent travel opportunities, high quality public spaces with user-friendly environments for cyclists and pedestrians, a high density of development around public transport stations, a limited number of parking spaces, and a mix of residential, office and retail uses. The development of transit corridors with strict land-use rules around the stations (e.g., Copenhagen's Finger Plan), and the creation of a subway network through the sale of publicly owned land along the network in Ørestad are two well-known examples. The construction of dense mixed land uses along a new light rail line took place south of the Stockholm city centre with the establishment of Hammarby Sjöstad and Liljeholmenskayen. Mixing uses in transport hubs by offering cultural and retail services along with mobility services is also a measure that promotes sustainable urban mobility (e.g., the re-development of the central stations in Odense and Uppsala). High priority and strict rules keep green belts in and around urban corridors in Nordic cities (Copenhagen, Stockholm).

\section{Favouring green mobilities}

Transport policy measures for sustainable mobility try to influence the modal shift through the reduced use of private cars and the increased use of green means of transport. Some Nordic cities have reduced car use with dissuasive measures, such as high parking fees, road pricing and congestion taxes (such as in the city centres in Stockholm and Oslo) and the reduction of speed limits for cars in certain areas. In parallel, they have also promoted more environmentally friendly means of transport (walking, biking and public transport) by dedicating more space to these activities. The idea was that urban streets should not be strictly for automobile traffic; they should also be safe public envi- 
ronments for people, cyclists and public transport (e.g., Nørrebrogade in Copenhagen). Bicycle infrastructure development played an important role in this modal shift, with dedicated paths, cycling highways and parking opportunities, as in Lund, Odense and Kristiansand for instance. Facilitating the combination several modes of transport is also part of sustainable development, such as co-ordinating bicycling and public transport (e.g., parking at train stations, sections dedicated to bikes in regional commuter light rail trains in Copenhagen).

\section{Intelligent transport solutions}

Technological innovations for more sustainable mobility try to provide more efficient and less polluting transportation modes. Emblematic initiatives include the development of self-driving cars (e.g., the innovation programme Drive Sweden, which includes national agencies, research institutions, public authorities and private companies), CO2-neutral major bus lines (e.g., line $5 c$ in Copenhagen), access to public transport for all (e.g., Stockholm), and mobility as a service (MaaS), which involves the integration of various forms of transport services into a single mobility service that is accessible on demand. Maas has recently emerged as a new way to promote intermodality and reduce car ownership. There are several types of MaaS in Nordic cities (Swedish ICT AB, 2016). Car-sharing is the most developed type of MaaS in Swedish cities, an example of which is Sunfleet, which was developed by Volvo, who owns both the car fleet and the platform. There are also combined mobility services that integrate options from different transport providers (public transport, taxis and rental cars) into a single mobile service and unified invoicing. For example, Helsinki Regional Transport, in co-operation with the Finnish

\section{Cur focus on Mobility and 4 accessibility in urban planning contributes to a higher quality of life. It is easy to get around, and through the way we build cities, public transportation is very efficient. Also, at least in Denmark, bicycling is a huge benefit for public health as well.}

KLAUS LEHN CHRISTENSEN, DANISH CLEANTECH HUB - NYC company MaaS Global, was the first capital region transport provider to offer Maas services to its customers. Finally, Rejsekort, an electronic ticketing system for travelling by bus, train and metro, is another example of Nordic innovation in the mobility sector. It unifies a number of transport operators, travel zones, ticketing systems and discount schemes into a common system that allows users of public transport to travel locally, regionally and nationally within Denmark using a single ticketing system.

\section{International outlook}

Sustainable urban mobilities are enabled by characteristics of the urban structure, socio-economics, attitudinal and cultural factors, strategic transport networks and the price of travel (Hickman et al., 2009). A number of these characteristics have been included in investigations of sustainable urban mobilities in cities worldwide, as illustrated by the three studies described in this section.

Capital cities and large urban areas in Western Europe represent the upper ranks of sustainable urban mobilities (Cebr, 2017; Copenhagenize Design Company, 2017; Little, 2014; UITP, 2015). Other highly ranked cities include large cities in microstates in Asia, such as Singapore and Hong Kong. These European and Asian cities have in common a well-developed infrastructure of environmentallyfriendly transportation modes (e.g. bike path networks), shared vehicle fleets (e.g. electric cars and bike sharing systems) and advanced digital mobility platforms. The cities have also reached (or are expected to soon) ambitious targets for sustainable urban mobility, such as achieving zero-emission transportation solutions.

These studies highlight two regions of the world that face more challenges than others, the Middle East and Africa. Cities in the Middle East are challenged mostly because of their relatively low population densities and high per capita car ownership. However, several cities have set ambitious targets for zero emissions (e.g. Abu Dhabi). Cities in Africa lack mature urban mobility systems, which presents many challenges for sustainable urban mobility, and they typically do not have zeroemission targets, or they are low priority (e.g. Cairo).

In terms of their sustainable urban mobilities, cities in the Nordic Region are top global performers. Four recent publications highlight the mobility performance of Nordic cities. The Future of Urban 
Mobility 2.0 report (Little, 2014) assesses the mobility maturity of 84 cities and summarizes their performance with the so-called Urban Mobility Index (Cebr, 2017). Three Nordic capital cities are in the top 10, and Hong Kong was ranked first. Stockholm was second thanks to a high rate of public sector initiatives, low transport emissions and well-developed car sharing systems. Copenhagen was ranked fourth, with the safest urban mobility system, a dense cycle network and a low rate of car ownership, among other factors. Helsinki was ranked ninth, partially because it has a high use of environmentally-friendly transport modes and short commuting times (Oslo and Reykjavik were not part of this study). The Mobility in Cities Database (UITP, 2015) highlights how Oslo is one of the global cities with the most promising changes in urban mobility patterns in the last 20 years. For instance, the number of trips made by public transport increased at a faster pace than the population in Oslo, and at a faster pace than in cities such as Vienna and Berlin, but at lower pace than in Geneva and London. The Urban Mobility Index (Cebr, 2017) shows progress towards the goal of sustainable urban mobility in 35 global cities. This report includes two Nordic cities, Oslo and Copenhagen. The former city holds the first rank in this index, which can be attributed to its fruitful efforts to reach zero emissions; it is estimated to have achieved $80 \%$ of this goal to date. Copenhagen is fourth, with a value of $69 \%$. Finally, several Nordic cities are often mentioned as good examples of bicycle-friendly cities. As shown by the Copenhagenize Index (Copenhagenize Design Company, 2017), the city of Copenhagen is ranked first ahead of two well-known bicycle-friendly cities in the Netherlands, Utrecht and Amsterdam. Malmö has consistently ranked highly over the years, whereas both Helsinki and Oslo are new in the top 20, and Stockholm has not made the top 20 since the 2013 index.

Capital cities in the Nordic countries are among the global leaders in sustainable urban mobilities. A long tradition in land use and transportation planning, ambitious targets set by local governments and the environmentally-friendly commuting habits of its residents have contributed to the strong performance of the Nordic capitals.

\subsection{The Low-Carbon City Transitioning from fossil fuels to bio a based economy}

Nordic cities show that it is possible to decouple economic growth and $\mathrm{CO} 2$ emissions. Since the late 1990s, despite a steady growth in GDP, Nordic cities have managed to keep $\mathrm{CO} 2$ emissions at a constant or even reduced level thanks to improved energy efficiency and increased use of bio-based and renewable sources. In Iceland in particular, innovative solutions have been developed for geothermal energy, and the Danish, Finnish and Swedish are known for their state-of-the-art solutions for district heating.

C6 Thanks to progressive building codes, new buildings have a very high energy efficiency standard. We don't even think about it, it is a given. Functional design, aesthetic houses, amazing urban planning. It looks great, and it is very energy efficient.

KLAUS LEHN CHRISTENSEN, DANISH CLEANTECH HUB - NYC

Urban areas are home to approximately $85 \%$ of the Nordic population. Capitals such as Oslo and Stockholm are among the fastest growing cities in Europe. Considering the various aspects of daily urban life, such as housing, mobility, recreation and the economy, it is clear that energy demands and greenhouse gas emissions are concentrated in cities. However, this also implies that cities collectively offer the greatest potential for reducing the climate impact of human activities and promoting sustainable development. This is the essence of the low-carbon city concept, which describes the actions and responsibilities that cities assume by pursuing carbon neutrality in an integrated way, together with urban resilience, a green economy and the development of green infrastructure (ICLEI, 2017).

The ability of cities to reduce their emissions is chiefly an energy issue, and there are three main areas in which energy use and emissions can be reduced in cities: the energy performance of buildings; mobility and transport; and the continued development of a low-carbon energy supply. Each of these aspects is particularly important in the Nordic Region. 


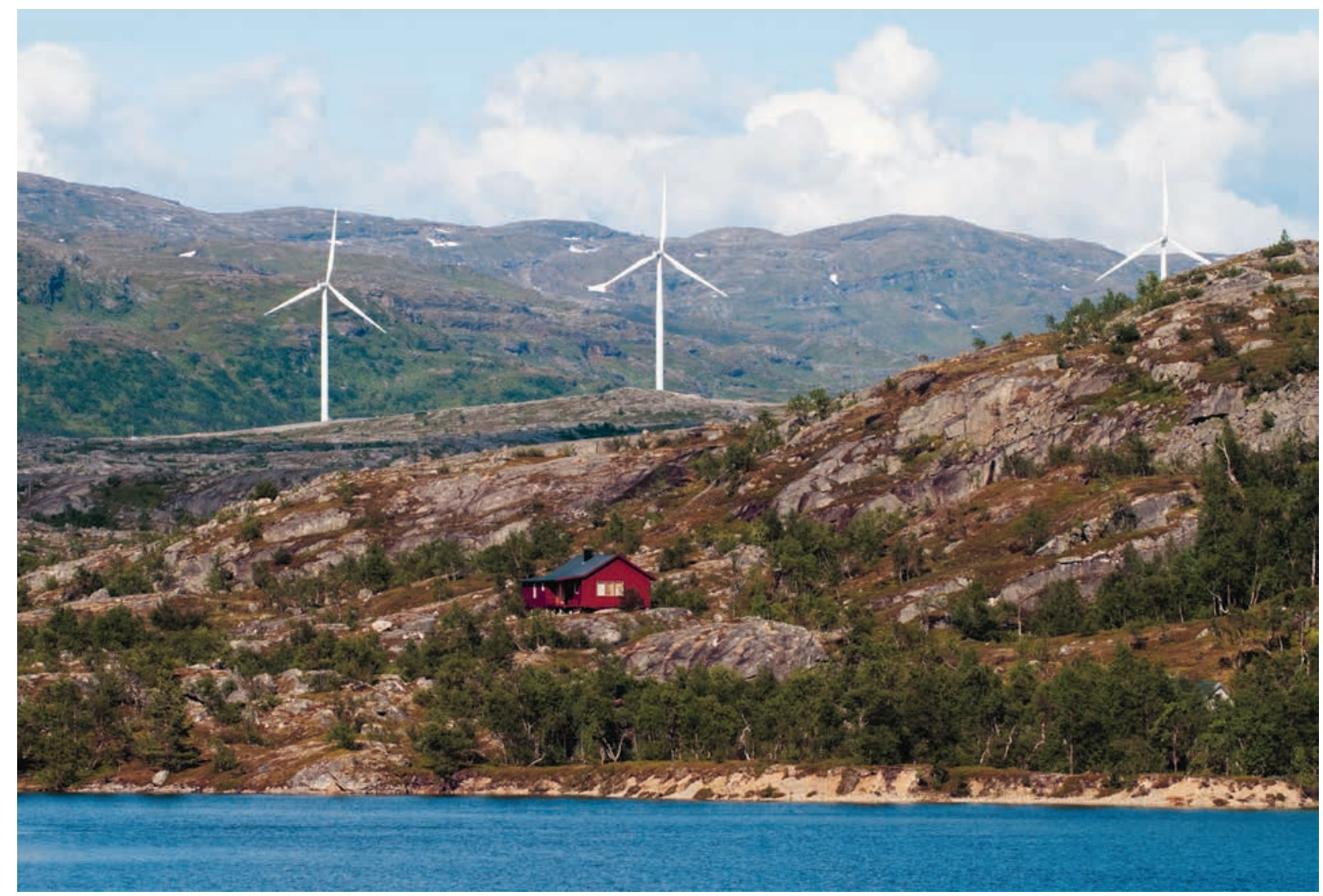

Wind turbines, Nordland Norge. Source: Johannes Jansson/norden.org

\section{Energy efficiency in buildings}

In 2013, buildings were estimated to be responsible for $43 \%$ of our energy consumption, which is attributable to the large stock of poor energy-performing buildings built in the 1960s and 1970s, as well as our cool climate and larger than average living spaces (NER, 2016). Many Nordic cities have ensured that the new construction of green buildings will exceed the standards set by national authorities, and construction and design firms such as Skanska have become world leaders in green building. The city of Stockholm took many steps to implement green building and green urban planning during the development of Hammarby Sjöstad, and many of these principles are being used in the current development of the Stockholm Royal Seaport. Similarly, Ny Karolinska, one of the largest construction projects in Europe, recently received the LEED Gold certification for its energy performance standards.

Although the performance of new green buildings in the Nordic Region is strong, continued improvements are required in existing structures. Approximately $70 \%$ of the estimated building stock for 2050 has already been constructed, including the extensive supply of modernist apart- ment housing that is prevalent throughout larger Nordic cities. Further investment in deep energy retrofitting with improved standards is needed to transform the current poor performance of these buildings. Existing Nordic construction technologies can be pursued further, with a continued orientation toward the global construction market.

\section{Low carbon solutions for transportation}

The mobility and transport sector is the second key dimension of the low-carbon city. The core aspects of reducing transport emissions include strategic densification and good land use planning, as pointed out in the compact-green and mobility chapters. For example, Stockholm's Walkable City Plan promotes car-free, low-carbon alternatives, and Copenhagen's Finger Plan is a global example of how an effective land use plan can promote sustainable transport solutions such as rail transport, cycling and walking. In fact, all of the Nordic countries have worked extensively to develop public transport, cycling, walking, electric vehicles, and alternative fuels.

However, like many cities throughout the world, the historical footprint of Nordic cities is still with us. The predominance of the private car 
66 The political process in the seventies in Denmark meant that there was a consensual decision to say no to nuclear power. As a consequence, wind power was introduced relatively early. It sped up the green transition tremendously.

KLAUS LEHN CHRISTENSEN, DANISH CLEANTECH HUB - NYC

and the associated urban sprawl is extensive in all large Nordic cities, as are the associated environmental challenges, including carbon emissions (EEA, 2006). Although $85 \%$ of the Nordic population lives in urban areas, $60 \%$ of this population lives in urban areas with fewer than 100,000 people (NER, 2016). Therefore, Nordic cities are characterized by distance barriers both within and between them. These factors suggest that the transport sector is the greatest challenge facing the Nordic Region for reaching carbon neutrality by 2050 (NER, 2016). Thus, an integrated urban strategy that bridges technological innovation, urban planning and behavioural change is necessary. For example, in a recent article titled "Unless we share them, self-driving vehicles will just make traffic worse", Roberts (2017) describes how the transport sector is facing three main revolutions: (i) Electrification - toward electric vehicles; (ii) Automation - toward self-driving cares; and (iii) Ride-sharing - toward fleets of shared cars, vans and buses.

The concept of ride-sharing highlights how it is possible to use new technologies more or less efficiently and that behavioural norms regarding transport need to be adapted (Roberts, 2017). However, Nordic cities are making progress. Oslo has extensively developed charging points for electric vehicles, and it recently announced that it will be a car-free city. Stockholm is planning a similar car-free strategy for significant portions of its city centre, and an extensive hybrid, self-driving vehicle pilot project is underway in Gothenburg. These examples highlight how the low-carbon urban mobility strategy will become increasingly multimodal, and suggest that the existing divide between "public" and "private" transportation will continue to narrow.

\section{Renewable and smart urban energy systems}

The third key dimension of the low-carbon city concerns the urban energy system, which is seen as a network of energy flowing throughout the Nordic Region and abroad. The Nordic low-carbon city will continue to be a net consumer of energy, and will therefore depend on advances in the energy sector, both within and outside of cities. However, the Nordic Region is fortunate in that its energy supply already has a high share of renewables, good development of district heating and modern biomass. Thus, even though Nordic residents consume more energy per capita than the EU average, the associated CO2 emissions are $50 \%$ lower than average (NER, 2016).

According to the recent report, "Nordic Energy Technology Perspectives" (NER, 2016), the development of solar photovoltaic energy will provide an opportunity to further decarbonize the energy supply; however, the greatest savings will be achieved by decarbonizing urban transport (described above), and especially by decarbonizing the supply of heat for buildings. Therefore, fourthgeneration district heating technology (4GDH) will be a core component of the future low-carbon city.

4GDH includes low-temperature heating supplies, improved heat transmission infrastructures, heat recycling, and building innovations such as smart metering, floor heating and local heat exchanges for hot water heating. Combined with smart energy technologies such as variable renewable technologies, energy storage and intelligent control systems, we can see that 4GDH and smart urban energy systems encompass a wide range of technologies that need to be co-ordinated. From a broader perspective, it is clear that this concept is designed for future urban energy systems that further integrate district heating with the electricity and transport sectors for optimal efficiency of the system (Lund et al., 2014). Thus, the integrated nature of $4 \mathrm{GDH}$ is an illustration of a future Nordic smart urban system at large, a system that will require further investment in both product and process innovation across the spectrum of existing opportunities.

All of the Nordic capitals have ambitious targets to reduce greenhouse gas emissions, and most of them aim to achieve carbon neutrality. These policies will require continued investment in technological development and efforts to adapt consumer behaviour to ensure that new technologies are used efficiently. With these develop- 
ments, Nordic cities can continue to be low-carbon innovation hubs and capitalize on their success in the global market.

\section{International outlook}

The low-carbon city is an integrated concept covering the energy, land use, mobility, housing and even the industrial sector. This topic has been researched intensively in urban planning and policy. A recent "low-carbon city" search using Scopus ${ }^{7}$ revealed 4,457 articles $^{8}$, of which $31.0 \%$ came from China, 31.6\% from Europe and 25.6\% from North America. The UK is the dominant country in Europe ( 145 articles and $23.3 \%$ of the European total), followed by Italy (71) and Germany (60). The Nordic Region features prominently, with 31 articles from Sweden, 30 from Finland, 13 from Denmark and 8 from Norway. European and global networks dealing specifically with low-carbon cities are also key contributors to both knowledge of cities and progress in planning and policy. These networks include the European Union's Covenant of Mayors and Local Governments for Sustainability (ICLEI).

The low-carbon city has recently developed into a mainstream concept in the broader field of urban sustainability. In terms of academic discourse, knowledge growth peaked in 2014, when 525 scientific journal articles were published, compared to 43 articles in 2000, 105 articles in 2005 and 235 articles in 2010. Our awareness of the low-carbon city has clearly grown profoundly in the last seven years.

In terms of the research theme, $25.7 \%$ of all articles dealt with eco-engineering as a main subject area, particularly those from Asia, and specifically China. Examples include industrial symbiosis in Asian cities (Fujii et al., 2016) and industrial emission abatement (Wang, 2014). Other common themes include issues of general modelling and monitoring for supporting low-carbon city planning and policy responses (Huisingh et al., 2015; Tan et al., 2017; Calderon \& Keirstead, 2012; Yin et al., 2012) and integrated perspectives of land use, transport and built environment (Ness \& Xing, 2017; Lehmann, 2012).

The research themes and implementation activities in the Nordic context also emphasize the integrated nature of the low-carbon city.

\footnotetext{
7 Scopus is the largest abstract and citation database of peer-reviewed literature.

8 Search of low-carbon city in article title, keyword and/or abstract.
}

The transport sector is a core theme, especially in relation to sustainable urban mobility and the development of electric and self-driving cars. Indeed, the world's largest pilot project in autonomous driving is currently underway in Gothenburg (Gothenburg, 2017). Urban land use planning that promotes the low-carbon city is a well-established enabler of sustainable urban mobility, with Copenhagen's Finger Plan being a global pioneer. Stockholm's current Walkable City Plan and Oslo's new car-free city centre are also guiding examples. The green building sector is also prevalent. This is not surprising given the energy-saving potential associated with northern climates and the presence in the region of world-leading green construction companies, such as Skanska and PEAB.

The Nordic Region has clearly developed a position of global strength in implementing lowcarbon city principles. Nordic cleantech firms that have honed their trade in the Nordic context are now leading companies supporting the transition to low-carbon cities. This includes not only product offerings such as ENVAC (waste management), but also knowledge, design and planning intelligence from companies like WSP Group and Sweco (consulting). Such companies have been strengthened by international knowledge, marketing and communication networks, such as EnviroSweden 9 and Cleantech Finland ${ }^{10}$, to help ensure that their technologies are being effectively exported to the international community.

\subsection{The Circular Economy City Turning waste into resources}

By creating timeless built environments, our cities will continue to be attractive, functional and interesting in the future. Waste can have positive value through creative solutions for reuse, recycling and repair. Buildings are seen not only as shelters, but also as future material banks for new houses, and through industrial symbiosis, waste material from one kind of production can be used as a valuable resource for another kind of production.

A circular economy (CE) refers to a production and consumption system that has as little economic loss as possible and in which most of the

\footnotetext{
9 EnviroSweden, a Web-portal for 591 Swedish companies with the common objective of showcasing Swedish environmental technology to the world.

10 Cleantech Finland is a hub of Finnish cleantech expertise and sustainable innovations in fields such as green building and smart grid energy solutions for cities.
} 


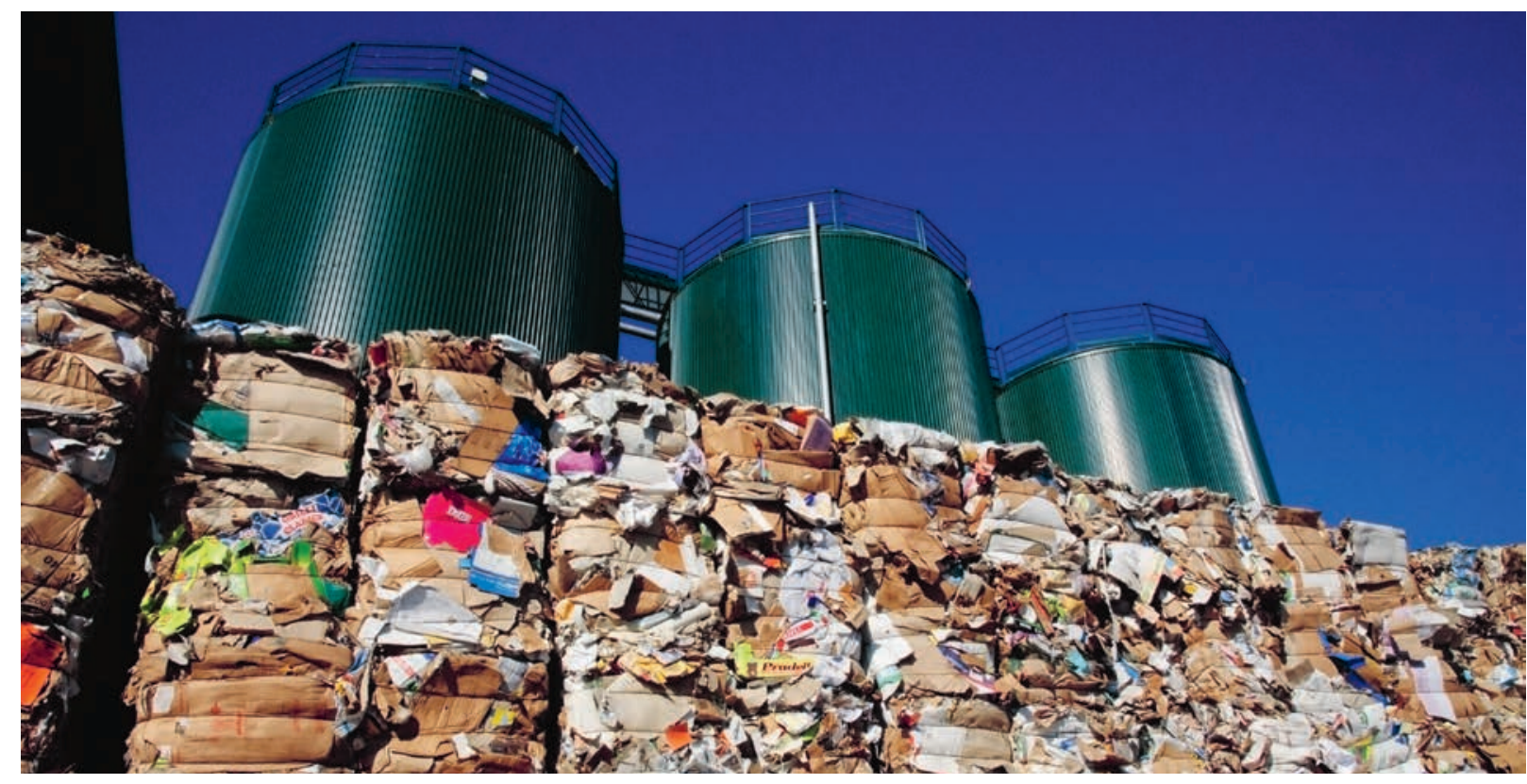

Four Nordic bio-economy strongholds. Source: Norden.org

products and resources used in production can be reused or recycled. This changing design of products and production processes can help minimize waste and increase the potential of unused resources, thereby having a positive environmental impact.

Apart from the business case for enhanced resource efficiency, the environmental and social benefits of switching from a linear to a CE should not be underestimated. The benefits of a CE range from reducing greenhouse gas emissions and encouraging innovation-rich urban environments to creating new workplaces in the areas of reuse, remanufacturing, and materials innovation and changes in consumer behaviour and lifestyles that lead to better health and increased safety (EMF, 2017; URBACT, 2016).

Cities play an important role in driving the transition to CEs, as they have significant waste streams and by-products that can be upcycled, reused or recycled. Building a city-wide CE calls for an inclusive approach that goes beyond the framework of a single company (City of Paris, 2015). A CE implies not only full systemic changes and technological innovations, but also changes in organization, society, financing methods and policies.

\section{No actor can address it alone - collaboration is the key}

The transition to a CE in Nordic cities encompasses both bottom-up and top-down interventions by: (i) the business sector; (ii) public authorities; and (iii), citizens' and communities' activities for urban sustainability.

(i) With respect to the role of businesses, Nordic circular economic initiatives are widespread in sectors such as food, textiles, electric and electronic equipment, building and construction, furniture, and packaging (NCM, 2015). Designing out waste is one of the key principles of CE thinking, and it is applied in the field of product design. For example, the sustainable construction company Xella Danmark produces innovative concrete blocks that can be reused and recycled in all parts of the product life cycle. Nordic CE businesses are also found in the fields of reuse, repair and recycling. The Finnish company Martela designs circular furniture solutions. Their business model ensures the repair of old items and the reuse and recycling of materials; it also promotes modernization and maintenance to the fullest extent (NCM, 2015). Several repair cafés have been opened in Nordic cities to encourage repair and sustainable consumption. Moreover, service- and function-based businesses have gained in popularity in Nordic CE cities (see below).

(ii) Urban authorities (planners and policymakers) in Nordic cities have extensive experience providing sustainable urban infrastructure and management services and in developing innovative policies to support CEs. Providing sustainable waste management and wastewater treatment as services of general interest are two examples. Household waste is turned into energy, and sludge from sewage treatment plants is used for bi- 
G6 Nordic countries have the ability to find and establish synergies between different parties. For instance, from waste you generate electricity and district heating.

JONAS TÖRNBLOM, DIRECTOR MARKETING AND COMMUNICATION AT ENVAC GROUP AB

ogas production, which can then be used in public transport. In Stockholm, park and garden waste is used to produce biochar (soil conditioner) and renewable energy, and Copenhagen has recently announced its commitment to produce plastic packaging from its waste streams by improving the capture of plastics (Resource, 2016; Stockholm Vatten och Avfall, 2017).

A CE is also promoted by innovative policy measures, such as deposit refund schemes for beverage containers, ambitious fossil fuel substitution targets and the use of tools such as public procurement. In 2016, Sweden reduced taxation on the repair of clothes, bicycles, refrigerators and washing machines, thereby stimulating repair services and combating the "throwaway consumer culture" (The Guardian, 2016).

(iii) Bottom-up actions by citizens' networks and groups, and the involvement of businesses in the creation of innovative solutions for sustainable urban environment, play central roles in accelerating the transition to circular cities. Examples include community-driven energy programs, local food initiatives, participation in the sharing economy and so-called collaborative consumption. The sharing economy and collaborative consumption are based on principles of individuals sharing access to products and services instead of maintaining private ownership (Schor, 2016). By shifting the focus from ownership to leasing, the sharing economy changes consumption patterns and contributes to the reduction of structural waste.

In response to the growing popularity of the sharing economy, new business models focused on service and function have sprung up in recent years in Nordic cities. There are three types of service-based business models. The first type includes product and service systems, which refers to sharing or renting a product or service, such as cars, bikes, clothes and tools. For example, the Swedish retail company Houdini offers sports equipment for rent, not for sale. The second type of service- based business model relies on redistribution channels to transfer the ownership of a product from one person to another, often through digital platforms such as Blocket and eBay.

Finally, the third service-based business model concerns collaborative lifestyles, which refers to people sharing non-products, such as knowledge, space and capital, through collective workplaces. Function-based business models in a sharing economy try to create the highest possible use value for the longest possible time while consuming fewer material resources and less energy. This shift advocates the development of more durable products and the extended service life of goods (e.g. repair and reuse networks) (Stahel, 2010). The Vigga retail company in Denmark produces high-quality baby clothes designed to be functional and long-lasting. They even created a subscription service to prolong the life of baby clothes.

\section{Future opportunities for the CE in Nordic cities} According an Ellen MacArthur Foundation study (EMF, 2015), the reduction of avoidable food waste in Denmark is estimated to generate a net value of EUR 150-250 million by 2035. Significant opportunities are also available in the construction and real estate sectors. For example, the sharing and multi-purposing of buildings could create value of EUR 300-450 million by 2035 in Denmark. In addition to the economic gains, moving toward a circular/performance-based economy has positive net effects on employment in cities because service sector businesses (e.g. repair, maintenance, upgrading and remanufacturing) are more labourintensive than mining and manufacturing activities (Wijkman and Skånberg, 2016).

\section{International Outlook}

The CE is rather well-researched across different sectors, particularly mobility, waste management, food and the built environment (e.g. EMF et al., 2015; Geng et al., 2009). However, there is a lack of attention to CE cities in the literature (Prendeville et al., 2017), a lack of research into how the concept can be implemented in cities and what a fully "circular" city entails, and a lack of knowledge about whether CE is being implemented strategically in cities (Lindner et al., 2017; Prendeville et al., 2017). Nevertheless, some research on CE cities has been conducted, mainly by Chinese researchers, with a focus on industrial eco-parks (Prendeville et al., 2017). 
In a recently published paper titled, "Cities in the Circular Economy: An Initial Exploration", the Ellen MacArthur Foundation (2017:12) states that "the research on the 'circular city' has just begun". Another example of increasing interest in this area is the newly launched Horizon 2020 project FORCE, which stands for "Cities Collaborating for Circular Economy", and involves the cities of Copenhagen, Hamburg, Lisbon and Genoa working towards a CE (CE FORCE, 2016).

CE cities appeared on the EU agenda in 2016 with the launching of the Partnership on CE as one of the themes of the Urban Agenda for the EU. The objective of the partnership was to identify innovative and feasible solutions in the field of waste management, sharing economies and resource efficiency in cities (EC, 2016). Several cities have taken a strategic approach to a CE. For instance, London's Waste and Recycling Board has developed London's Circular Economy Route Map (LWARB, 2015), and the French environmental agency $A D E M E$ has produced a white paper on the CE of greater Paris (ADEME, 2016).

In Europe, Amsterdam is referred to as a circular hotspot, and a CE is written into the city's sustainability agenda (Prendeville et al., 2017). Amsterdam set up an innovation program on the $\mathrm{CE}$ and is planning to redesign 20 product or material chains in the city (ASM 2017). Among other prominent European cities that have large commitments to developing a CE include Rotterdam, where a CE is seen as a tool to create sustainable and innovative businesses, and Glasgow, which is completing the Circle City Scan, an extensive research project on urban material flows and the potential of the CE (Prendeville et al., 2017).

Launching the EMF Circular Cities Network in 2016 was an important milestone in advancing the circular city concept. Of the 12 "pioneering circular cities", four are European (Copenhagen, London, Ljubljana, Peterborough) and six are North American (Austin, Boulder, New York, Phoenix, Vancouver, Toronto). The remaining two cities are Rio de Janeiro and Tel Aviv (EMF, 2016). Outside the EU, Vancouver has attracted attention for its CE efforts, as the CE is seen as a solution to the growing problem of waste (VEC, 2016).

As a member of the EMF Circular Cities Network and a partner in the FORCE project, Copenhagen is the forerunner in the Nordic Region in incorporating a CE into its urban operations. In 2016, Copenhagen was internationally acknowl- edged for its Climate Resilient Neighborhood project (ICLEI, 2016). Moreover, the city is developing a decision tool for circular economic public purchasing and procurement (Greater Copenhagen, 2017). Other good practice examples include the Producer Partnership in Oslo, which is an innovative collaboration between Oslo and a plastics manufacturer, and the municipality-run internal furniture circulation platform and Alelyckan Recycling Park in Gothenburg (Lindner et al., 2017). Helsinki (Sitra 2017) and Tampere (Guangzhou Award 2017) have also been acknowledged for their CE practices.

Nordic cities are at the forefront of adopting CE solutions, but they could benefit from a systemic and strategic implementation of a CE in cities, and from research on circular cities that would promote understanding of the concept and facilitate its implementation in practice.

\subsection{The Smart City Implementing intelligent technologies}

The Nordic countries are the most digitalized countries in Europe. Particularly in Sweden and Finland, historically strong development in the mobile telephony sector has created a strong international position in the field of smart cities. Solutions include smart transportation, energy systems (smart grids) and waste and water management. Nordic cities use smart solutions to empower its residents by providing information and education that enable them to use smart technologies.

The digital and smart city approaches play a key role in implementing sustainable urban development. The digital city mainly contributes to this process by integrating new technological features and infrastructure into urban strategies. The smart city approach concerns the management and governance of innovative technologies for better urban environments, including transport and communication infrastructures, energy savings, the maintenance of urban green areas, the reduction of air pollution and sustainable growth, with the goal of improving citizens' quality of life (D'Auria et al., 2014). Digital city solutions are expected to not only improve the efficiency of urban systems and better the environment, but also, with smart management and support from open data, enable a new era for citizen engagement and government transparency. Digitalization also has the potential to improve co-operation in government networks and multi-stakeholder partnerships, as 


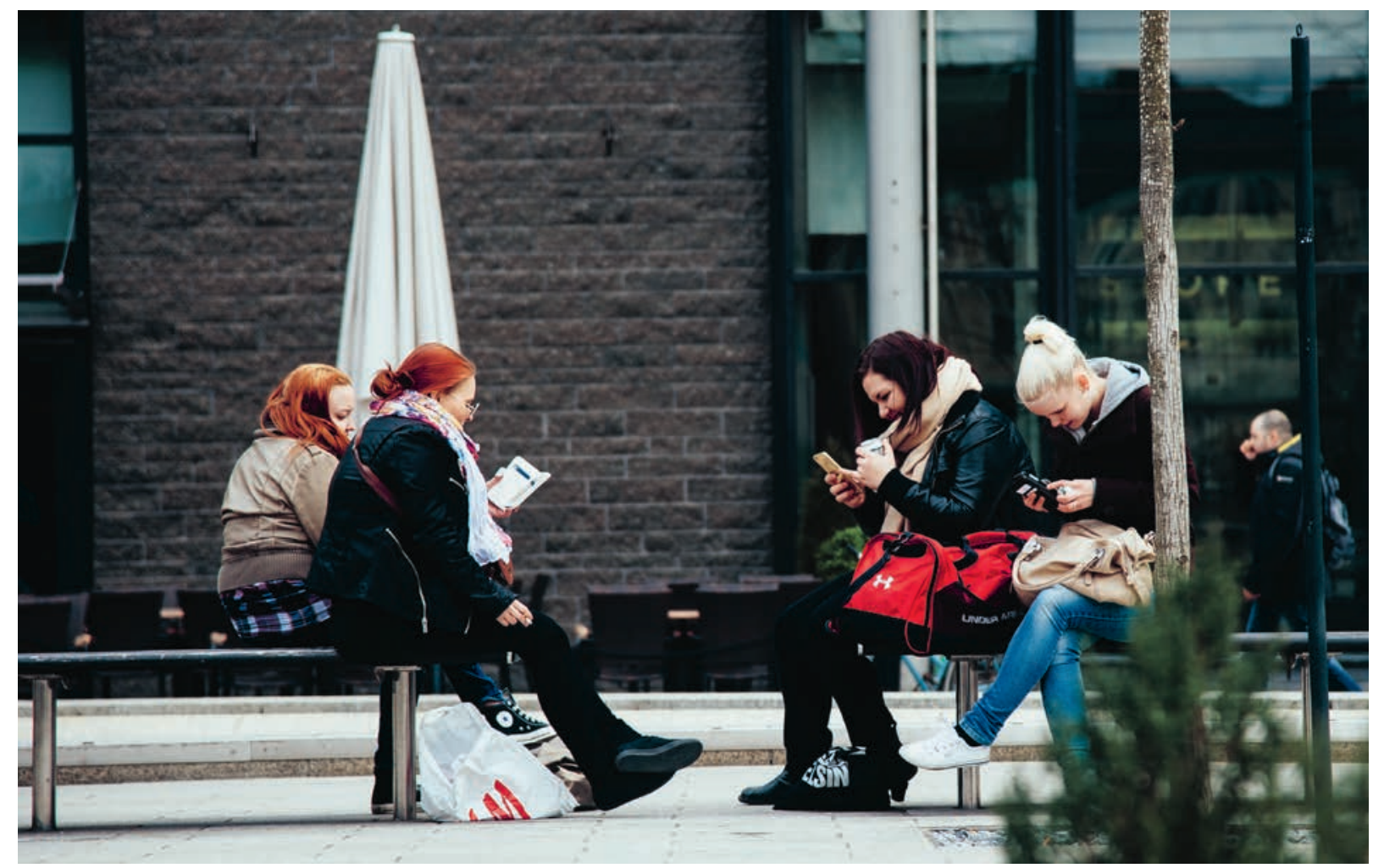

Young women with mobile phones. Source: Benjamin Suomela / Norden.org

well as to enable the integration of different urban functions (energy, buildings, infrastructure, transport and provision of services), thereby improving the efficiency of these functions (Demos Helsinki, 2016). Examples of key ingredients in the Nordic digital city are smart grid solutions for more efficient energy systems, digital tools for citizens' development and improved government systems, intelligent public transport systems to reduce carbon emissions, and public support for open data solutions to improve quality of life.

According to the European Commission's in$\operatorname{dex}\left(\mathrm{DESI}{ }^{11}\right)$ the Nordic countries are the most digitalized in Europe. The commission attributes this performance to the following five key aspects: a well-established broadband infrastructure; strong digital skills in human capital; a high degree of internet usage; the integration of digital technologies in businesses; and the digitalization of public services (European Commission, 2017). These general aspects have also enabled Nordic cities to be forerunners in various smart technology solutions, including the management of urban systems and environments. Nordic cities have been early adop-

11 The Digital Economy and Society Index (DESI) is a composite index that summarizes Europe's digital performance and competitiveness by measuring relevant societal and economic indicators. ters of sound information and communication technology (ICT) infrastructures in cities, and of knowledge expansion through the implementation of smart city solutions. This builds on a long tradition of developing infrastructure to support the digitalization of public services in the public sector. For example, Finland was the first country

\section{Utilizing the Nordic compe- tences in the gaming industry for the digitalisation of planning, e.g., in making 3D models and game-like participation methods.}

KARI TUUKKANEN, BUSINESS AREA DIRECTOR, SITO DIGITAL SERVICES, HELSINKI

to declare that broadband access is a legal right for every citizen, and Sweden ranks fourth in the world in the percentage of fixed broadband subscriptions on fibre-optic networks. The Swedish government is also committed to providing expanded high-speed internet to rural areas, and Stockholm will be the first city in the world with a $5 G$ network in 2018.

However, there are challenges associated with digitalizing cities and implementing smart city solutions on a global scale; collectively, this is known 
as the digital divide. A large percentage of citizens in urban areas do not have the infrastructure and competencies for full participation in a digital urban life. This includes limited access to communication technologies, including broadband connectivity (Ragnedda \& Muschert, 2013). However, the challenges of digitalization are not strictly related to technological issues. There are also challenges associated with changing behaviour and improving knowledge about how to develop and use digital urban services.

\section{Innovation leaders in Smart Grid Development}

Smart grid solutions offer the possibility of transferring electricity from many different power suppliers to consumers using state-of-the-art technologies and intelligent monitoring systems that keep track of all electricity flowing in the system. Smart grids guarantee interoperability at all times of the day, thereby enabling the flexible use of different renewable energy resources. There are many innovative development projects in the Nordic Region that are centred on smart grid development, including an interesting Finnish project involving Empower IM, Elenia, There Corporation, Helen Oy, Fortum, Lappeenranta and Tampere Universities of Technology, and VTT Technical Research Centre of Finland. These partners are developing a system that will enable energy consumption to follow market signals and be able to maximize the benefits of renewable energy generation by controlling and adjusting consumption to time-of-day fluctuations in renewable energy production, such as wind and sun. Thus, it will allow for the full use of solar and wind potentials at all times of the day (TEKES 2016).

\section{Exploiting open data through strong partner- ship between public and private sector}

Digital tools for citizens' engagement is also an area in which Nordic countries have developed excellent knowledge and competence. One promising case is the so-called "block by block" project, which was initiated by Mojang (the makers of Minecraft), UN-Habitat and Swedish Building Services (Svensk Byggtjänst). These actors have been collaborating on an innovative programme in which $\mathrm{Mi}-$ necraft is used as a community participation tool for the design of urban public spaces. The concept focuses on gathering ideas from residents to improve their neighbourhoods. Within My Blocks, residents are encouraged to share their thoughts and ideas in a fun way to influence how their local surroundings will look in the future (Svensk byggtjänst, 2016). This concept has been used in multiple urban planning projects in Sweden, including the relocation of the mining city Kiruna in northern Sweden. The Kiruna project solicited input from 50 schools around Sweden that used Minecraft to contribute urban proposals for new city centre development in Kiruna.

Nordic cities have extensive experience in developing high-quality public transport systems with intelligent digital features. This enhances the efficiency of public transport in terms of both service provision and user experiences. The Finnish company PayiQ is a leading Nordic example of smartphone payment solutions, and it has developed the world's first cloud-based mobile ticketing solution for public and private urban mobility services. The focus is on mobile tickets, security and safety for all means of travel, including various services to support a shared economy. PayiQ is also a Microsoft CityNext Partner and an active member in the Global MaaS Alliance (TEKES, 2015). This project underscores the strengths of the Nordic cities in developing new solutions through strong partnerships between the public and private sectors.

\section{Digital tools for implementing the smart city}

Open data is a key component for implementing a digital city, but the challenge is to use the available data in innovative and productive ways. The added value of open data cannot be realized unless the data are applied in practical and marketable solutions in both the public and private sectors. However, Nordic cities also have a strong tradition of collaboration through public-private partnerships. An interesting example of using new digital solutions based on open data is Helsinki Loves Developers (Hel<3Dev). Hel<3Dev is a concept to enhance open dialogue and developer co-operation by providing an open platform and meet-ups for discussion and co-creation. One solution developed with $\mathrm{Hel}<3 \mathrm{Dev}$ is a mobile application (MOOSE) to help exchange students easily find relevant information about housing, studying and events. MOOSE is based on open data, is freely available to download, and already has one paying customer. Another interesting digital solution developed using Hel<3Dev is the Env\&You project, which has developed a new model for calcu- 
G6 A high level of trust is also an important precondition for open data; trust that the open data will be used for common good. It is easier to build co-operation and to create new innovations when data is open'.

TIINA KÄHÖ, EXECUTIVE DIRECTOR, HELSINKI METROPOLITAN SMART \& CLEAN FOUNDATION

lating more accurate air quality forecasts for the benefit of both citizens and city authorities. The Env\&You project shows how digital solutions can benefit sustainable urban development by mapping out pollution on individual, local and daily levels. It gathers accurate information about the environment to support the well-being of the city's citizens (Helsinki Loves Developers).

A key strength of Nordic cities is the well-developed ICT infrastructure throughout the region. This continues to give Nordic cities a head start in digitalization, leading to many promising solutions for smart city implementation. However, to fully exploit the advantages of a digitalized city, more large-scale testing is needed, and the solutions need to become even more user-friendly. Thus, there is a need for increased Nordic support and joint strategies between public and private actors in the Nordic cities for upgrading technologies globally, as well as support for the internationalization of Nordic solutions. Furthermore, the users of these solutions need to be educated, informed and transformed into "digital citizens" in order for the solutions to be mainstreamed. Therefore, tools, campaigns and other methods of changing user behaviour is a key aspect to be developed in the future.

\section{International outlook}

The research on smart cities is dominated by researchers from Asia, mostly from China, Japan and Taiwan. According to a 2014 literature review, $49 \%$ of papers were from Asia, with Europe as the second most productive continent, with $36 \%$ of the papers. North America had 9\% of the papers, and the remaining continents of Oceania, Africa and Middle/South America had 3\%, 2\% and 1\%, respectively (Cocchia, 2014; D'Auria et al., 2014).

One interesting aspect of the Smart City concept is that use of the smart city in research can be traced back to its origin, around 1994. However, during the 1990s and 2000s, there were very few papers on all continents on the topic until 2010, when the EU relaunched the term in the EU2O2O strategy to boost urban sustainability projects throughout the union. Since then, the number of reviewed papers and urban policies focusing on the smart city has increased tremendously (D'Auria et al., 2014). Outside of the EU, the trend is similar, with an increased focus on developing cities based on the smart city concept. In recent years, largescale city development projects have increased along with increasing urbanization, and the smart city concept has been a key strategy for cities. In particular, megacities in Asia provide some interesting examples, including China's launch of a national smart city strategy for all city regions. Other Asian examples include projects that are using the smart city approach, such as Smart Hong Kong, Shanghai Municipality for Building Smart City and the Taipei Smart City Project Management Office. A similar example in the Middle East is the massive new city development being done for the Sustainable Masdar Smart City (UAE) project. There has also been an increased use of the smart city concept on the North American continent in both Canadian and American cities. A few examples of cities with ambitions to be smart include Smart City New York, Seattle City Initiative, Edmonton Smart City and Montreal Smart City. Additionally, there are some examples in Australia, Latin America and South America, such as City Smart Brisbane and Smart City Panama.

The primary European research cluster seems to be concentrated in the North Sea region, including the Netherlands, Belgium, the UK and the Nordic countries, with a second cluster in the Mediterranean region, including Spain, France and Italy (Cocchia, 2014; D'Auria et al., 2014). In the European arena, Amsterdam is one of the forerunners in digital solutions with the Smart City Amsterdam initiative. This last example emphasizes the efforts to develop a smart city that focuses on living, working, mobility, public facilities and open data through the engagement of innovative businesses, authorities, research institutions and people of Amsterdam.

According to Cocchia (2014) and D'Auria et al. (2014), the research on smart cities in the Nordic countries has made an important contribution to the field, but it is not prominent. However, in recent years the research projects and funding available for smart city projects has increased in the Nordic 
countries, especially considering that the Nordic countries are among the most digitalized countries on the globe. Research on the smart city has been prioritized, as the concept has broad political support in all of the Nordic countries. The larger city regions in the Nordic countries all have welldeveloped smart city strategies and advanced technological solutions for urban planning. One of the more well-known smart city initiatives in the Nordic countries is in Helsinki, which has been a forerunner in this area. The Helsinki Smart City initiative has developed into a strong innovation cluster supported by local and regional authorities. This includes various living lab and mobile application clusters on urban issues, as well as larger flagships projects, such as the Smart Kalasatama district and the co-creation platform called Helsinki Loves Developers. Helsinki also co-organizes hackathon programming marathons and open data apps competitions.

With a history as early adopters of digital urban solutions, a long tradition of creative urban planning and major contributions to Smart Cities research, the Nordic countries are in a strong position internationally in terms of both practice and research.

\subsection{The Design City \\ Placing people and nature in the centre}

It is clear that both urban and interior or product design create a material basis for social life in cities. The physical environment and its design reflect the strong values and developmental paths of the city at the time of their realization. Urban and interior and product design played an important role in branding the Nordic countries and building the Nordic national identities, especially in the decades after the Second World War.

\section{Closeness to nature}

Generalization is necessary to see the values that form the basis for Nordic cities, but there are some specific Nordic urban design traits. First, the dominant natural resources and the dominant industries have shaped the development of Nordic cities. For example, in Norway, the oil, the water and the fisheries have influenced the location of settlements, economic development and energy systems. In Sweden, the historically strong automobile industry has been an influential lobbyist for the importance of transportation planning and car use, whereas the forestry industry has been important for the use of wood as a building material, which has influenced the physical design of Swedish cities and towns.

Second, Nordic urban design should be understood in the context of comparatively late urbanization and small cities. The international style and its ideas of building minimalist functional homes and urban environments, as well as the ideas of preserving nature and safeguarding light and heat in the home in a relatively cold and dark climate, were influential (Arkitekturmuseet, 1980; Saarikangas, 2002). During the post-war era, the cities expanded in terms of both population and the built environment, and the design and plan-

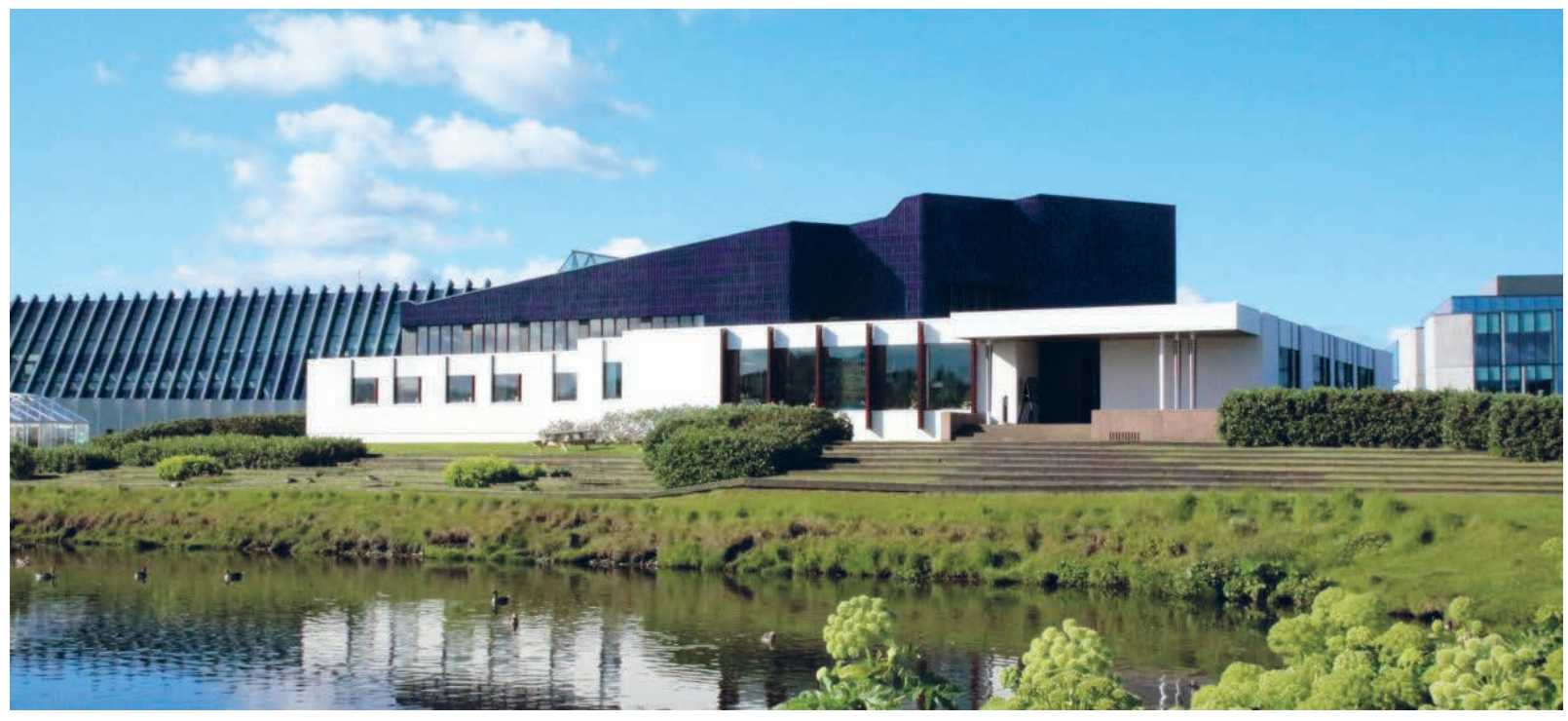

Nordic House, Reykjavík. Source: http://nordichouse.is/en/event/umhverfismatsdagurinn-2017/ 
G6 When we build, we make use of the light, bringing daylight into the building. We understand the value of it, as we spend so much time in buildings in the Nordic Region due to the cold climate.

TINA SAABY, CHIEF CITY ARCHITECT

AT COPENHAGEN MUNICIPALITY

ning ideals of the 1940s-1960s continue to shape the outline of many Nordic cities. This was also an era of fame for Nordic architecture and urban planning, with designers such as Alvar Aalto and Eero Saarinen from Finland and Jörn Utzon from Denmark receiving international attention, along with international visits to the Stockholm suburban development in Vällingby. Suburbanization during the post-war decades can be characterized as neighbourhood-oriented and rather small scale (Engfors, 1987); however, it became bigger during the 1960s and 70s. In some respects, this development reflects the values of the Nordic welfare state, such as equality, closeness to nature, collectivism and community, including emphases on collective spaces, public transportation and local services, making a well-functioning everyday life possible (Saarikangas, 2002). In the contemporary era, the international reputation of Nordic architecture is represented by the Norweigan office Snøhetta or the Danish Bjarke Ingels Group, among others.

\section{Nordic design equals quality}

If urban design during the decades after the Second World War focused on growth through expansion and building on previously undeveloped land, the contemporary post-industrial Nordic vision is to densify these sparse structures and regenerate old industrial land close to city centres. The goal is to decrease the dependency on cars and the need for transportation by creating more compact cities. However, even though there is a strong interest in and focus on the compact city, there remains a strong desire to live just outside the city centre, with easy access to green spaces and public transport, and some (today, often limited) services nearby.

If Nordic urban design is primarily known for post-war examples of high-quality, functionalist, close-to-nature suburban developments, Nordic or Scandinavian product design (the terms Nordic and Scandinavian are often used interchangeably to refer to the same geographic region, although formally, they do not) of furniture and homewares, for example, is internationally famous as representing good quality, good craftsmanship and good use of local materials such as wood and metal (Skou \& Munch, 2016). This is a result of both a few strong individuals networking and succeeding internationally during the decades after the Second World War and the work of craft and design organizations such as Svensk Form, Norsk Form, the Danish guilds, etc., over more than a century. They created arenas for education and debate and brought Nordic design out into the world. The success is also related to the scaling-up of small craft-based businesses, as well as the persistence

C6 Danish architects are respected (...) We have a strong selling point here when it comes to education for landscape architects who focus on sustainability.

TINA SAABY, CHIEF CITY ARCHITECT AT COPENHAGEN MUNICIPALITY

of the natural material tradition that originated in the local production (as in regional, national, Scandinavian, Nordic or Baltic) of design products. Today, the design sector in the Nordic countries is an important growth industry, but it remains small and dominated by small firms, usually one-person companies (Power, 2005; Power et al., 2006); of course, there are larger brands, such as the Finnish littala and Marimekko, and internationally famous products, such as Poul Henningsens PH lamps or Arne Jacobsen's chair Myren (The Ant).

There are those who see the dominant "Scandinavian design" narrative about quality, craftsmanship and "blonde" materials as limiting and apolitical. They prefer alternative stories of more explicit political activism in the field of design, or of the "nonbranding" of products (Fallan, 2012). Nevertheless, these alternative narratives still assume that there is something that can be conceptualized as Scandinavian design.

\section{The importance of norms}

As in urban development, there has been a focus in the design sector on functional everyday life products that are accessible to broad groups of people. 


\section{Nordic architecture is low key, clean and modest}

MADELEINE NOBS, BUSINESS DEVELOPER SUSTAINABLE BUSINESS AT NCC BUILDING \& CONSTRUCTION COMPANY

The idea of the "good home" paired with developments in the construction and furniture industries during the 1900s, as well as the standardization efforts in the 1940s by organizations such as Hemmens Forskningsinstitut (a Swedish institute that researched rational home design), connects urban design and the design of objects in the Nordic context. The home is an expression of identity, and it is supposed to be safe, well-designed and filled with objects that have certain meanings, such as memories and symbols of status or function. The standardization of interior design elements such as kitchen cabinets makes the Nordic home relatively easy to refurnish and renovate, but it has also established a quite strict and normative framework for everyday life. With respect to inclusiveness and "design for all", it should be mentioned that presently, there is a Nordic declaration of universal design (Björk, 2014), and in Sweden, there has been an emphasis on "design for all" since the 1990s (www.designforalla.se).

Even though both urban and interior design during the post-war decades were normative in the sense that they were oriented toward the heterosexual nuclear family and the housewife, this norm did acknowledge the housewife's (unpaid) work. She was the user of practical and hygienic homewares, of hot water and laundry machines; she was the one taking her children to the neighbourhood playground or the local shopping centre. The Swedish interior decorator Lena Larsson revolutionized home life and interior design in the 1950 s by introducing the idea of the family room to replace the formal salon, again with the focus on the rational and practical everyday life of the family. Of course, this is an historical heritage, but it continues to influence Scandinavian and Nordic design practice and marketing to this day.

\section{International outlook}

As is the case with urban and regional planning research, it is possible to distinguish between research for (urban) design and research about (urban) design-that is, there is applied research that tries to change practice, and theoretical research that has design practice as its object of study. In the field of design research, we need to add the experimental approach of "research through design", which uses design as a method rather than analysing its result, i.e. a kind of action research (Laurel, 2003).

Research for urban design that formulates advice and principles for practice has a long history and is perhaps the core of urban design research (see, e.g. Larice and Macdonald, 2013). Danish architect Jan Gehl has influenced the field by focusing on the spaces between the buildings and their impact on social life. Bill Hillier's space syntax theory is also often used to analyse degrees of publicness and accessibility of streets and public spaces, which are measured in flows of people and movement patterns. Other current arenas in which research and practice meet are in the American New Urbanism movement (Congress for the New Urbanism, 1996) and in Landscape urbanism (Waldheim, 2006). Research on urban design often comes from the social sciences and deals with the intersection of the social and the material in such areas as the use of public space (Mitchell, 2003), gentrification (Zukin, 2010) and issues related to disabilities and accessibility (Boys, 2014). So-called tactical urbanism is a recent example of research through design, in that it uses actual interventions in the urban space as a means of experimentation (Lydon and Garcia, 2015). Doing research through design can also involve designing objects that make social norms visible or encourage certain types of social interactions (Ehrnberger, 2017; Grillner, 2013), or it may focus on using "design thinking" in developing a project (Curedale, 2016).

In very general terms, contemporary urban design practice in Europe can be said to have similar ambitions as design practice in the Nordic Region: densification, adoption of new environmental technology and a focus on public transportation. The development of the polders in Amsterdam and the Rieselfeld and Vauban neighbourhoods in Freiburg, Germany are often cited as good European examples. Regarding the design of objects, sustainability concerns started to be incorporated in the 1960s, after Rachel Carson's book Silent Spring was published (Houze, 2010). Today recycling, reuse and sustainable production and consumption are central to the industry, despite the parallel mass consumption of clothing, furniture, housewares, etc. "Scandinavian design" is a wellknown phenomenon outside the Nordic countries and "[d]esign has long been an integral part of 
cultural life in the Nordic countries" (Power et al 2006). The UK Design Council commissioned a report in 2009 comparing a number of countries with respect to "design capabilities", and the Nordic countries rank rather well overall, although there is room for improvement, such as in the education of designers (Moultrie and Livesey, 2009). Among the indicators of Nordic success are public investment levels, trademark registrations, design firms and design graduates. This means that design is measured as a business sector and thus important for national competitiveness. 


\section{THE NORDIC SUSTAINABLE CITY Core narrative}

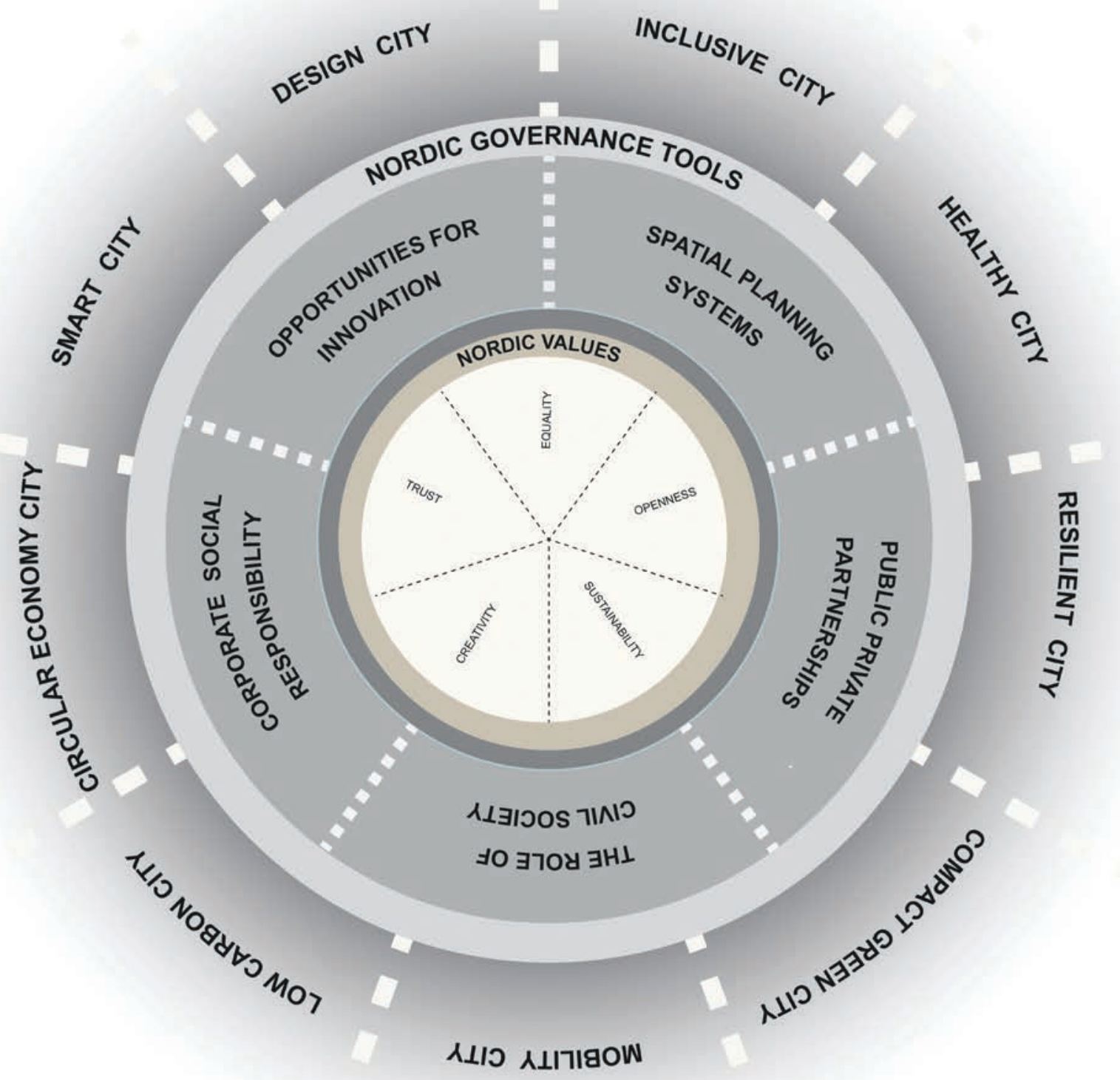

Figure 4: Nordic Sustainable City - framework 


\subsection{Final considerations}

To create a common platform where the competences of various sectors and actors in the Nordic Region are acknowledged, this white paper proposes a framework in which stories of the Nordic Sustainable Cities can be told.

A combination of Nordic values and Nordic tools has resulted in Nordic practices that deliver sustainable urban solutions in different fields. The test of this framework in workshops suggested that this story can function as a platform that, in addition to describing the overall scope of Nordic solutions for sustainable cities, also allows an exploration of multiple paths by which sustainable urban development may be realized.

In these workshops, diverse actors engaged in discussions and developed ideas about the feasibility of implementing solutions in various contexts. While some participants highlighted the value of the story as a checklist of competences in relation to urban sustainable initiatives or projects, others discussed the opportunity for joint action and the opportunity to deliver further sustainable solutions. The simplification needed to maintain a core narrative was also often discussed. This prompted debate on the specific challenges that many cities in the Nordic Region face (such as segregation and housing shortages).

In regard to the Figure 4, it is worth noting that although it represents practices (inclusive, healthy, smart, etc.) as pieces that seem to be contained within boundaries, it is acknowledged that there is a clear interaction between them. For example, the 'circular economy city' certainly has synergies with the 'smart city', considering that digital platforms provide a means of mediating collaborative consumption. Therefore, the story has the ambition to be holistic and dynamic, and one in which the parts (values, tools, practices) can be combined.

\section{Communicating the story of the Nordic Sustainable Cities to other audiences}

The double and conflicting task of telling the same story to different audiences deserves some attention here. In this respect, we emphasize that the actors of the Nordic Region are the exclusive target group of this story. As argued above, the standards achieved by some cities in the Nordic Region are the result of long-standing processes whereby societal values have influenced governance tools and practices. The preconditions for the im- plementation of sustainable measures in the cities of the Nordic Region are thus grounded in historical processes that are unique in the Nordic Region.

Therefore, communicating this story to other audiences outside the Nordic Region requires shifting the perspective from which the story can be told. Rather than departing from the Nordic values, the story should focus on the Nordic practices.

Thus, the core story could have two narratives: one of enhancing cohesion among diverse actors by highlighting the added value of the Nordic countries working together, and the other of communicating good practices and sharing experiences with audiences outside the Nordic Region that could contribute to 'making cities inclusive, safe, resilient and sustainable'. The figures 5 and 6 illustrate both possibilities.

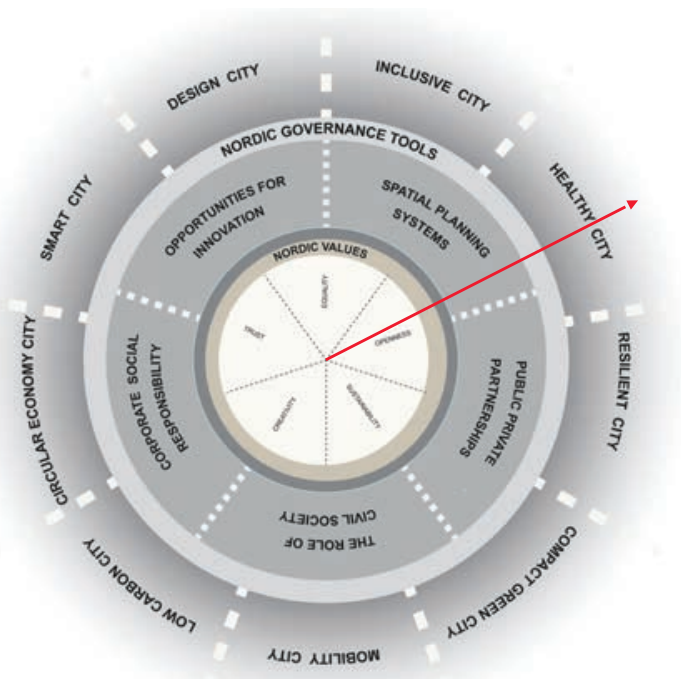

Figure 5: Telling the story to build cohesion among actors in the Nordic Region

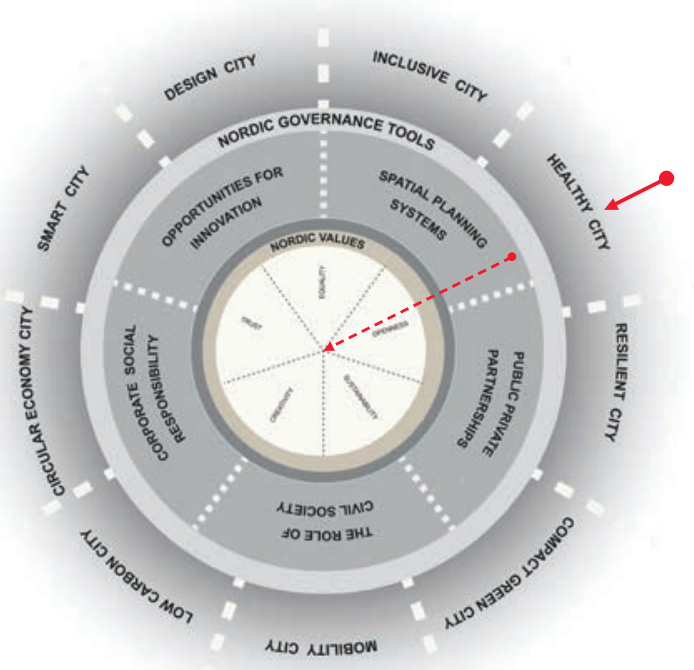

Figure 6: Telling the story to other audiences outside the Nordic Region 
Although they have overcome challenges, Nordic cities will probably face many others in the near future, especially in relation to changing climate and demography. Thus, telling the story of Nordic Sustainable Cities to other audiences seems to be a remarkable opportunity to co-create knowledge about sustainability with and in different socioeconomic and political contexts. Exploring the viability of implementing Nordic solutions in different circumstances will probably require negotiation and adjustments of the 'Nordic way', which should account for other cultures' distinct social prac- tices, institutional settings and informal values. Understanding different urban realities will also inform and help Nordic cities prepare for future uncertainty.

Despite challenges, telling this story outside the Nordic Region may be an enlightening process, in which cities with different preconditions can learn from each other, while attempting to minimize urban environmental and social problems. Such exchanges and knowledge adaptation are fundamental requirements for achieving a more sustainable global urban future. 


\section{References}

\section{Introduction}

Babbie, E. (2010). The practice of social research. Wadsworth: Cengage Learning.

City of Copenhagen (2009): Copenhagen

Climate Plan - The short version. Online, available at: https://www.energycommunity. org/documents/copenhagen.pdf. Retrieved on 15 December 2016

[EU] European Union (2016) Urban agenda for the EU. Pact of Amsterdam. Agreed at the informal meeting of the EU ministers responsible for urban matters, 30 May 2016 in Amsterdam.

Engström, C-J. (2016) Nordic urban ways. Local leadership, governance and management for sustainable development. Stockholm: Global Utmaning.

Kommunal- og regionaldepartementet \& Miljøverndepartementet (2013) Faglig råd for bærekraftig byutvikling. Oslo. Online, available at: https://www.regjeringen.no/globalassets/ upload/MD/2013/Sluttrapport_byradet.pdf. Retrieved on 10 December 2016.

Norden - Nordic Innovation (2012): Nordic Built Chart. Online, available at: http://www. nordicinnovation.org/Documents/Nordic\%20 Built\%2Odocuments/Nordic\%20Built\%20 Charter.pdf. Retrieved on 10 December 2016 Norden - Nordic Innovation (2015): Nordic Urban Strengths and Challenges. Online, available at: http://nordicbuiltcities.org/wp-content/ uploads/2015/04/Nordic-Urban-Strengthsand-Challenges_2015.pdf. Retrieved on 10 December 2016

[NCM] Nordic Council of Ministers (2012). The Nordic Eight:Nordic solutions for sustainable cities. Copenhagen: Nordic Council of Ministers. Online, available at: http://www. stadinilmasto.fi/files/2014/08/Nordic-solutions-for-sustainable-cities.pdf. Retrieved in 15 December 2016

Ramboll (2016): Market Analysis and Action Plan. Report intended to Nordic Innovation.

Smas, L., Oliveira e Costa, S., Fredricsson,C., Feuk, F. (2016). Towards Sustainable Nordic City-Regions A synthesis of the activities of the Nordic Working Group for Green Growth: Sustainable Urban Regions, Nordregio report 2016:2.
Online, available at: http://www.nordregio.se/ Global/NWG\%204/Synthesis\%2Oreport.pdf. Retrieved on 10 December 2016.

[UN] United Nations - Habitat (2016) New urban agenda. Quito declaration on sustainable cities and human settlements for all. Document adopted at United Nations on Housing and Sustainable Urban Development in Quito, October 2016

[UN-DESA] United Nations - Department of Economic and Social Affairs (2015): World Population Prospects: The 2015

Revision, Key Findings and Advance Tables. Working Paper No. ESA/P/WP.241.

[UN] United Nations Human Settlements Programme (2011). Cities and Climate Change Global Report on Human Settlements. Online available at: http://mirror.unhabitat.org/pmss/ listltemDetails.aspx?publicationID=3086. Retrieved 15 April 2017.

[UN] United Nations (2015). Transforming our world: the 2030 Agenda for Sustainable Development. Online available at: http://www. un.org/ga/search/view_doc.asp?symbol=A/ RES/70/1\&Lang=E. Retrieved in 15 December 2016

\section{Nordic values}

Alestalo, M.; Hort, S. E. O. and Kuhnle, S. (2010) The Nordic Model: Conditions, Origins, Outcomes and Lessons. Hertie School of Governance-Working Paper 41. Online, available at: http://edoc.vifapol.de/opus/volltexte/2013/4255/pdf/41.pdf. Retrieved in 15 March 2017

Kokko, A. and Tingvall, P. G. (2007) The Welfare State: Vietnamese development and Swedish experiences. Online, available at: http:// swopec.hhs.se/eijswp/papers/eijswp0235.pdf. Retrieved on 10 January 2015.

Lindbom, A. (2001) Dismantling the Social democratic welfare model? Has the Swedish welfare state lost its defining characteristics? Scandinavian Political Studies, 24 (3), 171-193.

[NCM] Nordic Council of Ministers (2015). Strategy for International Branding of the Nordic Region 2015-2018. Online, available at: 
http://norden.diva-portal.org/smash/get/ diva2:783406/FULLTEXT01.pdf. Retrieved on 18 December 2016

Save the Children (2015). The Urban Disadvantage: State of the Worlds' Mother 2015. Online, available at: http://www.savethechildren. org/atf/cf/\%7B9def2ebe-10ae-432c-9bdOdf91d2eba74a\%7D/SOWM_EXECUTIVE_SUMMARY.PDF. Retrieved on 15 May 2017.

Rothstein, B. and Stolle, D. (2003) Introduction: Social capital in Scandinavia. Scandinavian Political Studies, 26 (1), 1-26.

\section{Nordic tools Introduction}

Bogason, P. (2000) Public Policy and Local Governance: Institutions in Postmodern Society. Cheltenham, Edward Elgar Publishing Limited.

Bucchi, M.; Neresini, F. (2008) "Science and Public Participation" In: Hackett et al. (eds.) The Handbook of Science and Technology Studies. Third Edition. The MIT Press, Cambridge, Massachusetts) pp 449-472

Cass, N. (2006) Participatory-Deliberative Engagement: A literature review. Published by the School of Environment and Development", Manchester University, Manchester M13 9PL, UK. Online, available at: https://core.ac.uk/ download/pdf/16285075.pdf. Retrieved on 10 June 2017

\section{Spatial Planning System in the Nordic Countries}

[EC] European Commission. (1997). The EU

Compendium of Spatial Planning Systems and Policies (Regional Development Studies). Luxemburg: Commission of the European Communities.

Fredricsson, C., \& Smas, L. (2013). En granskning av Norges planeringssystem: Skandinavisk detaljplanering i ett internationellt perspektiv (Nordregio Report No. 2013:1) (p. 81). Stockholm: Nordregio.

Mäntysalo, R., Saglie, I., \& Cars, G. (2011). Between input legitimacy and output efficiency: defensive routines and agonistic reflectivity in Nordic land-use planning. European Planning Studies, 19, 2109-2126.

Røiseland, A., Hofstad, H., Lidström, A., \& Sørensen, E. (2015). Taking Stock of Regional Governance in Nordic Countries. Scandinavian Journal of Public Administration, 19(4), 3-6.
Smas, L., \& Fredricsson, C. (2015, June). Tensions in Nordic urban planning. Nordregio News, (2). Online, available at: http://www.nordregio.se/ Global/Publications/Publications\%202015/ NN\%2Olssue\%2O2\%202015.pdf. Retrieved on 15 April 2017.

\section{Public-Private Partnerships}

Hanssen, G. S. (2012). Negotiating urban space: The challenge of political steering in marketand network-oriented urban planning. Scandinavian Political Studies 35 (1), 22-47.

Mäntysalo, R. and Saglie, I.-L. (2009). Private influence preceding public involvement: strategies for legitimizing preliminary partnership arrangements in urban housing planning in Norway and Finland. Planning Theory and Practice, 11(3), 317-338.

Perjo, L., Fredricsson, C. \& Oliveira e Costa, S. (2016) Public-Private-People partnerships in urban planning. Baltic Urban Lab Working Paper. http://www.nordregio.se/en/Publications/Publications-2016/Public-Private-PeoplePartnership-in-urban-planning/

Schmidt-Thomé, K. (2015). Between fulfilment and vitiation - discerning incapacitation in urban regeneration. Aalto University publication series, Doctoral dissertation 176/2015.

Sharma, K. (2016). Public-private partnerships and 2030 agenda for sustainable development. Blog post. Online, available at: http://blogs. worldbank.org/ppps/public-private-partnerships-and-2030-agenda-sustainable-development. Retrieved on 15 May 2017.

Smas, L., Fredricsson, C., Larsson, V. \& Perjo, L. (2015) Ansträngande partnerskap: Näringslivet i nordisk stadsplanering. Nordregio Working Paper 2015:3. Online, available at: http:// www.nordregio.se/en/Publications/Publications-2016/Anstrangande-partnerskap-naringslivet-i-nordisk-stadsplanering/ Retrieved on 10 April, 2017

\section{The Role of Civil Society}

Brochmann G and Rogstad, J (2004) "På sidelinjen? Vilkår for deltakelse i politikk og organisasjonsliv i Norge", i Justitiedepartementet, Ds 2004:49 Föreningsliv, makt och integration.

Ibsen, B and Habermann, U (2005) "Defining the Nonprofit Sector: Denmark." Working Papers of the Johns Hopkins Comparative Nonprofit Sector Project, No. 44. Baltimore: The Johns 
Hopkins Center for Civil Society Studies. [SOU] Statens Offentliga Utredningar (2016) Palett för ett stärkt civilsamhälle - SOU 2016-

13. Online, available at: http://www.regeringen. se/492b2d/contentassets/907a5e554a2342 8f9aef3c2d7221a2de/palett-for-ett-starktcivilsamhalle-sou-2016_13.pdf. Retrieved on 10 April 2017

\section{Corporate Social Responsibility}

Baver, B., Fischer-Bogason, R., de Boer, L., Kivistö, T. \& Vildåsen, S. (2016), Greening state framework contracts: Approaches in the Nordic countries. Online, available at: https://norden. diva-portal.org/smash/get/diva2:910464/ FULLTEXTO3.pdf. Retrieved on 9 June, 2017

Carson, S. G., Hagen, Ø., \& Sethi, S. P. (2015). From implicit to explicit CSR in a Scandinavian context: The cases of HÅG and Hydro. Journal of Business Ethics, 127(1), 17-31.

Carson, S. G., Fet, A. M., \& Skaar, C. (2011). A Nordic perspective of corporate social responsibility (CSR). Etikk i praksis-Nordic Journal of Applied Ethics, 5(1), 3-8.

[EC] European Commission (2011) A renewed EU strategy 2011-14 for Corporate Social Responsibility. Online available at: http://www. europarl.europa.eu/meetdocs/2009_2014/ documents/com/com_com(2011)0681_/com_ com(2011)0681_en.pdf. Retrieved on 10 May 2017

Gjølberg, M. (2010). Varieties of corporate social responsibility (CSR): CSR meets the "Nordic Model". Regulation \& Governance, 4(2), 203229.

Ihlen, Ø. and Høivik H. von W. (2015) Ye olde CSR: the historic roots of corporate social responsibility in Norway. Journal of Business Ethics, 127(2015)1:109-120. Doi: 10.1007/s10551-0131671-9

[NCM] Nordic Council of Ministers (2012) The Nordic Strategy for Corporate Social Responsibility - Supporting Nordic business for tomorrow. Online, available at: http://norden. diva-portal.org/smash/get/diva2:701351/ FULLTEXT01.pdf. Retrieved on 9 June 2017.

Sjöström, T. and Scott Jakobsson, L. (2016). Agents for change: How public procedures can influence labour conditions in global supply chains. Case studies from Brazil, Pakistan and Thailand. Online, available at: http://www. swedwatch.org/sites/default/files/tmp/82_
agents_for_change_enkelsidor_O.pdf. Retrieved on 9 June 2017

Strand, R. and Freeman, R. E. (2015). Scandinavian cooperative advantage: The theory and practice of stakeholder engagement in Scandinavia. Journal of business ethics, 127(1), 65-85.

Strand, R., Freeman, R. E. \& Hockerts, K. (2015). Corporate social responsibility and sustainability in Scandinavia: an overview. Journal of Business Ethics, 127(1), 1-15.

\section{Innovation}

Edquist, C. (2002) 'Innovationspolitik och innovationssystem'. In: Sturesson, L., Summerton, J., Ellegård, K. and Beckman, S. (eds.) Spänningsfält: tekniken-politiken-framtiden, pp. 243-263. Stockholm: Carlssons.

Etzkowitz, H. and Leydesdorff, L. (eds.) (1997) Universities in the Global Economy: A Triple Helix of University-Industry-Government Relations. London: Cassell Academic.

Fagerberg, J. (2005) 'Innovation. A guide to the literature'. In: Fagerberg, J., Mowery D. C. and Nelson R. R. (eds.) The Oxford Handbook of Innovation, pp. 1-21. Oxford University Press.

Fogelberg, H. and Thorpenberg, S. (2012) 'Regional innovation policy and public-private partnership: The case of Triple Helix Arenas in Western Sweden', Science and Public Policy, 39: 347-56.

Schumpeter, J. A. (1934) The Theory of Economic Development. Oxford: Oxford University Press.

\section{Nordic practices Introduction}

Giffinger, R., Fertner, C., Kramar, H., Kalasek, R., Pichler-Milanoviü , N., \& Meijers, E. (2007). Smart Cities: Ranking of European MediumSized Cities . Vienna, Austria: Centre of Regional Science (SRF), Vienna University of Technology. Online, available at http://www. smart-cities.eu/download/smart_cities_final_ report.pdf . Retrieved on 01 June 2017.

Macia, L. (2015). Using Clustering as a Tool: Mixed Methods in Qualitative Data Analysis. The Qualitative Report, 20(7), 1083-1094. Online, available at: http://nsuworks.nova.edu/tqr/ vol20/iss7/9. Retrieved on 1 June 2017.

Norden - Nordic Innovation (2012): Nordic Built Chart. Online, available at: http://www. nordicinnovation.org/Documents/Nordic\%20 Built\%2Odocuments/Nordic\%20Built\%20 Charter.pdf. Retrieved on 10 December, 2016 
[NCM] Nordic Council of Ministers (2017). Sustainable Development Action-the Nordic Way: Implementation of the Global 2030 Agenda for Sustainable Development in Nordic Cooperation. TemaNord 523. Online, available at: https://norden.diva-portal.org/smash/get/ diva2:1092868/FULLTEXT01.pdf. Retrieved on O1 June 2017.

[NCM] Nordic Council of Ministers (2015). Strategy for International Branding of the Nordic Region 2015-2018. Online, available at: http://norden.diva-portal.org/smash/get/ diva2:783406/FULLTEXT01.pdf. Retrieved on 10 December 2016

\section{The Inclusive City}

Andersen, H. S. (2012). Housing policy in the Nordic countries and its implication for the housing of immigrants. SBi 2012:03. Danish Building Research Institute, Aalborg University.

Björk, E. (2014) A Nordic Charter for Universal Design, Scandinavian Journal of Public Health; 42: 1-6.

Dikeç, M (2007) Badlands of the republic: space, politics, and urban policy, Oxford: Blackwell.

European Commission (2016) The State of European Cities 2016: Cities leading the way to a better future, Luxembourg: Publications Office of the European Union.

Eurostat (2016) Sustainable development in the European Union: A statistical glance from the viewpoint of the UN sustainable development goals, Luxembourg: Publications Office of the European Union.

Fainstein, S (2010) The just city, Ithaca, N.Y.: Cornell University Press.

Florida, R (2017) The new urban crisis: how our cities are increasing inequality, deepening segregation, and failing the middle class - and what we can do about it, New York: Basic Books.

Gaffikin, F and Morrissey, M (2011) Planning in divided cities: collaborative shaping of contested space, Hoboken, N.J: Wiley-Blackwell Pub.

Hajer, M and Reijndorp, A (2001) In search of new public domain: analysis and strategy, Rotterdam: NAi Publishers.

Jacobs, J. (2011/1961) The Death and Life of Great American Cities, New York: Modern Library.

Koonings, K and Kruijt, D (eds) (2009) Megacities: the politics of urban exclusion and violence in the global south, London: Zed Books.

Kugelberg, C. and Trovalla, E. (2015) Samverka och /eller styra. Att praktisera medborgarinflytande i planering och beslutsfattande, Göteborg: Makadam.

Lindholm, T., Oliveira e Costa, S., Wiberg, S. Introduktion (2015) in Lindholm, T., Oliveira e Costa, S., Wiberg, S. (2015) Medborgardialog - demokrati eller dekoration? Tolv röster om dialogens problem och potential i samhällsplaneringen, Arkus.

Listerborn, C. (2015) Medborgarinflytande - om makt, genus och stadsutveckling in Lindholm, T., Oliveira e Costa, S., Wiberg, S. (2015) Medborgardialog - demokrati eller dekoration? Tolv röster om dialogens problem och potential $i$ samhällsplaneringen, Arkus.

[OECD] Organisation for Economic Co-operation and Development (2015) The metropolitan century: understanding urbanisation and its consequences, Paris: OECD Publishing.

[OECD] Organisation for Economic Co-operation and Development (2016) Making cities work for all: data and actions for inclusive growth, Paris: OECD Publishing.

Ortiz-Ospina E. and Roser, M. (2017) - 'Trust', retrieved from: ourworldindata.org/trust

UN Habitat (2015) The City Prosperity Initiative 2015 Global City Report. Online, available at, https://unhabitat.org/urban-initiatives/initiatives-programmes/city-prosperity-initiative/ Retrieved on 15 October 2017

van den Dool, L, Hendriks, F, Gianoli, A, Schaap, L (2015) The quest for good urban governance: theoretical reflections and international practices, Wiesbaden: Springer Vs.

Wanjiku Kihato, C (ed) (2010) Urban diversity: space, culture, and inclusive pluralism in cities worldwide, Washington, D.C.: Woodrow Wilson Center Press.

Wolch, J R, Byrne, J, Newell, J P (2014) Urban green space, public health, and environmental justice: The challenge of making cities 'just green enough', Landscape and Urban Planning 125 (2014) 234-244.

\section{The Healthy City}

Barton, H., Mitcham, C. and Tsourou, C. (eds) (2003): Healthy urban planning in practice: experience of European cities. Report of the World Health Organization WHO City Action Group on Healthy Urban Planning (HUP) 
Carson, R. (2002/1962): Silent Spring. Houghton Mifflin Company: Boston, New York

Copenhagen Climate Plan (2009). Online, available at: https://www.energycommunity.org/ documents/copenhagen.pdf. Retrieved on 15 December, 2016.

[EEA] European Environment Agency (2017) Air quality in Europe - 2017 report. Online, available at: https://www.eea.europa.eu/publications/air-quality-in-europe-2017/at_download/ file. Retrieved on 20 October 2017.

Egerö, U. and Malmros, B. L. (date). Stockholm's Blue-Green Infrastructure. Online, available at: http://www.cardiff.ac.uk/archi/research/ cost8/case/greenblue/sweden-stockholm.pdf. Retrieved on 15 April 2017

Frumkin, H. (2005). Health, Equity and the Built Environment. Guest editorial note. Online, available at: https://www.ncbi.nlm.nih.gov/ pmc/articles/PMC1257564/ Retrieved in April 2017.

Gelormino, E.; Melis, G.; Marietta, C. and Costa, G. (2015): From built environment to health inequalities: An explanatory framework based on evidence. Preventive Medicine Reports 2 737-745

Guzman-Herrador B, Carlander A, Ethelberg $S$, Freiesleben de Blasio B, Kuusi M, Lund V, Löfdahl M, MacDonald E, Nichols G, Schönning C, Sudre B, Trönnberg L, Vold L, Semenza JC, Nygård K. (2015): Waterborne outbreaks in the Nordic countries, 1998 to 2012. Euro Surveill. 20(24):pii=21160. DOI: http://dx.doi. org/10.2807/1560-7917.ES2015.20.24.21160

Hockenos, P. (2017) With Norway in Lead, Europe Set for Surge in Electric Vehicles. In YaleEnvironment360. Online, available at: http://e360. yale.edu/features/with-norway-in-the-leadeurope-set-for-breakout-on-electric-vehicles. Retrieved on 15 May 2017

Invest Health - strategies for healthier cities. Online, available at: https://www.investhealth. org/ Retrieved on September 2017

Jorgensen, J. (2004): Copenhagen - Evolution of the Finger Structure. Chapter 8 in DuboisTaine, G (ed): From Helsinki to Nicosia: eleven cases of Studies and Synthesis. Cost Office: Brussels

Kleiner, S. and Hor, R. (2016): Urban design: an important future force for health and wellbeing. The Lancet, 388(10062): 2848-2850. DOI: http://dx.doi.org/10.1016/S01406736(16)31578-1
Kristjánsdóttir, S. (2008): The contemporary urban fringe of the city of Reykjavík, Iceland, chapter 6 in Qviström, M. 'Nordiska studier av stadsnära landskap'. Fakulteten för landskapsplanering, trädgårds- och jordbruksvetenskap. Sverige Lantbrukuniversitet SLU, Aarnap

Lafond, L. J. and Heritage, Z. (2009): National networks in Cities in Europe. Health promotion International 24 (1) i100:i107. Doi: 10.1093/ heapro/dap060

Lennon, M., Douglas, O. and Scott, M. (2017): Urban green space for health and well-being: developing an 'affordances' framework for planning and design. Journal of Urban Design, 22 (6) 778-795. DOI: https://doi.org/10.1080/13 574809.2017 .1345845

Malmö Stad (2013): Hälsofrämjande stadsplanering. Nationella Healthy Cities Nätverket. Online, available at: http://healthycities.se/wpcontent/uploads/2014/10/Halsoframjande_ stadsplanering.pdf. Retrieved in 22 September 2017

Manningham City (2017) Healthy City Strategy 2017-2021. Online, available at: https://www. manningham.vic.gov.au/file/27246. Retrieved in September 2017.

Marshall, J. D.; Braver, M. and Frank, L. D. (2009): Healthy Neighborhoods: Walkability and Air Pollution. Environmental Health Perspectives: 117 (11) 1752-1759

McGranahan, G. and Satterthwaite, D. (2000): Environmental health or ecological sustainability? Reconciling the brown and green agendas in urban development. Chapter 4 in Pugh, C (ed): Sustainable Cities in Developing Countries. Earthscan, NY

Milan Municipality (2015): Milan urban Food Policy Pact. Online, available at: http://www. milanurbanfoodpolicypact.org/wp-content/ uploads/2016/06/Milan-Urban-Food-PolicyPact-EN.pdf. Retrieved in 22 September 2017.

Nilsson K., Sangster M., Konijnendijk C. (2011) Forests, Trees and Human Health and Well-being: Introduction. In: Nilsson K. et al. (eds) Forests, Trees and Human Health. Springer, Dordrecht

[NILU] Norwegian Institute for Air Research (2016): Annual Report 2015. Online, available at: http://www.nilu.no/Portals/O/Files/ Aarsmagasin\%20og\%2Oberetning/Aarsrapport_2015_Engelsk_web.pdf. Retrieved in 29 May, 2017

Norden (2007) Nordic aspects of air pollution 
and health in Europe (NORDAIR). Online, available at: https://www.norden.org/en/ nordic-council-of-ministers/council-of-ministers/the-nordic-council-of-ministers-for-theenvironment-mr-m/institutes-co-operativebodies-and-working-groups/working-groups/ the-marine-group-hav/nordair. Retrieved 2nd May, 2017.

Rispling, L. Grunfelder, J., Norlén G.; Wang, S., Randall, L., Lindberg, G., Hanell, T., Schürmann, C. and Zaucha, J. (2016) Trends, challenges and potentials in the Baltic Sea Region. Online, available at: https://tillvaxtverket. se/download/18.7c3ce8ba157d264d2e9cbf 7f/1479389789736/Trends,\%2Ochallenges\%20 and\%20potentials\%20in\%2Othe\%2OBaltic\%20Sea\%2ORegion.pdf. Retrieved on 20 October 2017.

State of Green (2017). Rethinking urban Water for new Value in Cities: sustainable solutions for integrated urban water management. Rethinking Water Network, Danish Water Forum and State of Green

Stockholm City Council, (2010) The Walkable City: Stockholm City Plan. Online, available at: http://international.stockholm.se/globalassets/ovriga-bilder-och-filer/the-walkable-city--stockholm-city-plan.pdf. Retrieved on 2nd May 2017.

Söderström, P.; Schulman, H.; Ristimäki, M. (2015): Urban Form in the Helsinki and Stockholm City Regions: Development of Pedestrian, Public Transport and Car Zones. Reports of the Finnish Environment Institute 16. Online available at: https://helda.helsinki.fi/bitstream/ handle/10138/155224/SYKEre_16_2015. pdf?sequence $=4$

Vancouver City (2015). A Healthy City for All Healthy City Strategy - Four year action plan 2015 - 2018 | phase 2. Online, available at: http://vancouver.ca/files/cov/Healthy-CityStrategy-Phase-2-Action-Plan-2015-2018.pdf. Retrieved on 22 September 2017

WHO - World Health Organization (2010). Why urban health matters? Online, available at: http://www.who.int/world-health-day/2010/ media/whd2010background.pdf. Retrieved on 15 April 2017.

World Health Organization - WHO (2015): National healthy cities networks in the WHO European Region. Promoting health and wellbeing throughout Europe. Lafond, L. E. (ed).
Online, available at: http://www.euro.who. int/__data/assets/pdf_file/0011/285995/ Healthy-Cities-promoting-health-and-equity. pdf?ua=1. Retrieved on 22 September 2017.

\section{The Resilient City}

Bhamra, R., Dani, S. and Burnard. K. (2011).

Resilience: the concept, a literature review and future directions, International Journal of Production Research, 49:18, 5375-5393. http:// dx.doi.org/10.1080/00207543.2011.563826

Batty, M. (2008). The size, scale, and shape of cities. Science, 319(584), 769-771

Eraydin, A. Tasan-Kok, T. Eds. (2013). Resilience Thinking in Urban Planning, Springer

Godschalk, D. R. (2003). Urban hazard mitigation: Creating resilient cities. Natural Hazards Review, 4(3), 136-143

Goodsite, M.E., M. Davis, R.J.T. Klein, B. Davídsdóttir, R. Atlason S. Juhola, M. Landaver, B.O. Linnér, T. Neset, E. Glaas, G. Eskeland (2015). White Paper: Climate Change Adaptation in the Nordic Countries. Nordic Climate, Mitigation, Adaptation and Economic Policies Network (N-CMAEP), Norden Top-level Research Initiative, Oslo, Norway. Online, available at: https://www.sei-international.org/mediamanager/documents/Publications/Climate/NCMAEP-2013-White-Paper-Nordic-CountriesAdaptation.pdf. Retrieved on 19 April 2017

[ICLEI] International Council for Local Environmental Initiatives -(2013). Resilient Cities series. Online, available at: http://resilient-cities. iclei.org/resilient-cities-hub-site/about-theglobal-forum/resilient-cities-2013/ Retrieved on 25 September 2017

[IPCC] Intergovernmental Panel on Climate Change Climate Change (2014). Climate Change 2014: Synthesis Report. Summary for Policymakers. Online, available at: http:// www.ipcc.ch/pdf/assessment-report/ar5/syr/ AR5_SYR_FINAL_SPM.pdf. Retrieved on 19 April 2017

Klimakvarter (2016), The Climate Resilient Neighbourhood Østerbro, the showcase for climate change solutions. Online, available at: http://klimakvarter.dk/wp-content/uploads/2015/08/Copenhagens-first-climate-resilient-neighbourhood_WEB_low.pdf. Retrieved on 19 April 2017

Langlais, R. (2009). 'Adaptigation'. Journal of Nordregio, (4). 2. Online, available at: http:// 
www.nordregio.se/en/Metameny/About-Nordregio/Journal-of-Nordregio/2009/Journal-ofNordregio-no-4-2009/Adaptigation/ Retrieved on 19 April.2017

McCormick, K., Anderberg, S., Coenen, L., \& Neij, L. (2013). Advancing Sustainable Urban Transformation. Journal of Cleaner Production, 50, 1-11. DOI: 10.1016/j.jclepro.2013.01.003

Meerow, S. et 2016. Defining urban resilience: A review, Landscape and Urban Planning 147 (2016) 38-49

Mehmood, A. (2016) Of resilient places: planning for urban resilience, European Planning Studies, 24:2, 407-419

Morgen, M. (2009). Nordic Climate Change Research, Nordforsk Policy Briefs 2009-8. Online, available at: https://www.nordforsk.org/no/ publikasjoner/publications_container/policybrief-8-2009-nordic-climate-change-research/ download. Retrieved on 19 April 2017

Norden (2014) Nordic Action on Climate Change, Nordic Council of Ministers Publication. Online, available at: http://norden.diva-portal.org/ smash/get/diva2:768493/FULLTEXT01.pdf. Retrieved on 19 April 2017

Pu, B. and Qiu, Y. (2016). Emerging Trends and New Developments on Urban Resilience: A Bibliometric Perspective, Current Urban Studies, 2016, 4, 36-52

Resilience in Action (October 2016) Early insights into how cities are institutionalizing resilience, Pioneered by Rockefeller Foundation, Online, available at: http://www.100resilientcities.org/ wp-content/uploads/2016/10/Resilience2Oin20Action20100RC20Report200ctober202016. pdf. Retrieved on 29 September 2017

Scherbenske S. L. and Dis, A. T. (2011) Addressing climate change adaptation at the Nordic level. Circumpolar perspectives in global dialogue: social sciences beyond the international polar year. Nordregio contributions to ICASS VII, insert to Nordregio 2011(2). http://www. nordregio.se/en/Metameny/About-Nordregio/ Modules-About-Nordregio/Geographicalscope-we-cover/Norden/Addressing-climatechange-adaptation-at-the-Nordic-level/

[SYKE] Finish Environment Institute (2017) Fiveday weather and flood warnings available in the new service (Press release 2017-02-01). Online, available at: http://www.ymparisto.fi/ en-US/Waters/Fiveday_weather_and_flood_ warnings_avail(41962). Retrieved on 15 May 2017
[SMHI] Swedish Meteorological and Hydrological Institute. New climate projections indicate more extreme weather, Published Sep 16, 2010 and last updated Mar 20, 2017. Online, available at: http://www.smhi.se/en/research/ research-news/new-climate-projectionsindicate-more-extreme-weather-1.12924. Retrieved on 19. April 2017

State of Green (2016): Urban Innovation for Livable Cities. Online, available at: https://stateofgreen.com/files/download/10716. Retrieved on 15 May 2017.

State of Green (February 2017): 12 examples of climate resilient solutions. Online, available at: https://stateofgreen.com/en/profiles/stateof-green/news/12-examples-of-climate-resilient-city-solutions Retrieved on 29 September 2017

Stockholm Stad (Stockholm Municipality) (2017), Stockholm Växer (Stockholm is growing), Slussen. Online, available at: http://vaxer.stockholm.se/projekt/slussen/. Retrieved on 19 April 2017

Stockholm Vatten och Avfal (2017). Stockholm Biochar Project. Online, available at: http:// www.stockholmvattenochavfall.se/en/wasteand-recycling/development/biochar/. Retrieved on 19 April 2017

\section{The Compact Green City}

Braae, E. (2015). Beauty redeemed. Recycling post-industrial landscapes. Basel: Birkhäuser Verlag

Elmqvist, T., Fragkias, M., Goodness, J., Güneralp, B., Marcotullio, P.J., McDonald, R.I., Parnell, S., Schewenius, M., Sendstad, M., Seto, K.C., Wilkinson, C ,eds. (2013). Urbanization, biodiversity and ecosystem services: challenges and opportunities. Springer Dordrecht Heidelberg New York London.

European Commission. (2006). Communication from the Commission to the Council and the European Parliament on thematic strategy on the urban environment. Online, available at: http://www.europarl.europa.eu/sides/getDoc. do?type $=$ TA\&language $=E N \&$ reference $=P 6-$ TA-2006-0367. Retrieved on 27 March 2017.

Fertner, C.; Jørgensen, G.; Nielsen, T. A. S.; Nilsson, K. S.B. (2016). Urban sprawl and growth management - drivers, impacts and responses in selected European and US cities. Future Cities and Environment 2:1-13. 
Haaland, C. and Konijnendijk van den B. C. (2015). Challenges and strategies for urban greenspace planning in cities undergoing densification: A review. Urban Forestry \& Urban Greening 14:760-771.

Niemelä, J., Breuste, J. H., Guntenspergen, G., Mclntyre, N. E., Elmqvist, T., and James, P., eds. (2011). Urban ecology - patterns, processes and applications. Oxford University Press.

Nilsson, K.; Nielsen, T. S.; Aalbers, C.; Bell, S.; Boitier, B.; Chery, J. P.; Fertner, C.; Groschowski, M.; Haase, D.; Loibl, W.; Pauleit, S.; Pintar, M.; Piorr. A.; Ravetz, J.; Ristimäki, M.; Rounsevell, M.; Tosics, I.; Westerink, J. and Zasada, I. (2014). Strategies for sustainable urban development and urban-rural linkages. European Journal for Spatial Development. Online, available at: http://www.nordregio.se/Global/Publications/ Publications\%202017/article_4_Nilsson(2014). pdf , Retrieved on 27 March 2017.

\section{The Mobility City}

[Cebr] Center for Economics and Business Research Exploration (2017): Urban Mobility Index, in collaboration with Qualcomm, April 2017, London.

Copenhagenize Design Company (2017): The Criteria for the Copenhagenize Index. Copenhagen. Online, available at: www.copenhagenize. eu/index/criteria.html. Retrieved on 25 October 2017.

Banister, D. (2008): The sustainable mobility paradigm, Transport policy 15: 73-80.

Booz \& Company (2012): Study on the financing needs in the area of sustainable urban mobility - Final Report, prepared for DG Move, London, March 2012. Online, available at: https:// ec.europa.eu/transport/sites/transport/files/ themes/urban/studies/doc/2012-03-study-onthe-financing-needs-in-the-area-of-sustainable-urban-mobility-final-report.pdf. Retrieved on 23 May 2017.

Hickman, R., Seaborn, C., Headicar, P. \& Banister, D. (2009): Planning for sustainable travel: integrating spatial planning and transport, Association for European Transport and contributors.

Little, A. D. (2014): The Future of Urban Mobility 2.0: imperatives to shape extended mobility ecosystems of tomorrow, January 2014.

Næss, P. (2012): Urban form and travel behavior: experiences from a Nordic context, Journal of Transport and Land Use 5:2 21-45.
Rodrigue, J.P. (2006): The geography of transport systems, 3th edition Routledge.

Swedish ICT AB (2016): Mobility as a service - describing the framework final report on MAAS.

[UITP] International Association of Public Transport (2015): Mobility in Cities database, Synthesis report, June 2015, Brussels. Online, available at: http://www.uitp.org/sites/default/files/ cck-focus-papers-files/MCD_2015_synthesis_ web_O.pdf. Retrieved on 25 October 2017.

\section{The Low-Carbon City}

Calderon, C., Keirstead, J. (2012) Modelling frameworks for delivering low-carbon cities: Advocating a normalized practice. Building Research and Information 4O(4), pp. 504-517.

[EEA] European Environmental Agency (2006) Urban sprawl in Europe. EEA: Copenhagen.

Fujii, M., Fujita, T., Dong, L., Lu, C., Geng, Y., Behera, S.K., Park, H.-S., Chiu, A.S.F. (2016) Possibility of developing low-carbon industries through urban symbiosis in Asian cities. Journal of Cleaner Production Journal of Cleaner Production 114, pp. 376-386

Huisingh, D., Zhang, Z., Moore, J.C., Qiao, Q., Li, Q. (2015) Recent advances in carbon emissions reduction: Policies, technologies, monitoring, assessment and modeling. Journal of Cleaner Production 103, pp. 1-12

[ICLEI] International Council for Local Environmental Initiatives (2017) Low -carbon City website. Online, available at: http://www.iclei. org/activities/agendas/low-carbon-city.html. Retrieved on 3 May 2017.

Lehmann, S. (2012) Can rapid urbanisation ever lead to low carbon cities? the case of Shanghai in comparison to Potsdamer Platz Berlin. Sustainable Cities and Society 3(1), pp. 1-12.

Lund, H., Werner, S., Wiltshire, R., Svendsen, S., Thorsen, J.E., Hvelplund, F. \& Vad Mathiesen, B. (2014) 4th Generation District Heating (4GDH): Integrating smart thermal grids into future sustainable energy systems. Energy: 68: 1-11.

[NER] Nordic Energy Research (2016) Nordic Energy Technology Perspectives 2016. Nordic Energy Research, Oslo, Norway.

Ness, D.A., Xing, K. (2017) Towards a ResourceEfficient Built Environment: A Literature Review and Conceptual Model. Journal of Industrial Ecology, 21 (3), pp. 572-592.

Roberts, D. (2017) Unless we share them, selfdriving vehicles will just make traffic worse. Vox. 
Online, available at: https://www.vox.com/energy-and-environment/2017/5/18/15604744/ self-driving-cars-cities. Retrieved on 24 May 2017

Tan, S., Yang, J., Yan, J., Hashim, H., Chen, B. (2017) A holistic low carbon city indicator framework for sustainable development. Applied Energy 185, pp. 1919-1930.

The City of Gothenburg (2017) DriveME website, available at: https://international.goteborg. se/smart-cities-and-sustainable-solutions/ driveme-self-driving-cars-sustainable-mobility, Accessed: 2017-10-24.

Wang, K., Wei, Y.-M. (2014) China's regional industrial energy efficiency and carbon emissions abatement costs. Applied Energy 130, pp. 617-631.

Yin, K., Wang, R. Zhou, C., Liang, J. (2012) Review of eco-efficiency accounting method and its applications. Shengtai Xuebao/ Acta Ecologica Sinicia, 32 (11) pp. 3595-3605.

\section{The Circular Economy City}

[Ademe] Agence de l'Environnement et de la Maitrise de l'Energie (2016) White Paper on the Circular Economy of Greater Paris. Online, available at: https://api-site.paris.fr/images/77050. Retrieved on 20 September 2017

[ASM] Amsterdam Smart City (2017) Circular

City. Online, available at: https://amsterdamsmartcity.com/themes/circular-city. Retrieved on 20 September 2017

[CE Force] Cities cooperating FOR Circular Economy (2016) Horizon 2020 Framework Programme. Online, available at: http://www. ce-force.eu/. Retrieved on 22 September 2017.

City of Paris (2015) White Paper on the circular economy of Greater Paris.

[EMF] Ellen MacArthur Foundation (2015) Potential for Denmark as a Circular Economy. A case study from: Delivering the circular economy - a toolkit for policy makers. https://www.ellenmacarthurfoundation.org/assets/downloads/ government/20151113_DenmarkCaseStudy. pdf. Retrieved on 20 September 2017.

[EMF] Ellen MacArthur Foundation, SUN and McKinsey Center for Business and Environment (2015) Growth Within: a circular economy vision for a competitive Europe. Online, available at: https://www.ellenmacarthurfoundation. org/assets/downloads/publications/EllenMacArthurFoundation_Growth-Within_July15.pdf.
Retrieved on 20 September 2017.

[EMF] Ellen MacArthur Foundation (2016) Circu-

lar Cities Network. Online, available at: https:// www.ellenmacarthurfoundation.org/programmes/government/circular-cities-network, retrieved on 21 September 2017.

[EMF] Ellen MacArthur Foundation (2017) Cities in the Circular Economy: An Initial Exploration. Online available at: https://www.ellenmacarthurfoundation.org/assets/downloads/publications/Cities-in-the-CE_An-Initial-Exploration.pdf, Retrieved on 20 September 2017.

[EC] European Commission (2016) Urban Agenda for the EU. Online, available at: https:// ec.europa.eu/futurium/en/urban-agenda. Retrieved on 20 September 2017

Geng, Y., Qinghua Z., Brent D., and Tsuyoshi F. (2009). Implementing China's circular economy concept at the regional level: a review of progress in Dalian, China. Waste Management 29, no. 2: 996-1002.

Greater Copenhagen (2017) Circular Economy / Competence Catalogue. Online, available at: https://www.regionh.dk/cpheuoffice/Documents/170629_COP_kompetencekatalog_final. pdf. Retrieved on 21 September 2017.

Guangzhou Award (2017) Tampere, Finland: Model of the Best Regional Circular Economy Concept for Cities, Companies and Citizens. Online available at: http://www.guangzhouaward.org/en/2017-03/27/c_72613.htm. Retrieved on 21 September 2017.

[ICLEI] International Council for Local Environmental Initiatives (2016) Five forward-thinking cities and regions receive the Guangzhou International Award for Urban Innovation. Online available at: http://www.iclei.org/details/ article/five-cities-and-regions-receive-theguangzhou-international-award-for-urban-innovation.html. Retrieved on 21 September 2017.

Lindner, P., Mooij, C. and Rogers, H. (2017) Circular Economy in Cities: A Strategic Approach Towards a Sustainable Society? Master's Degree Thesis. Blekinge Institute of Technology, Karlskrona, Sweden

[LWARB] London Waste and Recycling Board (2015) London's Circular Economy Route Map. Online available at: http://www.Iwarb. gov.uk/wp-content/uploads/2015/04/ LWARB-London\%E2\%80\%99s-CE-routemap_16.6.17a_singlepages_sml.pdf. Retrieved on 22 September 2017. 
[NCM] Nordic Council of Ministers (2015) Moving towards a circular economy - successful Nordic business models. Policy brief

Prendeville, S., Cherim, E., Bocken, N. (2017) Circular Cities: Mapping Six Cities in Transition. Environmental Innovation and Societal Transitions, https://doi.org/10.1016/j.eist.2017.03.002

Resource (2016) London to collaborate with European capitals in circular economy drive, 4 May 2016. Online, available at http://resource.co/ article/london-collaborate-european-capitalscircular-economy-drive-10927 Retrieved on 5 June 2017

Schor, J. (2016). Debating the sharing economy. Journal of Self-Governance and Management Economics, 4(3), 7-22.

Sitra (2017) Cities lead the way to a circular economy. Online, available at: https://www.sitra.fi/ en/articles/cities-lead-way-circular-economy/. Retrieved on 22 September 2017.

Stahel, W. R. (2010) The Performance Economy, Palgrave Macmillan 2010

Stockholm vatten och avfall (2017). Online, available at http://www.stockholmvattenochavfall. se/en/waste-and-recycling/development/biochar/. Retrieved on 5 June 2017

The Guardian (2016) Waste not want not: Sweden to give tax breaks for repairs. Online, available at https://www.theguardian.com/ world/2016/sep/19/waste-not-want-not-sweden-tax-breaks-repairs. Retrieved on 12 May 2017

URBACT (2016) Circular economy: another buzzword or your city's future? Online, available at: http://urbact.eu/circular-economy-anotherbuzzword-or-your-city\%E2\%80\%99s-future. Retrieved on 12 June, 2017

[VEC] Vancouver Economic Commission (2016) Creating a circular economy in Vancouver through government action. Online, available at: http://www.vancouvereconomic.com/blog/ vecs_take/creating-a-circular-economy-in-vancouver-through-government-action/. Retrieved on 22 September 2017.

Wijkman, A. and Skånberg, K. (2016) The Circular Economy and Benefits for Society Jobs and Climate Clear Winners in an Economy Based on Renewable Energy and Resource Efficiency. A study pertaining to Finland, France, the Netherlands, Spain and Sweden. The Club of Rome 2016.

\section{The Smart City}

Cocchia, A. (2014). Smart and digital city: A systematic literature review. In Smart city (pp. 13-43). Springer International Publishing.

D'Auria, A., Tregua, M. and Bifulco, F. (2014). Digital City towards Smart City: a theoretical overview. Conference: 2nd International Virtual Scientific Conference (SCIECONF), ISSN: 1339-3561. Online available at: https://www. researchgate.net/publication/298201516_Digital_City_towards_Smart_City_a_theoretical_ overview. Retrieved on 22 September 2017.

Demos Helsinki (2016). Nordic Cities Beyond Digital Disruption - a novel way to develop cities. Demos Helsinki \& KTH 2016. Online, available at: http://www.demoshelsinki.fi/en/ julkaisut/nordic-cities-beyond-digital-disruption/. Retrieved on 16 May, 2017.

European Commission (2017). The Digital Economy and Society Index (DESI). Online, available at: https://ec.europa.eu/digital-single-market/en/ desi. Retrieved on 10 May 2017.

Helsinki loves developers: https://dev.hel.fi/

Ragnedda, M., and Muschert, G. W. (2013). The digital divide: The Internet and social inequality in international perspective (Vol. 73). Routledge.

TEKES 2016. Smart Solutions from Finland Concepts, products, and services that make your life easier. Online, available at: https://www. tekes.fi/globalassets/julkaisut/tekes_smartsolutions.pdf. Retrieved on 5 May 2017.

TEKES 2015. Smart Solutions From Finland. Online, available at: https://www.tekes.fi/ globalassets/global/ohjelmat-ja-palvelut/ ohjelmat/fiksu-kaupunki/smart-solutionsfrom-finland.pdf. Retrieved on 5 May 2017.

Svensk byggtjänst 2016. This is My Blocks. Online, accessed via: [https://byggtjanst.se/aktuellt/ mina-kvarter/english-summary/] - Retrieved on 22 May 2017.

\section{The Design City}

Arkitekturmuseet (1980). Funktionalismens genombrott och kris: svenskt bostadsbyggande 1930-80: [utställning utförd av Arkitekturmuseet ...]. Stockholm: Arkitekturmuseet.

Björk, E. (2014) "A Nordic charter for universal design." Scandinavian Journal of Social Medicine 42.11-6.

Boys, J. (2014) Doing disability differently: an alternative handbook on architecture, dis/abil- 
ity and designing for everyday life, London: Routledge.

Congress for the New Urbanism (1996) "Charter of the New Urbanism", in Larice, Michael \& Macdonald, Elizabeth (eds) (2013) The urban design reader, London: Routledge

Curedale, R. (2016) Design thinking: process \& methods guide, Topanga, CA: Design Community College.

Design för all Sverige, www.designforalla.se

Ehrnberger, K. (2017) Tillblivelser: En trasslig berättelse om design som normkritisk praktik, Stockholm: KTH Royal Institute of Technology.

Engfors, C. (red.) (1987). Folkhemmets bostäder 1940-1960: [svenskt bostadsbyggande under 1940- och 50-talen]. Stockholm: Arkitekturmuseet.

Fallan, K. (red.) (2012). Scandinavian design: alternative histories. London: Berg

Grillner, K. (2013) "Design Research and Critical Transformations: Situating Thought, Projecting Action", in Fraser, Murray (ed) (2013) Design Research in Architecture: An Overview, Farnham, Surrey: Ashgate.

Houze, R. (2010) "Introduction", in Lees-Maffei, Grace \& Houze, Rebecca (2010) The design history reader, New York: Berg Publishers, 2010

Larice, M. and Macdonald, E. (eds) (2013) The urban design reader, London: Routledge.

Laurel, B. (2003) Design research: methods and perspectives, Cambridge, MA: MIT Press.

Lydon, M. and Garcia, A. (2015) Tactical urbanism: short-term action for long-term change, Washington, DC: Island press.

Mitchell, D. (2003) The right to the city: social justice and the fight for public space, New York: Guilford Press.
Moultrie, J. \& Livesey, F. (2009) International Design Scoreboard: Initial indicators of international design capabilities, Design Council.

Power, D. (2005) The Future in Design-the competitiveness and industrial dynamics of the Nordic design industry, Nordic Council of Ministers. Online, available at: http://nordicinnovation.org/Global/_Publications/Reports/2005/ The\%20Future\%20in\%20Design\%20-\%20 the $\% 20$ competitiveness $\% 20$ and $\% 20$ industrial\%20dynamics\%20of\%20the\%20Nordic\%20 design\%2Oindustry.pdf. Retrieved on 3 May 2017

Power, D., Johan J. and Mark L. (2006) "Nordic design for a global market: policies for developing the design industry in the Nordic Region", Nordic Council of Ministers. Online, available at: http://www.ico-d.org/database/files/library/nordic.pdf. Retrieved on 3 May 2017

Saarikangas, K. (2002) Asunnon muodonmuutoksia: puhtauden estetiikka ja sukupuoli modernissa arkkitehtuurissa, Helsinki Suomalaisen kirjallisuuden seura.

Skou, N. P. and Munch, A. V. (2016) New Nordic and Scandinavian Retro: reassessment of values and aesthetics in contemporary Nordic design. Journal of Aesthetics \& Culture, 8 (1).

Waldheim, C. (2006) "Landscape as Urbanism", in Larice, Michael \& Macdonald, Elizabeth (eds) (2013) The urban design reader, London: Routledge

Zukin, S. (2010) Naked city: the death and life of authentic urban places, Oxford: Oxford University Press. 


\section{Appendix 1}

\section{List of interviewees and participants in the focus groups}

\begin{tabular}{|c|c|c|c|c|c|c|}
\hline Denmark & Finland & Iceland & Sweden & Norway & Greenland & $\begin{array}{l}\text { Other } \\
\text { countries }\end{array}$ \\
\hline $\begin{array}{l}\text { Neel Strøbæk, } \\
\text { Civil and } \\
\text { Structural } \\
\text { Eng., Group } \\
\text { Market } \\
\text { Director at } \\
\text { Rambøll }\end{array}$ & $\begin{array}{l}\text { Anni } \\
\text { Sinnemäki, } \\
\text { Deputy Mayor } \\
\text { of Real Estate } \\
\text { and City } \\
\text { Planning at } \\
\text { City of Helsinki }\end{array}$ & $\begin{array}{l}\text { Sverrir } \\
\text { Bollason, } \\
\text { Environment } \\
\text { and Planning } \\
\text { at VSO } \\
\text { Consulting }\end{array}$ & $\begin{array}{l}\text { Jonas Törnblom, } \\
\text { Director of } \\
\text { Marketing and } \\
\text { Communications } \\
\text { at Envac Group } \\
\text { AB }\end{array}$ & $\begin{array}{l}\text { Herbjørn } \\
\text { Tjeltveit, } \\
\text { CEO at Nordic } \\
\text { Edge }\end{array}$ & $\begin{array}{l}\text { Mats Hjerpe, } \\
\text { Director of } \\
\text { the Nordic } \\
\text { Institute in } \\
\text { Greenland }\end{array}$ & $\begin{array}{l}\text { Giselher } \\
\text { Shultz- } \\
\text { Berndt, } \\
\text { Managing } \\
\text { Director of } \\
\text { HafenCity, } \\
\text { Hamburg, } \\
\text { Germany }\end{array}$ \\
\hline $\begin{array}{l}\text { Anna Louise } \\
\text { Højbjerg } \\
\text { Henrichsen, } \\
\text { Public Affairs } \\
\text { Manager at } \\
\text { Danfoss }\end{array}$ & $\begin{array}{l}\text { Juha } \\
\text { Kostiainen, } \\
\text { Senior Vice } \\
\text { President, } \\
\text { Sustainable } \\
\text { Urban } \\
\text { Development } \\
\text { at YIT } \\
\text { Corporation } \\
\text { - YIT - } \\
\text { Building and } \\
\text { Construction } \\
\text { Company }\end{array}$ & $\begin{array}{l}\text { Ólöf } \\
\text { Örvarsdóttir, } \\
\text { Head of } \\
\text { Division, } \\
\text { Reykjavik } \\
\text { Environmental } \\
\text { and Planning } \\
\text { Department, } \\
\text { Reykjavik City }\end{array}$ & $\begin{array}{l}\text { Östen Ekengren, } \\
\text { Vice General } \\
\text { Manager at } \\
\text { IVL - Svenska } \\
\text { Miljöinstitutet } \\
\text { (Swedish } \\
\text { Environment } \\
\text { Research } \\
\text { Institute) }\end{array}$ & $\begin{array}{l}\text { Frode Vattum, } \\
\text { Head of } \\
\text { Strategy for } \\
\text { Oslo's public } \\
\text { transport } \\
\text { authority Ruter }\end{array}$ & & $\begin{array}{l}\text { Larry Beasley } \\
\text { Professor } \\
\text { of Planning, } \\
\text { University } \\
\text { of British } \\
\text { Columbia. } \\
\text { Former Co- } \\
\text { Director of } \\
\text { Planning for } \\
\text { the City of } \\
\text { Vancouver - } \\
\text { Canada }\end{array}$ \\
\hline $\begin{array}{l}\text { Tina Saaby, } \\
\text { Chief City } \\
\text { Architect at } \\
\text { Copenhagen } \\
\text { Municipality }\end{array}$ & $\begin{array}{l}\text { Kari Kankaala, } \\
\text { Director of } \\
\text { Economic } \\
\text { and Urban } \\
\text { Development } \\
\text { with the City of } \\
\text { Tampere }\end{array}$ & & $\begin{array}{l}\text { Anders Sundvall, } \\
\text { Executive Direc- } \\
\text { tor of Environ- } \\
\text { mentally-driv- } \\
\text { en Business } \\
\text { Development at } \\
\text { Dalarna Science } \\
\text { Park } \\
\text { Asset (Associa- } \\
\text { tion of Swedish } \\
\text { Environment } \\
\text { Technology) }\end{array}$ & $\begin{array}{l}\text { Tor Inge } \\
\text { Hjemdal, } \\
\text { Director of } \\
\text { Architecture } \\
\text { at Design and } \\
\text { Architecture } \\
\text { Norway - } \\
\text { DogA }\end{array}$ & & \\
\hline $\begin{array}{l}\text { Klaus Lehn } \\
\text { Christensen, } \\
\text { Danish } \\
\text { Cleantech Hub, } \\
\text { NYC }\end{array}$ & $\begin{array}{l}\text { Kari Tuukkanen, } \\
\text { Business Area } \\
\text { Director, Digital } \\
\text { Services at } \\
\text { SITO }\end{array}$ & & $\begin{array}{l}\text { Göran Cars, City } \\
\text { Developer at } \\
\text { Kiruna Kommun }\end{array}$ & $\begin{array}{l}\text { Rainer Stange, } \\
\text { Partner/ } \\
\text { Professor/ } \\
\text { Landskaps- } \\
\text { arkitekt MNLA, } \\
\text { DRONNINGA } \\
\text { LANDSKAP }\end{array}$ & & \\
\hline $\begin{array}{l}\text { Holger } \\
\text { Bisgaard, } \\
\text { Nature Agency } \\
\text { (Naturstyrelsen) }\end{array}$ & $\begin{array}{l}\text { Karin Wikman, } \\
\text { Programme } \\
\text { Director of } \\
\text { the Witty City } \\
\text { Smart Cities at } \\
\text { Tekes (Finnish } \\
\text { Innovation } \\
\text { Agency) }\end{array}$ & & $\begin{array}{l}\text { Lars Marcus, } \\
\text { Professor of } \\
\text { Urban Design } \\
\text { and Planning } \\
\text { at Chalmers } \\
\text { University in } \\
\text { Gothenburg }\end{array}$ & $\begin{array}{l}\text { Tonje Værdal } \\
\text { Frydenlund, } \\
\text { Managing } \\
\text { Director at } \\
\text { Snøhetta }\end{array}$ & & \\
\hline
\end{tabular}




\begin{tabular}{|l|l|l|l|l|l|l|l|l|} 
Denmark & Finland & Iceland & Sweden & Norway & Greenland \\
countries
\end{tabular}

Continued.

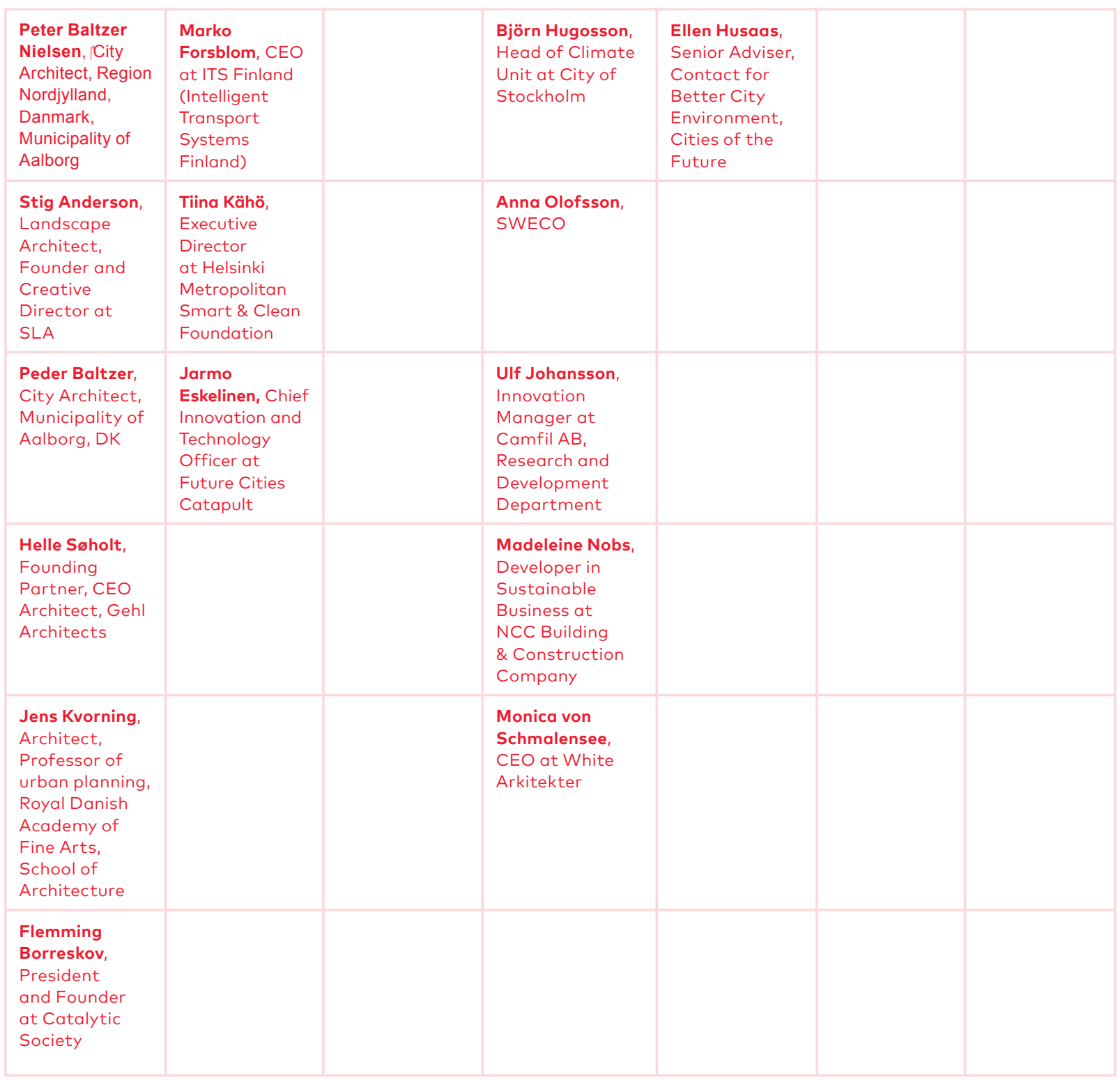




\section{Nordic City Network - NCN}

- Christer Larsson, Chairman,

- Per Riisom, Director

- Hannah Wadman, Head of Secretary

- Henrik Poulsen, Analyst and communicator

- Uffe Steiner Jensen, Political Advisor

- Louise Vogel Kielgast, Member Network Secretary

- Eva Engquist, Member Network Secretary

- Jerry Lanka, Intern

\section{Nordic Built Cities - Jury Members}

- Flemming Borreskov, President and founder at Catalytic Society, Denmark

- Birita Wardum, City architect at Tórshavnar kommuna, Faroe Islands

- Jarmo Eskelinen, CEO of Forum Virium Helsinki, Finland

- Hanna Rehling, Planner at at Orbicon, Greenland
- Anna Maria Bogadottir, Architect FAÍ at ÚRBANISTAN, Iceland

- Rainer Stange, Landscape architect and partner, Dronninga Landskap, Norway

- Peter Örn, Independent management consulting professional, Sweden

- Larry Beasley, Former Co-Director of Planning for the City of Vancouver, Canada

- Gieselher Schultz-Berndt, Managing Director of HafenCity, Hamburg, Germany

\section{Branding representatives from the Nordic Region}

- Homanen Ilkka, FinPro, Finland

- Andri Marteinsson, Promote Iceland, Iceland

- Anette Brænder, State of Green, Denmark

- Annie Ross, Business Sweden, Sweden

- Oscar Kipperberg, Innovation Norway, Norway 


\section{Appendix 2}

\section{Questionnaire used during the workshops and phone interviews Interview about Nordic city characteristics and qualities:}

We are interested in your knowledge and reflections about sustainable urban development in the Nordic countries: Nordic qualities, policies and cases.

1. First, if you were to tell a non-Nordic visitor a story about the most important characteristics/ qualities of Nordic cities, what would you emphasize? What are the main characteristics and qualities of a Nordic city? (any particular characteristics in the built environment/urban life/mobility, etc.)

2. What are the preconditions for these characteristics and qualities? The central planning tools, policies, values, ways of doing things, etc., that result in "the Nordic city"? (For example, these could be a planning system that invites citizen participation, an innovative energy sector, strong advocacy for public transportation, active lobbyists for disability issues, a municipal planning monopoly, distributive regional policy, etc.)
3. Do you see these preconditions as possible export goods to other countries? If so, what could be exported? Is it already happening? (Q3 leads over to Q4, about cases, examples, etc.)

4. Where do we find the best showcases of Nordic good practice in the Nordic countries as well as abroad? Could you give examples of places, planning cases, innovations, companies, products, etc., that you think embody or practice the values of "Nordic cities" that we have discussed, or that are good examples of urban development in the Nordic context, representing good Nordic urban development practice?

5. Are you familiar with any existing collaborations between Nordic cities and cities in China, India or the U.S.? Existing networks? Successful export products?

6. Are there any other issues that should be included in this story? 




\section{(11) Nordregio}

P.O. Box 1658

SE-111 86 Stockholm, Sweden

nordregio@nordregio.org

www.nordregio.org

www.norden.org 